\title{
BIRD NUMBER DYNAMICS DURING THE POST-BREEDING PERIOD AT THE TÖMÖRD BIRD RINGING STATION, WESTERN HUNGARY
}

\author{
József Gyurácz ${ }^{*}$, Péter Bánhidi², József Góczán², \\ Péter Illés ${ }^{2}$, Sándor Kalmár ${ }^{2}$, Péter Koszorús ${ }^{2}$, Zoltán Lukács ${ }^{1}$, \\ Csaba Németh², László Varga ${ }^{2}$
}

\begin{abstract}
Gyurácz J., Bánhidi P., Góczán J., Illés P., Kalmár S., Koszorús P., Lukács Z., Németh C. and Varga L. 2017. Bird number dynamics during the post-breeding period at the Tömörd Bird Ringing Station, western Hungary. Ring 39: 23-82.

The fieldwork, i.e. catching and ringing birds using mist-nets, was conducted at Tömörd Bird Ringing Station in western Hungary during the post-breeding migration seasons in 1998-2016. Altogether, 106,480 individuals of 133 species were ringed at the station. The aim of this paper was to publish basic information on passerine migration at this site. Migration phenology was described through annual and daily capture frequencies. Furthermore, we provide the median date of the passage, the date of the earliest or latest capture, the peak migration season within the study period, and the countries where the birds monitored at the site were ringed or recovered abroad. To compare the catching dynamics for the fifty species with total captures greater than 200, a reference period was defined: from 5 Aug. to 5 Nov. 2001-2016. Some non-passerines that are more easily caught with mist-nets or that are caught occasionally were listed as well. The two superdominant species, the European Robin and the Eurasian Blackcap, with 14,377 and 13,926 total captures, made up $27 \%$ of all ringed individuals. Among the fifty species analysed, there were ten species with a decreasing trend, five species with an increasing trend and thirty-five species with a stable (or uncertain) trend in their numbers from 2001 to 2016. The temporal pattern of migration of long-distance migrants was different from that of the mediumand short-distance migratory species.
\end{abstract}

${ }^{1}$ University of Eötvös Lorand, Savaria Department of Biology, Szombathely, Károlyi Gáspár tér 4. H-9700, Hungary.

${ }^{2}$ Local Group of BirdLife Hungary, Szombathely, Károlyi Gáspár tér 4. H-9700, Hungary

*Corresponding author: Gyuracz J. - gyuracz.jozsef@sek.elte.hu

Keywords: bird migration, migration dynamics, passerines, autumn, western Hungary 


\section{INTRODUCTION}

Bird migration is one of the most exciting phenomena in our living world, so it is not surprising that it has been the subject of investigation since ancient times. Each year an estimated 50,000 million birds travel throughout the world. Short-distance migrants may only leave their mountainous breeding areas to seek milder winter conditions in the nearby foothills, while long-distance migrants often cover tens of thousands of kilometres (Alerstam 1990). The principal migratory routes for many species of passerines migrating from Europe to African wintering sites are fairly well known. What is missing is a detailed analysis of the environmental factors controlling bird migration and the temporal and spatial course of the migratory journeys (Bairlein 1997, Tieleman 2007).

Palearctic-African migratory bird populations must overcome several ecological barriers, such as seas and deserts, during their migration in the post-breeding season and spring. Migration dynamics involve evolution of the timing as well as the number and duration of stopovers for feeding or resting (Berthold 1993, Berthold et al. 2003, Rappole and Jones 2002).

Many European bird species are currently undergoing rapid declines, but some increasing and expansive populations (BirdLife 2017). The causes of these changes are not clear, but factors such as habitat fragmentation, agricultural technology, hunting, and global climate change are known to be seriously affecting certain European bird populations (op. cit.). Monitoring is essential for identification of ecological and conservation problems affecting birds. According to the EC Birds Directive on the protection of European bird populations, all European Community countries are required to monitor bird populations. In Annex V of the directive, specific reference is made to the use of bird ringing to monitor population levels of migratory bird species. Birds are particularly good subjects for population monitoring because they are sensitive indicators of habitat changes.

Annual counts of birds tell us how numbers are changing, but bird ringing is needed if we want to understand the mechanism of the changes observed. Various types of useful information can be recorded when birds are caught for ringing. These include the age and sex of the individual, a variety of measurements which can be used to characterize different populations, the amount of fat stored by migratory birds, the state of feather moult, and the habitat in which the species was captured. Single birds can be recaptured by other ringers, resighted or recovered by members of the public in a variety of ways: hit by cars, found dead, caught by a cat, shot, etc. If a bird is subsequently recaptured by other ringers, repeated measurements can be used to study various aspects of the annual life cycle, such as changes in body mass prior to migration or the seasonal progression of moult (Newton 2011).

The National Ringing Centres collect all information provided by ringers and members of the public who have found ringed birds. The Hungarian Ringing Centre of BirdLife Hungary is located in Budapest. Bird ringing for scientific purposes began in Hungary in 1908, when Jakab Vönöczky-Schenk released White Storks (Ciconia ciconia) that 
had been ringed with metal rings engraved with numbers. Bird ringing and bird migration studies in particular were revolutionized in the mid-20th century, when mistnets became generally available. Mist-nets placed beside suitable vegetation easily capture passerines. BirdLife Hungary began a project called 'Actio Hungarica' (AH) for investigation of bird migration in 1974 (Szentendrey et al. 1979). Actio Hungarica has been involved in the netting of migrating songbirds in a network of bird ringing camps in Hungary. The netting effort was strictly standardized and the habitat was managed so as to remain stable, so changes in the numbers of birds captured should reflect changes in the migrating populations.

Bird ringing has been carried out in Hungary throughout the twentieth century. As a result, long-term recovery and biometrical data for birds became one of the most valuable sets of information available for any group of animals (Csörgő et al. 2009). Despite all of this ringing activity, many problems still remain unsolved, and new ones have recently emerged. For instance, due to global climate change - the past decade has been the warmest for 1,000 years - we are confronted with so many rapid changes in bird migration that it is difficult to keep up with recording and analysing them (Pearce-Higgins and Green 2014). The Tömörd Bird Ringing Station was founded in 1998 and joined Actio Hungarica (Gyurácz and Bánhidi 2008) and the South-East European Bird Migration Network (SEEN), which focuses its efforts on the little-researched SE flyway (Busse and Meissner 2015).

The annual field work is divided into the following three time periods: one week at the end of March and early April; a Constant Effort Site programme from mid-April to mid-July; and the autumn migration period from the end of July or early August to early November. Results from the first nine years of the station's work (1998-2007) have been presented in a book by Gyurácz and Bánhidi (2008). The current publication contains the data from the entire time-span of the autumn migration studies within the Bird Ringing Project of Tömörd Bird Ringing Station. A total of 106,480 individuals of 133 species were ringed. The main aspects of the analysis were as follows:

1. To register annual changes in migrating population size and analyse their trends.

2. To describe the progress of the post-breeding movement by analysing daily capture data.

3. To reveal the origin, migration direction and wintering sites of migratory populations recorded at the study site by distribution analysis of recoveries.

\section{STUDY AREA AND METHODS}

\section{Study site and field work}

The birds were captured and ringed at Tömörd Bird Ringing Station $\left(47^{\circ} 21^{\prime} \mathrm{N}\right.$ $\left.16^{\circ} 40^{\prime} \mathrm{E}\right)$ in western Hungary. Tömörd is a small village in Vas County located 15 kilometres from Szombathely (Fig. 1).

Bird ringing was conducted during autumn migration, from the end of July or early August to the end of October or early November (Table 1). 


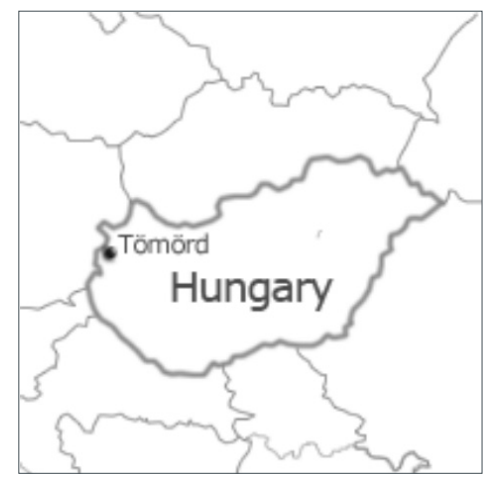

Fig. 1. Location of Tömörd Bird Ringing Station in Hungary (Figure is from the website of the SEEN)

Table 1

Ringing activity periods at the Tömörd Bird Ringing Station

\begin{tabular}{|c|c|c|}
\hline Year & From & To \\
\hline 1998 & 10 Aug. (16 Oct.) & 20 Sep. (31 Oct.) \\
\hline 1999 & 22 Aug. & 31 Oct. \\
\hline 2000 & 20 Aug. & 19 Nov. \\
\hline 2001 & 5 Aug. & 10 Nov. \\
\hline 2002 & 28 Jul. & 9 Nov. \\
\hline 2003 & 27 Jul. & 9 Nov. \\
\hline 2004 & 1 Aug. & 6 Nov. \\
\hline 2005 & 1 Aug. & 11 Nov. \\
\hline 2006 & 29 Jul. & 11 Nov. \\
\hline 2007 & 30 Jul. & 7 Nov. \\
\hline 2008 & 26. Jul. & 7 Nov. \\
\hline 2009 & 2 Aug. & 6 Nov. \\
\hline 2010 & 1 Aug. & 4 Nov. \\
\hline 2011 & 31 Jul. & 3 Nov. \\
\hline 2012 & 29 Jul. & 8 Nov. \\
\hline 2013 & 27 Jul. & 8 Nov. \\
\hline 2014 & 3 Aug. & 5 Nov. \\
\hline 2015 & 2 Aug. & 31 Jul. \\
\hline 2016 & &
\end{tabular}

For bird catching, 28 numbered mist-nets (12 metres long and 2.5 metres high with 5 shelves and $16 \mathrm{~mm}$ mesh size) were used, but occasionally, particularly in August, some birds of prey were caught by cube-net. The location and number of mist-nets were fixed from 1998 to 2016 . The nets were placed in four different habitat types around the ringing station (Fig. 2 and Fig. 3).

Forest (habitat code after Busse and Meissner 2015: W.LB6N0.2EUPR.N.). Trees and bushes 6-9 m high made up compact, dense edge vegetation. This is an ecotone community with turkey oak (Quercus cerris) as a characteristic plant. There are abun- 
dant crops and normal forestry management in the forest. There were 4 nets in this habitat (Photo 1).

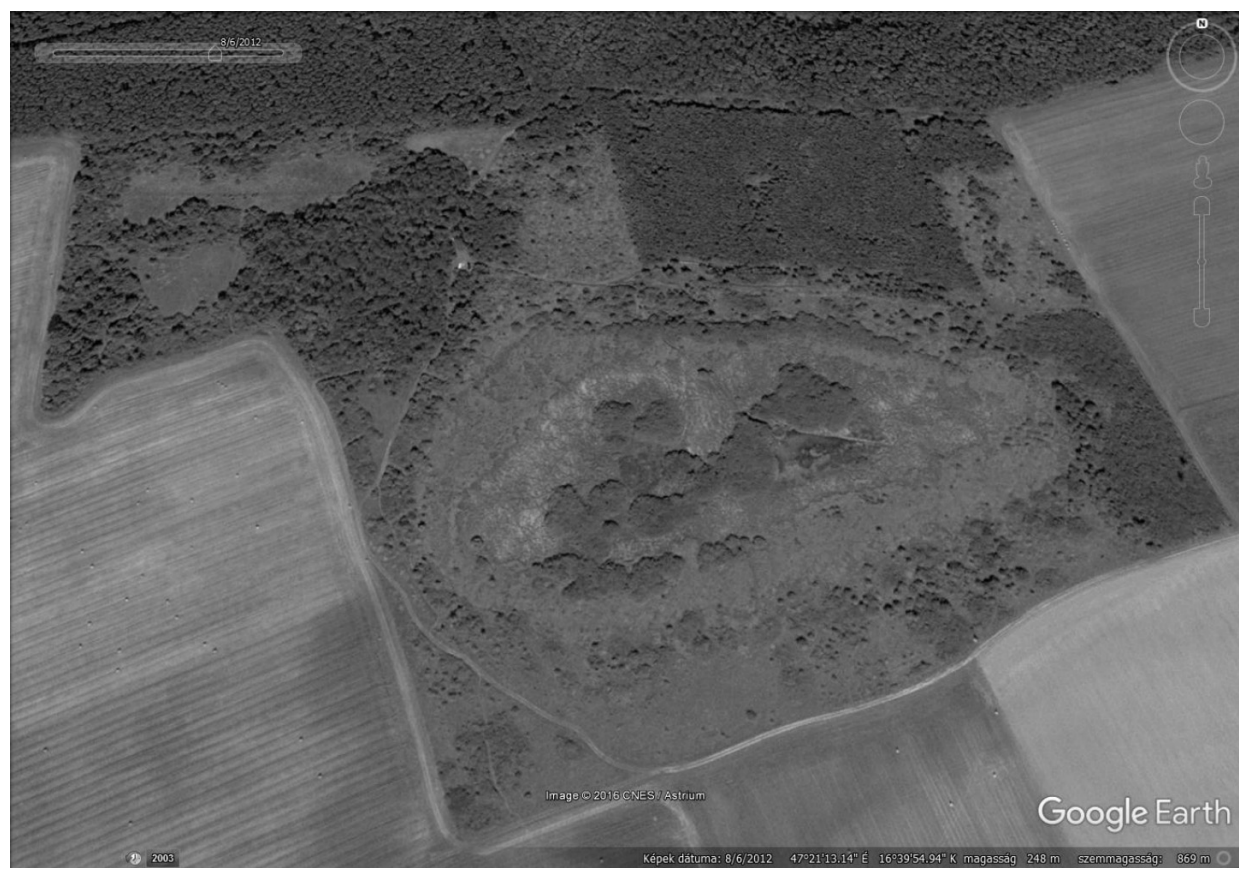

Fig. 2. The study area of Tömörd Bird Ringing Station

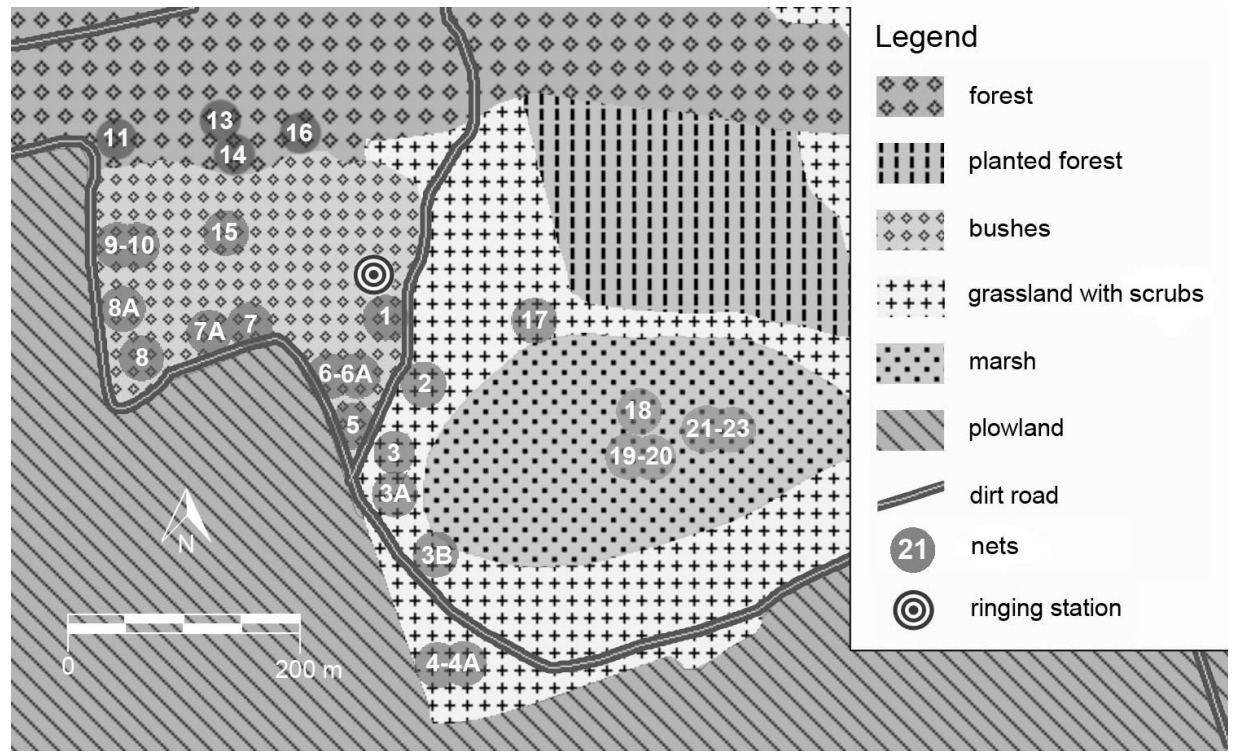

Fig. 3. Habitat map of the study area with the locations of mist-nets 
Bushy (S.BH2N0.2PRCR.O.). Bushes 2-3 m high made up compact, dense vegetation, which was dissected by small grass patches. Its characteristic plant was the blackthorn (Prunus spinosa). There were 11 nets in this biotope (Photo 2).

Grassland with scrubs (S.BG2N9.1ROCA.O.). This was a transition between the wet biotopes of the swamp and the steppe communities that used to cover the cropland. There were few bushes in the grassland in the early years, but their number and cover have increased significantly in recent years. There were a few bushes in the grassland with two small patches of dwarf elder (Sambucus ebulus). The grassland was not managed. There were 7 nets in this biotope (Photo 3 ).

Marsh (S.TC1S0.0.R.). This was a small (6 ha) permanent and isolated wetland. It was dried out in 2000 and 2001. The peaty bottom of the marsh was removed completely in winter 2001. From 2002, rainwater began to accumulate there again and marsh vegetation reappeared in 2003. There was $0.5-1$ ha of open water in the following years. The characteristic plant in the marsh was reedmace (Typha latifolia). A line of 6 nets was placed in this site (Photo 4).

All birds were ringed, aged and sexed according to Svensson (1992). Biometric measurements were taken using the methods of Actio Hungarica (Szentendrey et al. 1979). All birds were weighed to the nearest $0.1 \mathrm{~g}$ (using a spring and digital balance). Wing length was measured to the nearest $1 \mathrm{~mm}$. Fat reserves were estimated visually according to Busse and Meissner (2015), on a scale from 0 (no fat) to 8 (bulging fat).

\section{Data processing and statistical analysis}

As the time of the fieldwork differed between the seasons, the annual and daily captures in the period of 1998-2000 were not suitable for statistical comparisons with data relating to more recent years, but they are essential for determining the number of bird species and individual birds ringed in the station. To compare the catching dynamics for fifty species with total captures greater than 200, a reference period was defined, from 5 Aug. to 5 Nov. 2001-2016. The total annual capture of the first year (2001) was set as 100 percent and the population index of change in captures was calculated by the following formula (Greenwood et al. 1993):

$$
I x=\frac{N x}{N x-1} \cdot I x-1
$$

where $\mathrm{Ix}$ is the chain index of the year in question, $\mathrm{I}_{\mathrm{x}-1}$ is the chain index of the previous year, $\mathrm{N}_{\mathrm{x}}$ is the annual number of captures of the species in the year in question, and $\mathrm{N}_{\mathrm{x}-1}$ is the annual number of captures of the species in the previous year (Appendices $I$ and II). The General Linear Model (GLM) was used to determine trends in the chain index rates and the Past computer program was used for the statistical analysis (Hammer et al. 2001).

Migration curves for the species were calculated based on the total daily captures in the years 2001-2016, smoothed by a 5-day moving average (Appendix III). Based on this information the peak migration period (when we captured the largest number of birds in that season), the date of the earliest or latest capture, and the median passage date were identified. We have reported the countries where birds were ringed and later recovered in Tömörd, as well as the countries where birds ringed in Tömörd were later recovered (Fig. 4). 


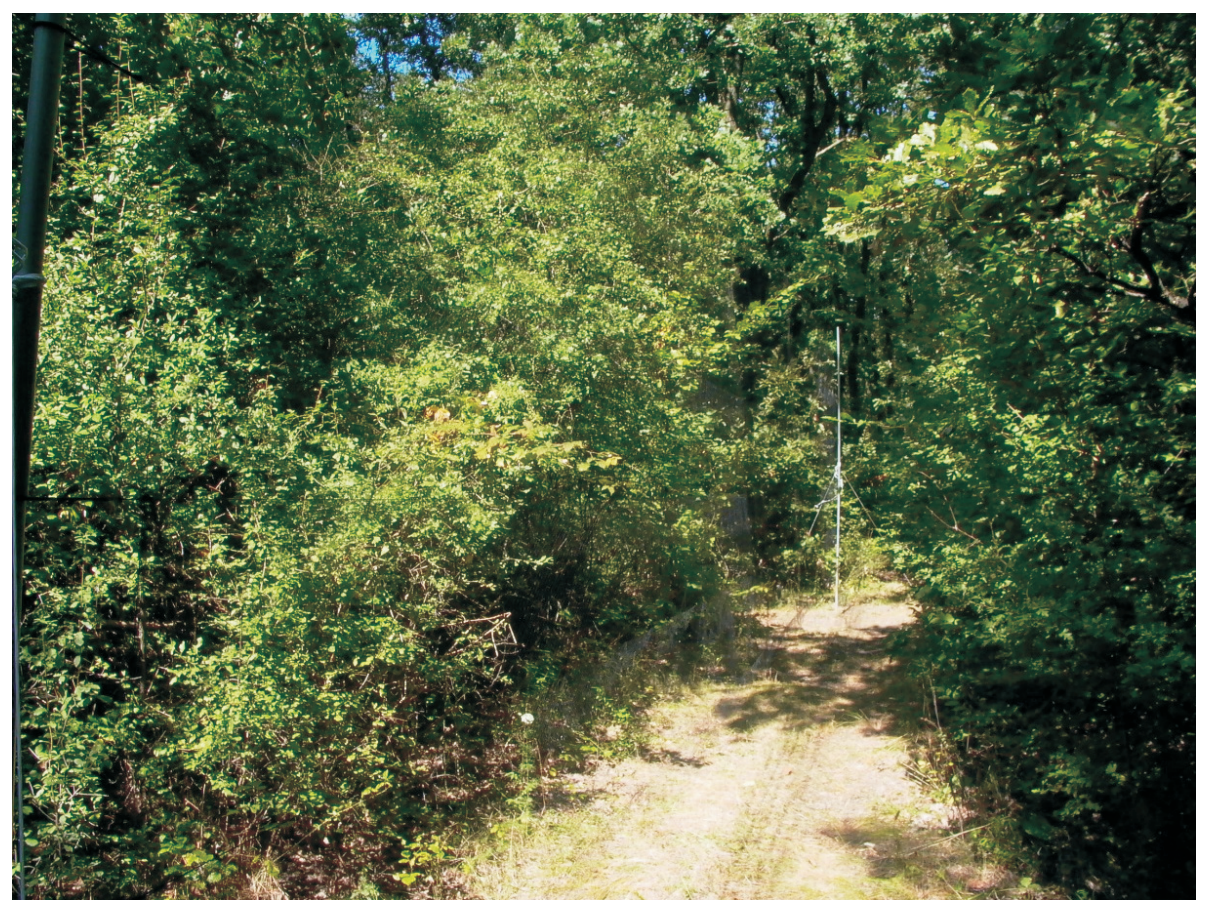

Photo 1. Mist-net in the forest

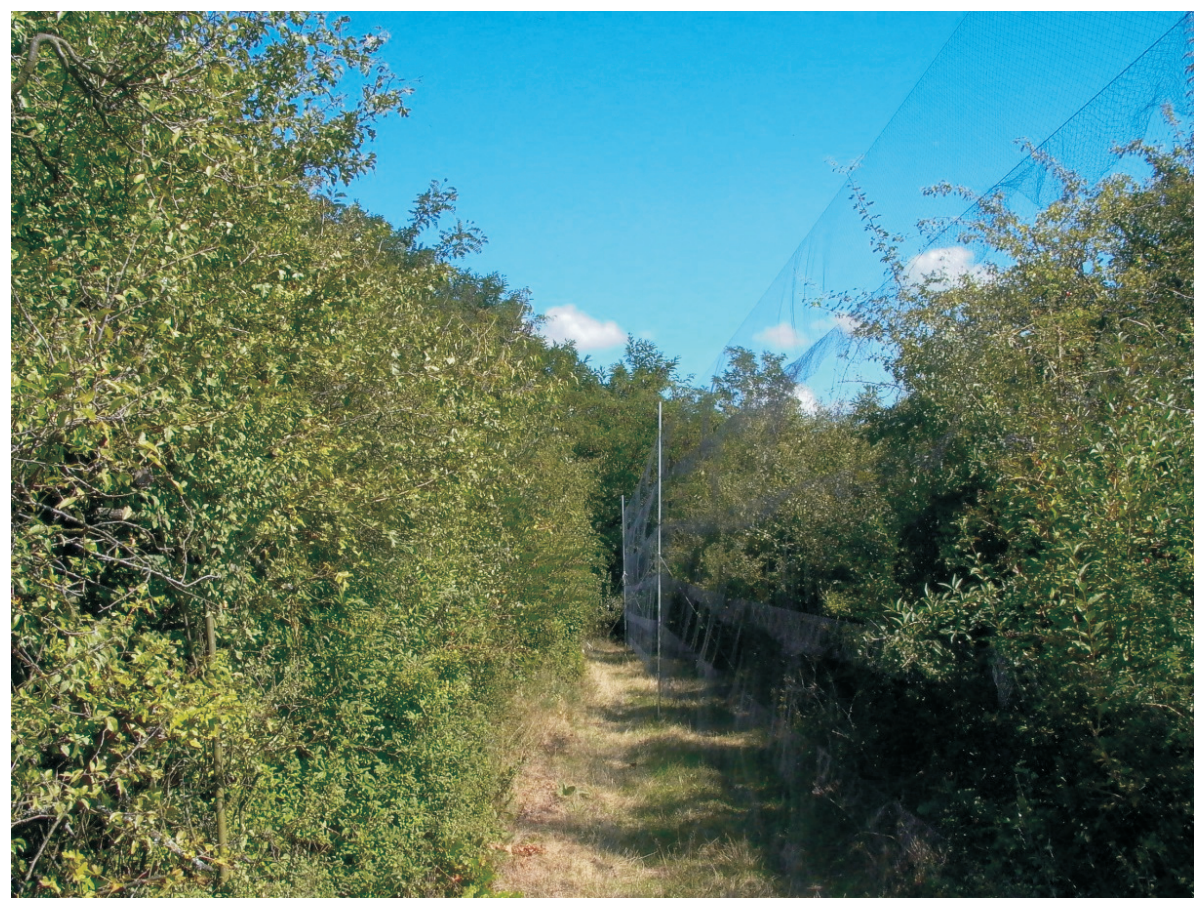

Photo 2. Mist-nets in the bushes 


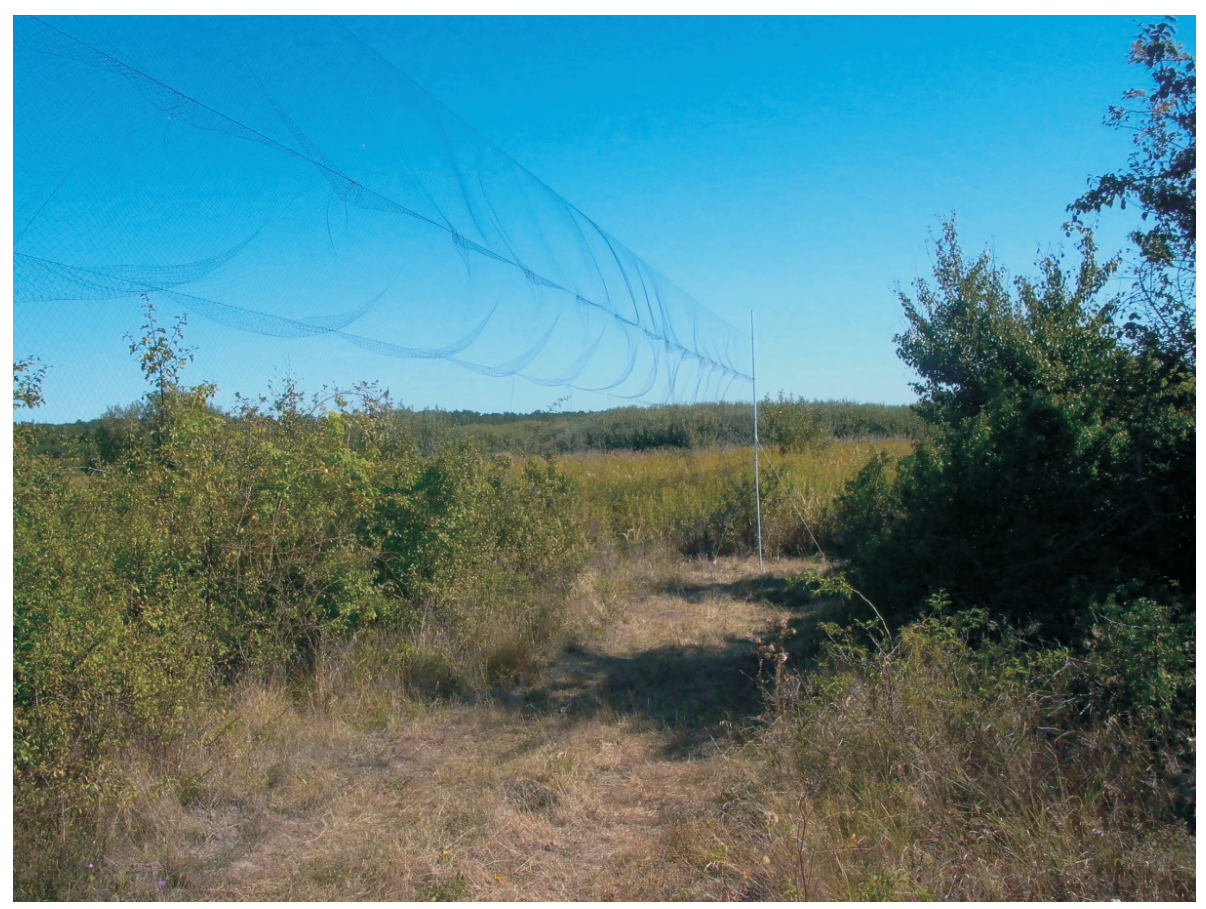

Photo 3. Mist-net in the grassland with scrubs

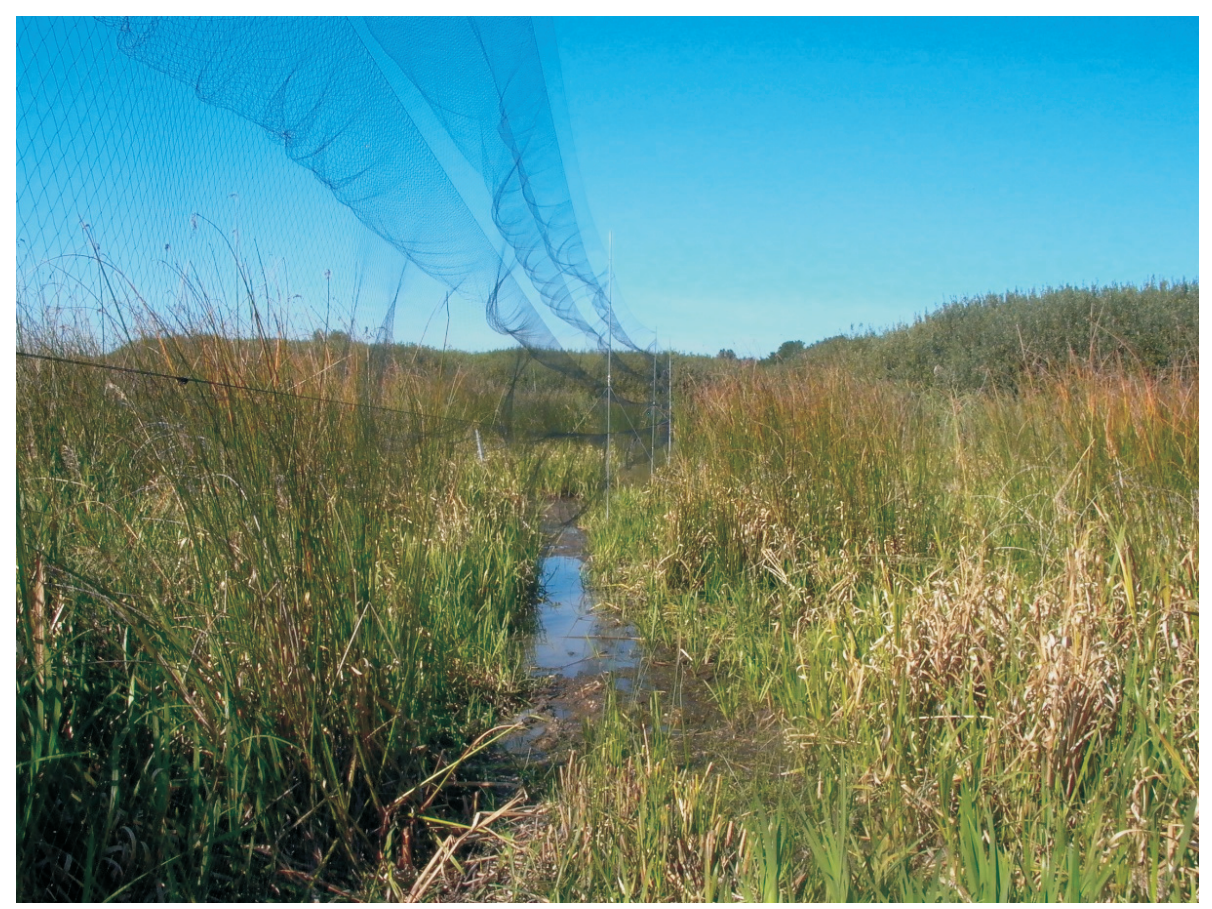

Photo 4. Mist-nets in the marsh 


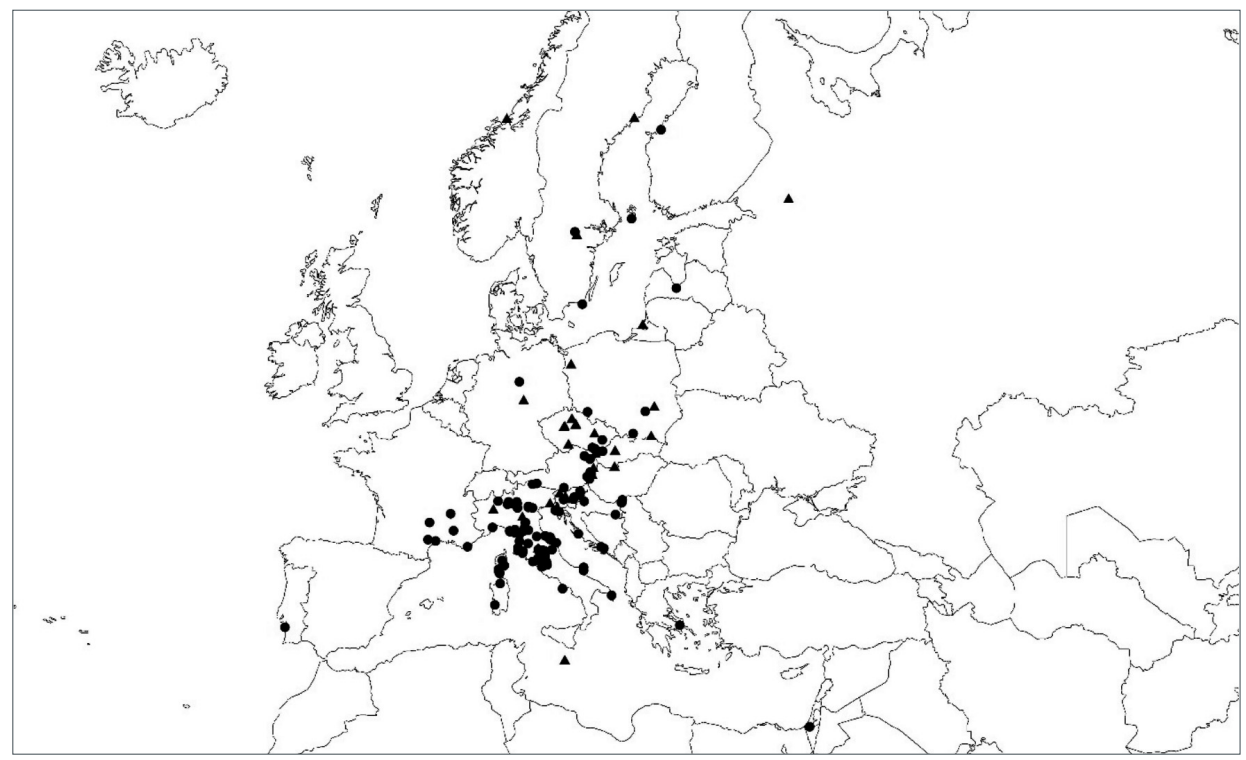

Fig. 4. Recoveries of birds ringed abroad and recovered in Tömörd (triangles) and bird ringed in Tömörd and recovered abroad (circles)

\section{RESULTS}

The species caught are listed below with short comments, and in most cases their status in the bird community is given (dominant, subdominant, accessory or rare). The numbers of individuals caught in each year are given in Appendix I, while Appendices $I I$ and $I I I$ contain species used in additional analyses. The species list follows systematics given in an annotated list of the birds of Hungary (Hadarics and Zalai 2008).

Eurasian Teal (Anas crecca). Appendix I.

In total, 2 juvenile Eurasian Teals were captured between 1998 and 2016. One juvenile bird was captured on 5 Sep. 2006 and another juvenile was captured on 27 Sep. 2011 in the marsh.

Garganey (Anas querquedula). Appendix I.

One juvenile bird of this species was captured on 10 Aug. 2004 in the marsh.

Grey Partridge (Perdix perdix). Appendix I.

One adult bird of this species was captured on 12 Oct. 2009 in the grassland.

Common Quail (Coturnix coturnix). Appendix I.

In total, 48 individuals of Common Quail were ringed between 1998 and 2016. The most birds were captured in 2003 (11 indiv.) and 2004 (10 indiv.). The date of the latest capture was 18 Oct. (2000). One individual was ringed on 4 Aug. 2016 in Tömörd and was recovered on 25 Aug. 2016 in Bosnia-Herzegovina. 
Common Pheasant (Phasianus colchicus). Appendix I.

In total, 11 individuals of Common Pheasant were ringed between 1998 and 2016. Two birds were captured in 2000 and 2002.

Eurasian Bittern (Botaurus stellaris). Appendix I.

One adult male of this species was captured on 20 Sep. 2013.

Little Bittern (Ixobrychus minutus). Appendix I.

In total, 8 individuals of Little Bittern were ringed between 1998 and 2016. The most birds ( 3 indiv.) were captured in 2013 and single individuals were captured in 2009, 2011, 2012, 2014 and 2016. All Little Bitterns were captured between 1 and 26 Aug.

Black-crowned Night Heron (Nyticorax nycticorax). Appendix I.

One juvenile bird was captured on 10 Aug. 2016.

Western Marsh Harrier (Circus aeruginosus). Appendix I.

In total, 6 individuals of Western Marsh Harrier were ringed between 1998 and 2016. One adult female of this species was captured on 20 Aug. 2000, 1 adult male and 1 juvenile female on 25 Aug. 2002, 1 adult female on 10 Aug. 2010, 1 adult male on 22 Aug. 2011, and 1 juvenile on 6 Aug. 2012.

Northern Goshawk (Accipiter gentilis). Appendix I.

In total, 4 individuals of Northern Hawk were ringed between 1998 and 2016. One bird of this species was captured on 15 Aug. 2001, 1 adult female was captured on 28 Jul. 2002, 1 juvenile bird was captured on 22 Sep. 2007 and 1 juvenile male was captured on 6 Oct. 2007.

Eurasian Sparrowhawk (Accipiter nisus). Appendix I.

In total, 23 individuals of Eurasian Sparrowhawk were ringed between 1998 and 2007. One bird was captured each year in 2001, 2002, 2004, 2006, 2015, and 2016, 2 birds each year in 2007, 2008, 2011, and 2014 and 3 birds each year in 2003, 2005 and 2012.

Common Buzzard (Buteo buteo). Appendix I.

The Common Buzzard was a very common species in the study area. In total, 22 Buzzard individuals were ringed between 1998 and 2016. The most birds were captured in 2012 (6 indiv.).

Common Kestrel (Falco tinnunculus). Appendix I.

In total, 2 Kestrel individuals were captured between 1998 and 2016. One bird was captured on 24 Aug. 2000 and 1 juvenile was captured on 5 Sep. 2012.

Peregrine Falcon (Falco peregrinus). Appendix $I$.

One juvenile female of this species was captured on 3 Nov. 2008.

Water Rail (Rallus aquaticus). Appendix I.

In total, 26 Water Rail individuals were ringed between 1998 and 2016. The most birds were captured in 2011 (6 indiv.). The date of the latest capture was 29 Oct. (2016).

Spotted Crake (Porzana porzana). Appendix I.

In total, 26 individuals of Spotted Crake were ringed between 1998 and 2016. The most birds (10 indiv.) were captured in 2004. The date of the last recapture was 9 Oct. (2013). 
Little Crake (Porzana parva). Appendix I.

One juvenile bird was captured on 3 Aug. 2013.

Corn Crake (Crex crex). Appendix I.

One juvenile male of this species was captured on 18 Sep. 2015.

Common Moorhen (Gallinula chloropus). Appendix I.

In total, 7 individuals of Common Moorhen were ringed between 1998 and 2016. The date of latest capture was 19 Sep. (2004).

Jack Snipe (Lymnocryptes minimus). Appendix I.

In total, 10 individuals of Jack Snipe were ringed between 1998 and 2016. The most birds (5 indiv.) were captured in 2013. The date of the latest capture was 25 Oct. (1999).

Common Snipe (Gallinago gallinago). Appendix I.

In total, 31 individuals of Common Snipe were ringed between 1998 and 2016. The most birds (10 indiv.) were captured in 2013. The date of the latest capture was 3 Nov. (2011). One individual ringed in Tömörd was recovered in France.

Eurasian Woodcock (Scolopax rusticola). Appendix I.

One juvenile bird of this species was captured in the bushes on 5 Nov. 2004.

Green Sandpiper (Tringa ochropus). Appendix I.

In total, 10 individuals of Green Sandpiper were ringed between 1998 and 2016. The most birds ( 2 indiv.) were captured in 2012. The date of the latest capture was 26 Aug. (2007).

Wood Sandpiper (Tringa glareola). Appendix I.

In total, 4 individuals of Wood Sandpiper were ringed between 1998 and 2016. The date of the latest capture was 15 Aug. (2007).

Eurasian Collared Dove (Strepotepelia decaocto). Appendix I.

One adult bird of this species was captured in the grassland on 31 Aug. 2009.

European Turtle Dove (Streptopelia turtur). Appendix I.

In total, 13 individuals of European Turtle Dove were ringed between 1998 and 2016. The most birds (4 indiv.) were captured in 1998. The date of the latest capture was 23 Sep. (2015).

Eurasian Scops Owl (Otus scops). Appendix I.

One juvenile bird of this species was captured in the bushes on 19 Aug. 2014.

Eurasian Pygmy Owl (Glaucidium passerinum). Appendix I.

One juvenile bird of this species was captured in the forest on 25 Aug. 2012.

Long-eared Owl (Asio otus). Appendix I.

In total, 19 individuals of Long-eared Owl were ringed between 1998 and 2016. The most birds (6 indiv.) were captured from August to early November in 2007. The date of the latest capture was 4 Nov. (2007).

Short-eared Owl (Asio flammeus). Appendix I.

One juvenile bird of this species was captured on 8 Sep. 2004.

European Nightjar (Caprimulgus europaeus). Appendix I.

In total, 5 individuals of European Nightjar were ringed between 1998 and 2016. The most birds ( 3 indiv.) were captured in 2015. The date of the latest capture was 28 Sep. (2013). 
Common Swift (Apus apus). Appendix I.

One bird of this species was captured in the marsh on 28 Aug. 1998.

Common Kingfisher (Alcedo atthis). Appendix I.

In total, 8 individuals of Common Kingfisher were ringed between 1998 and 2016. The date of the latest capture was 29 Oct. (2014). One individual ringed on 28 Jun. 2016 in Tömörd was recovered in Slovenia on 7 Jul. 2016.

\section{European Bee-eater (Merops apiaster). Appendix I.}

In total, 21 individuals of Bee-eater were ringed between 1998 and 2016. The most birds (15 indiv.) were captured in 2008. The date of the latest capture was 23 Aug. (1998).

Eurasian Hoopoe (Upopa epops). Appendix I.

One bird of this species was captured on 10 Sep. 2006 and another was captured in the grassland on 14 Aug. 2012.

Eurasian Wryneck (Jynx torquilla). Appendix I., Appendix II.A, Appendix III.A, Table 2, Fig. 5. The Wryneck was an accessory bird in the study area. In total, 266 Wryneck individuals were ringed between 1998 and 2016. The most birds (26 indiv.) were captured in 2013 and the fewest (7 indiv.) in 1999. The annual captures showed no significant trend from 2001 to 2016. Migration began in early August. The median date of the passage was 17 Aug. The date of the latest capture was 1 Oct. (2015).
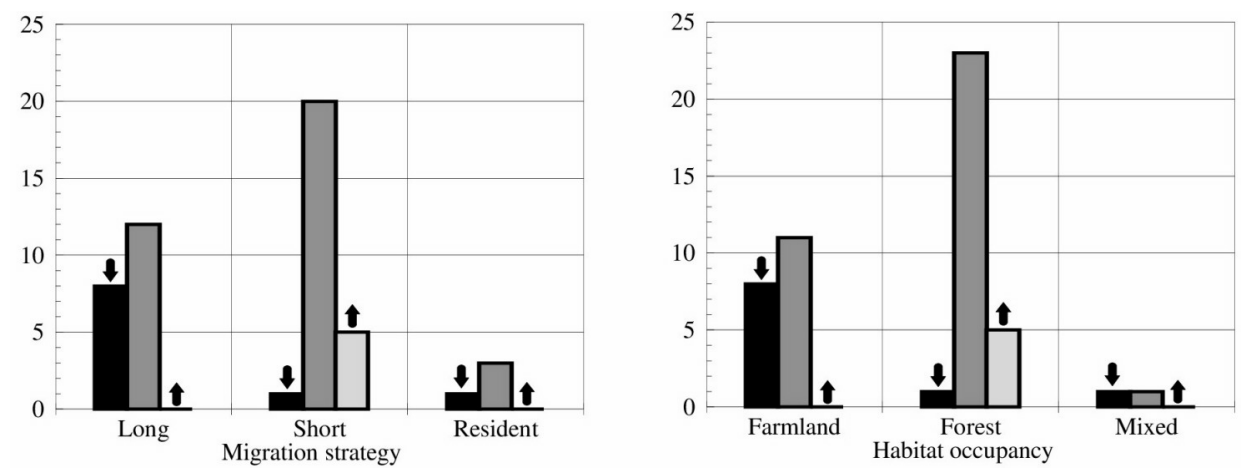

Fig. 5. Population trends of the species for which a significant decreasing, increasing or stable trend was estimated by linear regression analysis. Left panel - migration strategies, Right panel - habitat occupancy

Grey-headed Woodpecker (Picus canus). Appendix I.

The Grey-headed Woodpecker was a rare species in the study area. In total, 6 individuals of Grey-headed Woodpecker were ringed between 1998 and 2016. The date of the last recapture was 6 Nov. (2009).

European Green Woodpecker (Picus viridis). Appendix I.

The European Green Woodpecker was a rare species in the study area. In total, 55 individuals of Green Woodpecker were ringed between 1998 and 2016. The most birds (7 indiv., 6 in the bushes and 1 in the forest) were captured in 2007. The date of the latest capture was 7 Nov. (2015). One bird ringed on 3 Aug. 2003 was recovered dead on 10 Aug. 2011; this is the oldest known Green Woodpecker in Hungary. 
Table 2

The average population index in annual captures and the results of linear regression analysis used to estimate the long-term trends in the annual population indices over the study period. Habitat occupancy: $\mathrm{FA}=$ farmland, $\mathrm{F}=$ forest, $\mathrm{M}=$ mixed. Migration strategies: $\mathrm{L}=$ long-distance migrant, $\mathrm{S}=$ short-distance and partial migrant, $\mathrm{R}=$ resident.

\begin{tabular}{|c|c|c|c|c|c|c|c|}
\hline Species & $\begin{array}{l}\text { Avg. } \\
\text { Index }\end{array}$ & Slope & $S E$ & $r$ & $p$ & Habitat & $\begin{array}{c}\text { Migra- } \\
\text { tion }\end{array}$ \\
\hline Jynx torquilla & 175.625 & 3.11 & 3.26 & 0.25 & 0.36 & FA & $\mathrm{L}$ \\
\hline Dendrocopos major & 203.125 & 1.54 & 5.16 & 0.08 & 0.77 & $\mathrm{~F}$ & $\mathrm{R}$ \\
\hline Hirundo rustica & 120.25 & -16.27 & 4.93 & -0.66 & 0.01 & FA & $\mathrm{L}$ \\
\hline Delichon urbicum & 542.38 & -103.04 & 37.68 & -0.59 & 0.02 & FA & $\mathrm{L}$ \\
\hline Anthus trivialis & 165.56 & -22.43 & 9.62 & -0.53 & 0.04 & $\mathrm{~F}$ & $\mathrm{~L}$ \\
\hline Troglodytes troglodytes & 96.38 & 4.31 & 2.06 & 0.49 & 0.06 & $\mathrm{~F}$ & $\mathrm{~S}$ \\
\hline Prunella modularis & 190.06 & 4.83 & 3.35 & 0.36 & 0.17 & $\mathrm{~F}$ & $\mathrm{~S}$ \\
\hline Erithacus rubecula & 107.69 & 3.14 & 1.09 & 0.61 & 0.01 & $\mathrm{~F}$ & $\mathrm{~S}$ \\
\hline Phoenicurus ochruros & 61.69 & -3.24 & 1.11 & -0.62 & 0.01 & M & S \\
\hline Phoenicurus phoenicurus & 81.88 & 0.00 & 2.36 & 0.00 & 1.00 & FA & $\mathrm{L}$ \\
\hline Saxicola rubetra & 91.94 & -15.44 & 5.53 & -0.60 & 0.01 & FA & $\mathrm{L}$ \\
\hline Saxicola torquatus & 49.19 & -7.05 & 1.21 & -0.84 & 0.00 & FA & $\mathrm{L}$ \\
\hline Turdus merula & 211.63 & 19.10 & 4.03 & 0.79 & 0.00 & $\mathrm{~F}$ & $\mathrm{~S}$ \\
\hline Turdus philomelos & 210.44 & 11.54 & 4.00 & 0.61 & 0.01 & $\mathrm{~F}$ & $\mathrm{~S}$ \\
\hline Turdus iliacus & 32.06 & -1.31 & 1.65 & -0.21 & 0.44 & FA & $\mathrm{S}$ \\
\hline Locustella naevia & 56.81 & -4.22 & 1.74 & -0.54 & 0.03 & FA & $\mathrm{L}$ \\
\hline Acrocephalus schoenobaenus & 3431.25 & 136.32 & 158.20 & 0.22 & 0.40 & FA & $\mathrm{L}$ \\
\hline Acrocephalus scirpaceus & 600.00 & 15.74 & 23.42 & 0.18 & 0.51 & FA & $\mathrm{L}$ \\
\hline Acrocephalus palustris & 611.25 & -12.44 & 24.00 & -0.14 & 0.61 & FA & $\mathrm{L}$ \\
\hline Hippolais icterina & 308.88 & 0.20 & 9.32 & 0.01 & 0.98 & $\mathrm{~F}$ & $\mathrm{~L}$ \\
\hline Sylvia atricapilla & 256.25 & 19.13 & 4.08 & 0.78 & 0.00 & $\mathrm{~F}$ & $\mathrm{~S}$ \\
\hline Sylvia borin & 299.06 & 5.20 & 5.35 & 0.25 & 0.35 & FA & $\mathrm{L}$ \\
\hline Sylvia curruca & 166.56 & -1.43 & 2.13 & -0.18 & 0.51 & FA & $\mathrm{L}$ \\
\hline Sylvia communis & 135.63 & -5.94 & 2.29 & -0.57 & 0.02 & FA & $\mathrm{L}$ \\
\hline Phylloscopus sibilatrix & 268.13 & 9.67 & 10.80 & 0.23 & 0.39 & $\mathrm{~F}$ & $\mathrm{~L}$ \\
\hline Phylloscopus collybita & 127.56 & 3.12 & 1.22 & 0.57 & 0.02 & $\mathrm{~F}$ & $\mathrm{~S}$ \\
\hline Phylloscopus trochilus & 61.00 & -3.98 & 2.13 & -0.45 & 0.08 & $\mathrm{~F}$ & $\mathrm{~L}$ \\
\hline Regulus regulus & 42.25 & -0.36 & 1.71 & -0.06 & 0.84 & $\mathrm{~F}$ & $S$ \\
\hline Regulus ignicapillus & 78.44 & 1.77 & 1.22 & 0.36 & 0.17 & $\mathrm{~F}$ & $\mathrm{~S}$ \\
\hline Muscicapa striata & 77.25 & 0.94 & 1.68 & 0.15 & 0.59 & $\mathrm{~F}$ & $\mathrm{~L}$ \\
\hline Ficedula hypoleuca & 65.06 & -1.10 & 1.52 & -0.19 & 0.48 & $\mathrm{~F}$ & $\mathrm{~L}$ \\
\hline Aegithalos caudatus & 70.88 & -0.42 & 1.47 & -0.08 & 0.78 & $\mathrm{~F}$ & $\mathrm{~S}$ \\
\hline Parus palustris & 123.63 & -2.74 & 2.91 & -0.24 & 0.36 & $\mathrm{~F}$ & $\mathrm{~S}$ \\
\hline Parus ater & 2593.75 & 184.12 & 308.01 & 0.16 & 0.56 & $\mathrm{~F}$ & $\mathrm{~S}$ \\
\hline Parus caeruleus & 213.00 & -3.61 & 8.57 & -0.11 & 0.68 & $\mathrm{~F}$ & $\mathrm{~S}$ \\
\hline Parus major & 209.81 & -2.97 & 8.19 & -0.10 & 0.72 & $\mathrm{~F}$ & $\mathrm{~S}$ \\
\hline Sitta europaea & 61.63 & -1.95 & 1.97 & -0.26 & 0.34 & $\mathrm{~F}$ & $\mathrm{R}$ \\
\hline Cerhtia familiaris & 100.50 & 1.57 & 3.72 & 0.11 & 0.68 & $\mathrm{~F}$ & $\mathrm{R}$ \\
\hline
\end{tabular}




\begin{tabular}{|l|r|r|r|r|r|c|c|}
\hline \multicolumn{1}{|c|}{ Species } & $\begin{array}{c}\text { Avg. } \\
\text { Index }\end{array}$ & Slope & \multicolumn{1}{c|}{$S E$} & $r$ & $p$ & Habitat & $\begin{array}{c}\text { Migra- } \\
\text { tion }\end{array}$ \\
\hline Lanius collurio & 85.94 & $\mathbf{- 5 . 1 0}$ & $\mathbf{1 . 1 2}$ & $\mathbf{- 0 . 7 7}$ & $\mathbf{0 . 0 0}$ & FA & $\mathrm{L}$ \\
\hline Garrulus glandarius & 276.25 & -2.38 & 13.61 & -0.05 & 0.86 & $\mathrm{~F}$ & $\mathrm{~S}$ \\
\hline Sturnus vulgaris & 3634.38 & 590.81 & 277.63 & 0.49 & 0.05 & $\mathrm{~F}$ & $\mathrm{~S}$ \\
\hline Passer montanus & 111.81 & $\mathbf{- 1 3 . 5 3}$ & $\mathbf{4 . 4 2}$ & $\mathbf{- 0 . 6 3}$ & $\mathbf{0 . 0 1}$ & $\mathrm{FA}$ & $\mathrm{R}$ \\
\hline Fringilla coelebs & 465.00 & -18.12 & 42.16 & -0.11 & 0.67 & $\mathrm{~F}$ & $\mathrm{~S}$ \\
\hline Fringilla montifringilla & 3925.00 & -256.47 & 565.21 & -0.12 & 0.66 & $\mathrm{~F}$ & $\mathrm{~S}$ \\
\hline Carduelis chloris & 367.00 & 13.87 & 17.83 & 0.20 & 0.45 & $\mathrm{FA}$ & $\mathrm{S}$ \\
\hline Carduelis carduelis & 87.19 & 0.71 & 7.53 & 0.03 & 0.93 & $\mathrm{FA}$ & $\mathrm{S}$ \\
\hline Pyrrhula pyrrhula & 95.88 & -1.42 & 4.04 & -0.09 & 0.73 & $\mathrm{~F}$ & $\mathrm{~S}$ \\
\hline Coccothraustes coccothraustes & 401.56 & -0.43 & 28.55 & 0.00 & 0.99 & $\mathrm{~F}$ & $\mathrm{~S}$ \\
\hline Emberiza citrinella & 92.88 & -0.97 & 2.32 & -0.11 & 0.68 & $\mathrm{M}$ & $\mathrm{S}$ \\
\hline Emberiza schoeniclus & 195.06 & 2.19 & 6.81 & 0.09 & 0.75 & FA & $\mathrm{S}$ \\
\hline
\end{tabular}

Black Woodpecker (Dryocopus martius). Appendix I.

The Black Woodpecker was a rare species in the study area. In total, 18 individuals of Black Woodpecker were ringed between 1998 and 2016. The date of the last recapture was 6 Nov. (2015).

Great Spotted Woodpecker (Dendrocopos major). Appendix I., Appendix II.A, Appendix III.A, Table 2, Fig. 5.

The Great Spotted Woodpecker was a rare species in the study area. In total, 209 individuals of Great Spotted Woodpecker were ringed between 1998 and 2016. The most birds (27 indiv.) were captured from July to November in 2008. The annual captures showed no significant trend from 2000 to 2016.

Syrian Woodpecker (Dendrocopos syriacus). Appendix I.

The Syrian Woodpecker was a very rare species in the study area. One bird was captured each year in 2001 and in 2006.

Middle Spotted Woodpecker (Dendrocopos medius). Appendix I.

The Middle Spotted Woodpecker was a very rare species in the study area. In total, 34 individuals of Middle Spotted Woodpecker were ringed between 1998 and 2016.

Lesser Spotted Woodpecker (Dendrocopos minor). Appendix I.

The Lesser Spotted Woodpecker was a rare species in the study area. In total, 93 individuals of Lesser Spotted Woodpecker were ringed between 1998 and 2016. The most birds (12 indiv.) were captured from early August to the end of October in 2004.

Eurasian Skylark (Alauda arvensis). Appendix I.

The Eurasian Skylark was a rare species in the study area. In total, 93 individuals of Eurasian Skylark were ringed between 1998 and 2016. The date of the last recapture was 25 Aug. (2001).

Sand Martin (Riparia riparia). Appendix I.

The Sand Martin was a rare songbird species in the study area. In total, 16 individuals of Sand Martin were ringed between 1998 and 2016. The most birds (6 indiv.) were captured in 2004. 
Barn Swallow (Hirundo rustica). Appendix I., Appendix II.A, Appendix III.A, Table 2, Fig. 5.

In total, 1,587 individuals of Barn Swallow were ringed between 1998 and 2016. The most birds were captured in 2002 and the fewest in 2013. The annual captures showed a significant strong decreasing trend from 2001 to 2016. The species migrated in a relatively numerous wave with three peaks until early October. The median date of the passage was 9 Aug. The date of the latest capture was 7 Oct (2010). One adult female was recovered in Italy.

Common House Martin (Delichon urbicum). Appendix I., Appendix II.A, Appendix III.A, Table 2, Fig. 5.

In total, 743 individuals of Common House Martin were ringed between 1998 and 2016. The most birds were captured in 2003, and there were no captures in the last five years. The annual captures showed a significant steep decreasing trend between 2001 and 2016. The species migrated in a relatively numerous wave with four peaks until the end of September. The median date of the passage was 14 Aug. The date of the latest capture was 26 Sep. (2003).

Tree Pipit (Anthus trivialis). Appendix I., Appendix II.A, Appendix III.A, Table 2, Fig. 5. In total, 932 individuals of Tree Pipit were ringed between 1998 and 2016. The most birds ( 251 indiv.) were captured in 2002 and the fewest (9 indiv.) in 2013. The annual captures showed a significant strong decreasing trend from 2001 to 2016 . The migration pattern showed one migration wave with a definite peak in early September, and then the number of captured birds decreased until mid-October. The median date of the passage was 4 Sep. The date of the latest capture was 14 Oct. (2016). One juvenile bird was recovered in Finland.

\section{Meadow Pipit (Anthus pratensis). Appendix I.}

The Meadow Pipit was a rare songbird species in the study area. In total, 81 individuals of Meadow Pipit were ringed between 1998 and 2016. The most birds (14 indiv.) were captured in 2010. There was no capture in 2011. Before 20 Aug., Meadow Pipits were caught only in 2006. The migration began in early September. The median date of the passage was 16 Oct. The date of the latest capture was 11 Nov. The peak migration period was at the end of October and early November in the years 2001-2016.

\section{Red-throated Pipit (Anthus cervinus). Appendix I.}

One juvenile bird of this species was captured in the marsh on 9 Oct. 2009.

Water Pipit (Anthus spinolenta). Appendix I.

One adult bird of this species was captured in the marsh on 1 Oct. 2003.

\section{Western Yellow Wagtail (Motacilla flava). Appendix I.}

The Yellow Wagtail was a rare songbird species in the study area. In total, 23 individuals of Yellow Wagtail were ringed between 1998 and 2016. The most birds (7 indiv.) were captured at the end of August and in September 2003.

Grey Wagtail (Motacilla cinerea). Appendix I.

The Grey Wagtail was a rare songbird species in the study area. In total, 30 individuals of Grey Wagtail were ringed between 1998 and 2016. The most birds (14 indiv.) were captured in the second half of August and early September 1998. 
White Wagtail (Motacilla alba). Appendix I.

The White Wagtail was a rare songbird species in the study area. In total, 75 individuals of White Wagtail were ringed between 1998 and 2016. The most birds (20 indiv.) were captured in 2003.

Winter Wren (Troglodytes troglodytes). Appendix I., Appendix II.A, Appendix III.A, Table 2, Fig. 5.

The Wren was a rare songbird species in the post-breeding dispersal period, but was a subdominant passerine in the study area during autumn migration. In total, 1,082 individuals of Winter Wren were ringed between 1998 and 2016. The most birds (105 indiv.) were captured in 2015 and the fewest (12 indiv.) in 2012. The annual captures showed no significant trend in the years 2001-2016. Migration of the Wren began in mid-September. The median date of the passage was 20 Oct. The peak migration period was at the end of October in the years 2001-2016. The date of the latest capture was 10 Nov. (2006).

Dunnock (Prunella modularis). Appendix I., Appendix II.B, Appendix III.B, Table 2, Fig. 5. The Dunnock was a rare songbird species in the post-breeding dispersal period, but was a subdominant passerine in the study area during autumn migration. In total, 1910 Dunnock individuals were ringed between 1998 and 2016. The most birds (182 indiv.) were captured in 2008 and the fewest (10 indiv.) in 1998. The annual captures showed no significant trend in the years 2001-2016. The migration of the Dunnock started at the end of September. The median date of the passage was 9 Oct. The peak migration period was in early October in the years 2001-2016. The date of the latest capture was 8 November (2003).

Red-flanked Bluetail (Tarsiger cyanurus). Appendix I., Photo 5.

One juvenile bird of this species was captured on 12 Oct. 2010 in the bushes. This was the first record and ringed specimen of the Red-flanked Bluetail in Hungary.

European Robin (Erithacus rubecula). Appendix I., Appendix II.B, Appendix III.B, Table 2, Fig. 5.

The European Robin was a superdominant songbird species in the study area. In total, 14,377 individuals of European Robin were ringed between 1998 and 2016. During autumn migration the most birds (1,195 indiv.) were captured in 2016 and the fewest (229 indiv.) in 1998. The annual captures showed a significant moderate increasing trend during the years 2001-2016. The migration of the European Robin began at the end of August. The median date of the passage was 2 Oct. In 2001-2016 the migration pattern showed one strong migration wave with two distinct peaks at the end of September and mid-October, and then the number of captured birds decreased until early November. The date of the latest capture was 18 Nov. (2000). Nine individuals ringed in Tömörd were recovered abroad: 4 in Italy, 3 in Austria and 1 each in the Czech Republic and Slovakia. Two birds ringed in Italy and one bird ringed in Poland were recovered in Tömörd.

Thrush Nightingale (Luscinia luscinia). Appendix I.

The Thrush Nightingale was a rare songbird species in the study area. In total, 57 individuals of Thrush Nightingale were ringed between 1998 and 2016. All birds were captured in August. One bird ringed in Tömörd was recovered in Sweden. 


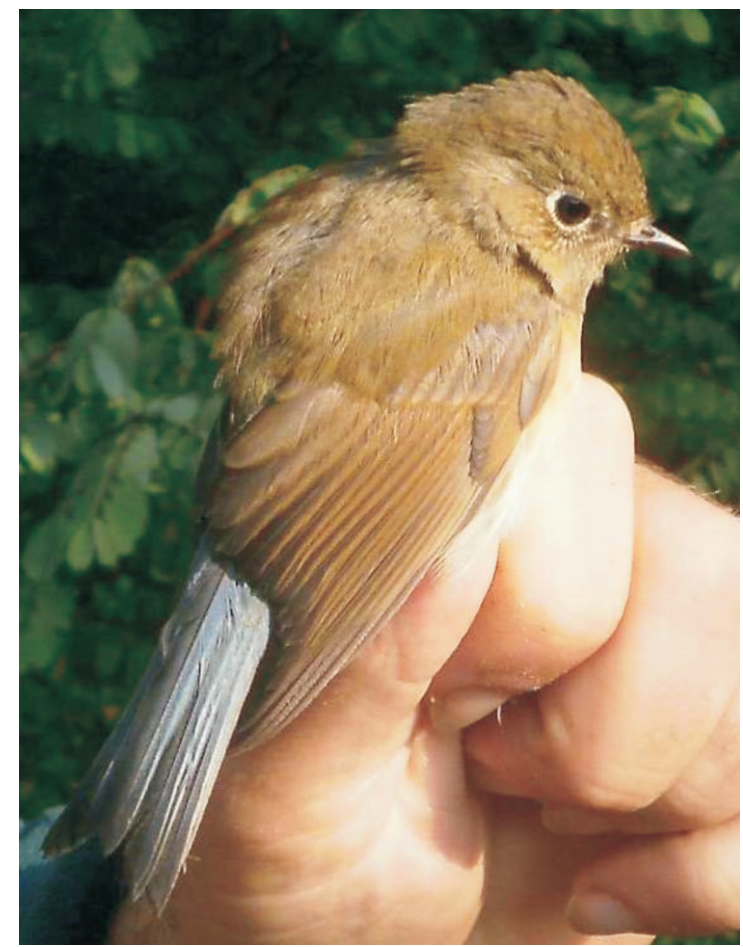

Photo 5. First record of the Red-flanked Bluetail in Hungary

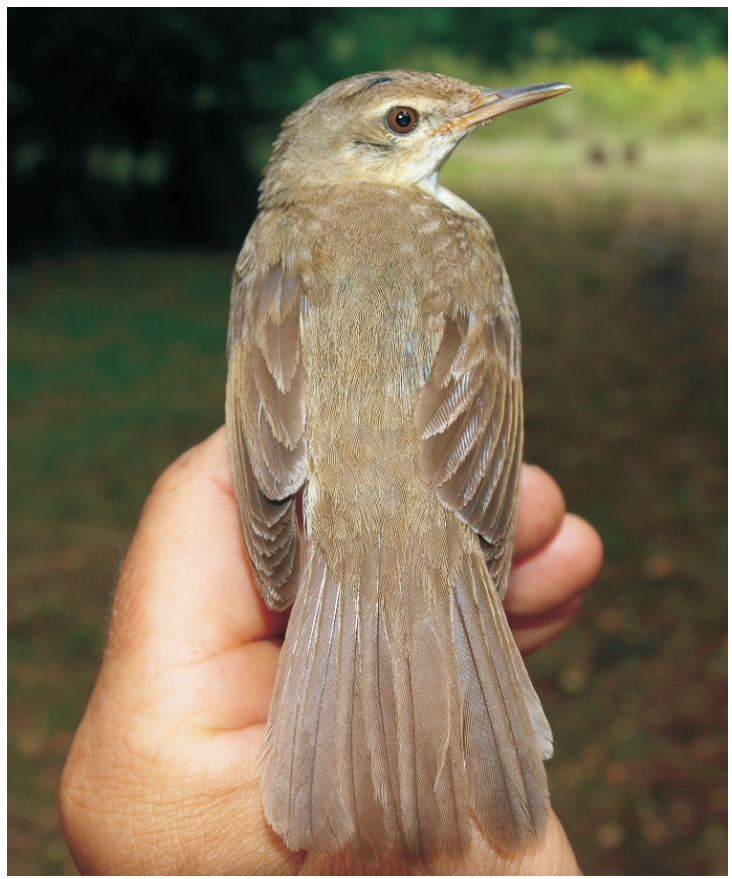

Photo 6. First record of the Blyth's Reed Warbler in Hungary 
Common Nightingale (Luscinia megarhynchos). Appendix I.

The Nightingale was a rare songbird species in the study area. In total, 180 Nightingale individuals were ringed between 1998 and 2016. The most birds (20 indiv.) were captured in 2008 and the fewest (1 indiv.) in 2000. The most birds were captured in August. The date of the latest capture was 21 Sep. (2001).

Bluethroat (Luscinia luscinia). Appendix $I$.

The Bluethroat was a very rare songbird species in the study area. In total, 9 Bluethroat individuals were ringed between 1998 and 2016. The date of the first capture was 21 Aug. (2016) and the date of the latest capture was 3 Oct. (2000).

Black Redstart (Phoenicurus ochruros). Appendix I., Appendix II.B, Appendix III.B, Table 2, Fig. 5.

The Black Redstart was an accessory songbird in the study area. In total, 476 individuals of Black Redstart were ringed between 1998 and 2016. The most birds (43 indiv.) were captured in 2001 and the fewest (5 indiv.) in 1998. The annual captures showed a significant moderate decreasing trend during the years 2001-2016. The migration of the Black Redstart started in the mid-September. The median date of the passage was 7 Oct. The migration pattern showed two migration waves with two distinct peaks in early October and at the end of October in 2001-2016.The date of the latest capture was 10 Nov. (2000).

Common Redstart (Phoenicurus phoenicurus). Appendix I., Appendix II.B, Appendix III.B, Table 2, Fig. 5.

The Common Redstart was an accessory songbird in the study area. In total, 341 Common Redstart individuals were ringed between 1998 and 2016. The most birds (52 indiv.) were captured in 2012 and the fewest (4 indiv.) in 1998. The annual captures showed no significant trend during the years 2001-2016. The migration of the Common Redstart began in mid-August. The median date of the passage was 18 Sep. In 2001-2016, the migration pattern showed one migration wave with one distinct peak at the end of September. The date of the latest capture was 22 Oct. (2009).

Whinchat (Saxicola rubetra). Appendix I., Appendix II.B, Appendix III.B, Table 2, Fig. 5. The Whinchat was an accessory songbird in the study area. In total, 246 Whinchat individuals were ringed between 1998 and 2016. The most birds (74 indiv.) were captured in 2002, and there was no capture in 1999 or 2016. The annual captures showed a significant strong decreasing trend in the years 2001-2016. The migration of the Whinchat began in early August. The median date of the passage was 29 Aug. The migration pattern showed one migration wave with one peak at the end of August in the years 2001-2016.The date of the latest capture was 6 Oct. (2004).

Eurasian Stonechat (Saxicola torquatus). Appendix I., Appendix II.B, Appendix III.B, Table 2, Fig. 5.

The Eurasian Stonechat was an accessory songbird in the study area. In total, 391 individuals of Eurasian Stonechat were ringed between 1998 and 2016. The most birds (61 indiv.) were captured in 2002 and there were no captures in 1998. The annual captures showed a significant strong decreasing trend during the years 2001-2016. The migration of the Stonechat started in mid-August. The median date of the passage was 22 Sep. The species showed two smaller migration waves in August and another 
relatively high wave at the end of September and in early October in the years 2001-2016. The date of the latest capture was 30 Oct. (2011).

Northern Wheatear (Oenanthe oenanthe). Appendix I.

The Northern Wheatear was a very rare songbird species in the study area. In total, 16 Wheatear individuals were ringed between 1998 and 2016. The most birds (4 indiv.) were captured in 2002. The date of the latest capture was 1 Oct. (2002).

Common Blackbird (Turdus merula). Appendix I., Appendix II.B, Appendix III.B, Table 2, Fig. 5.

The Common Blackbird was a dominant songbird species in the study area. In total, 5,968 Blackbirds were ringed between 1998 and 2016. The most birds (697 indiv.) were captured in 2016 and the fewest (119 indiv.) in 2002. The annual captures showed a significant strong increasing trend during the years 2001-2016. The Common Blackbird began migration in early September. The median date of the passage was 12 Oct. The peak migration period was in mid-October (8-17) in the years 2001-2016. The date of the latest capture was 18 Nov. (2001). Twenty-six Common Blackbirds ringed in Tömörd were recovered abroad: 20 indiv. in Italy, 4 in France and 1 each in Austria and Poland. One bird ringed in Italy was recovered in Tömörd.

Fieldfare (Turdus pilaris). Appendix I.

The Fieldfare was a rare songbird species in the study area. In total, 61 Fieldfare individuals were ringed between 1998 and 2016. The most birds (19 indiv.) were captured from 24 Oct. in 2015. There were no captures in 1998, 2001, 2003, 2006 or 2013.

Song Thrush (Turdus philomelos). Appendix I., Appendix II.B, Appendix III.B, Table 2, Fig. 5.

The Song Thrush was a dominant songbird species in the study area. In total, 2,315 individuals of Song Thrush were ringed between 1998 and 2016. The most birds (245 indiv.) were captured in 2011 and the fewest (21 indiv.) in 1998. The annual captures showed a significant strong increasing trend in the years 2001-2016. The Song Thrush began migration in early September. The median date of the passage was 5 Oct. The peak migration period was in the first half of October (1 to 15) in the years 2001-2016. The date of the latest capture was 9 Nov. (2001). Eleven birds ringed in Tömörd were recovered abroad: 8 in Italy and 3 in France. One Song Thrush ringed in Poland was recovered in Tömörd.

Redwing (Turdus iliacus). Appendix I., Appendix II.C, Appendix III.C, Table 2, Fig. 5. The Redwing was an accessory songbird in the study area. In total, 593 Redwing individuals were ringed between 1998 and 2016. The most birds (108 indiv.) were captured in 2001, and there were no captures in 1988. The annual captures showed no significant trend during the years 2001-2016. The Redwing migration began in midOctober. The date of the earliest capture was 14 Oct. The median date of the passage was 30 Oct. The peak migration period was in early November in the years 2001-2016. Four birds ringed in Tömörd were recovered abroad: 1 indiv. each in France and Greece and 2 in Italy.

Mistle Thrush (Turdus viscivorus). Appendix I.

The Mistle Thrush was a very rare bird species in the study area. In total, 7 individuals of Mistle Thrush were ringed between 1998 and 2016. 
Common Grasshopper Warbler (Locustella naevia). Appendix I., Appendix II.C, Appendix III.C, Table 2, Fig. 5.

The Common Grasshopper Warbler was an accessory songbird in the study area. In total, 221 individuals of Common Grasshopper Warbler were ringed between 1998 and 2016. The most birds ( 29 indiv.) were captured in 2003 and the fewest (2 indiv.) in 2013. The annual captures showed a significant moderate decreasing trend during the years 2001-2016. The Common Grasshopper Warbler migration began at the end of July, followed by some smaller waves until early October. The median date of the passage was 21 Aug. The date of the latest capture was 5 Oct. (2010).

River Warbler (Locustella fluviatilis). Appendix I.

The River Warbler was a rare songbird species in the study area. In total, 53 individuals of River Warbler were ringed between 1998 and 2016. The most birds (9 indiv.) were captured in August and the first half of September 2004. The date of the latest capture was 13 Sep. (2004).

Savi's Warbler (Locustella luscinioides). Appendix I.

The Savi's Warbler was a rare songbird species in the study area. In total, 47 individuals of Savi's Warbler were ringed between 1998 and 2016. The first capture was in 2003. There were no captures from 1998 to 2002. The most birds (23 indiv.) were captured from 2 Aug. to 15 Sep. in 2015. The date of the latest capture was 16 Sep. (2012). One bird ringed in the Czech Republic was recovered in Tömörd.

Moustached Warbler (Acrocephalus melanopogon). Appendix I.

The Moustached Warbler was a very rare songbird species in the study area. In total, 3 individuals (1 indiv. each in 2004, 2013 and 2016) of Moustached Warbler were ringed between 1998 and 2016.

Sedge Warbler (Acrocephalus schoenobaenus). Appendix I., Appendix II.C, Appendix III.C, Table 2, Fig. 5.

The Sedge Warbler was an accessory songbird in the study area. In total, 596 individuals of Sedge Warbler were ringed between 1998 and 2016. The most birds were captured in 2004 (109 indiv.) and the fewest in 2001 (1 indiv.), when the lake was dried out. The annual captures showed no significant trend in the years 2001-2016. The Sedge Warbler migration began at the end of July, followed by some smaller waves to the end of September. The median date of the passage was 27 Aug. The date of the latest capture was 1 Nov. (2009). One juvenile bird ringed in Tömörd was recovered in Sweden and one juvenile bird ringed in Slovenia was recovered in Tömörd.

Blyth's Reed Warbler (Acrocephalus dumetorum). Appendix I., Photo 6.

One adult bird of this species was captured in the grassland on 15 Aug. 2014. This was the first record of the Blyth's Reed Warbler in Hungary.

Eurasian Reed Warbler (Acrocephalus scirpaceus). Appendix I., Appendix II.C, Appendix III.C, Table 2, Fig. 5.

The Eurasian Reed Warbler was an accessory songbird in the study area. In total, 203 individuals of Eurasian Reed Warbler were ringed between 1998 and 2016. The most birds were captured in 2016 ( 31 indiv.) and the fewest in 2000 (2 indiv.) and 2001 ( 2 indiv.), when the lake was dried out. The annual captures showed no significant trend during the years 2001-2016. The Eurasian Reed Warbler migration started at 
the end of July, followed by some smaller waves to the end of September. The median date of the passage was 24 Aug. The date of the latest capture was 7 Oct. (2004).

Marsh Warbler (Acrocephalus palustris). Appendix I., Appendix II.C, Appendix III.C, Table 2, Fig. 5.

The Marsh Warbler was an accessory songbird in the study area. In total, 510 individuals of Marsh Warbler were ringed between 1998 and 2016. The most birds were captured in 2004 ( 89 indiv.) and the fewest in 2000 (5 indiv.) and 2001 (5 indiv.), when the lake was dried out. The annual captures showed no significant trend during the years 2001-2016. The Marsh Warbler migration began at the end of July, followed by some smaller waves to the end of September. The median date of the passage was 16 Aug. The date of the latest capture was 30 Sep. (2004).

Great Reed Warbler (Acrocephalus arundinaceus). Appendix I.

The Great Reed Warbler was a very rare songbird species in the study area. In total, 17 individuals of Great Reed Warbler were ringed between 1998 and 2016. The first capture was in 2003. The most birds (4 indiv.) were captured in early August 2004. The date of the latest capture was 18 Sep (2016).

Icterine Warbler (Hippolais icterina). Appendix I., Appendix II.C, Appendix III.C, Table 2, Fig. 5.

The Icterine Warbler was an accessory songbird in the study area. In total, 374 individuals of Icterine Warbler were ringed between 1998 and 2016. The most birds (47 indiv.) were captured in 2012 and the fewest (4 indiv.) in 2000, when the lake was dried out. The annual captures showed no significant trend in the years 2001-2016. Migration of this species began at the end of July, with a relatively strong wave lasting for two weeks (5 to 20 Aug.), followed by some smaller waves from 21 Aug. to 5 Sep. The median date of the passage was 19 Aug. The species may have finished migration at the end of September. The date of the latest capture was 28 Sep (1999 and 2010).

Eurasian Blackcap (Sylvia atricapilla). Appendix I., Appendix II.C, Appendix III.C, Table 2, Fig. 5.

The Eurasian Blackcap was a superdominant songbird species in the study area. In total, 13,926 individuals of Eurasian Blackcap were ringed between 1998 and 2016. The most birds (1,671 indiv.) were captured in 2016 and the fewest (236 indiv.) in 2000. The annual captures showed a significant strong increasing trend in 2001-2016. Migration of this species began in early August, followed by one long wave with a high peak from 2 to $21 \mathrm{Sep}$. The median date of the passage was $10 \mathrm{Sep}$. The species may have finished migration at the end of October. The date of the latest capture was 7 Nov. (2007). Four individuals ringed in Tömörd were recovered abroad: one each in Austria, Croatia, the Czech Republic and Slovenia. Two birds ringed in the Czech Republic and Slovenia and one each ringed in Poland and Sweden were recovered in Tömörd.

Garden Warbler (Sylvia borin). Appendix I., Appendix II.C, Appendix III.C, Table 2, Fig. 5.

The Garden Warbler was an accessory songbird in the study area. In total, 1,024 individuals of Garden Warbler were ringed between 1998 and 2016. The most birds ( 88 indiv.) were captured in 2008 and the fewest (16 indiv.) in 2000. The annual cap- 
tures showed no significant trend in 2001-2016. The Garden Warbler migration began in early August with a relatively strong wave lasting until mid-August, followed by one smaller wave from mid-August to mid-September. The median date of the passage was 26 Aug. The species finished its passage in early October. The date of the latest capture was 4 Oct. (2012). One bird ringed in Tömörd was recovered in Italy.

Barred Warbler (Sylvia nisoria). Appendix I.

The Barred Warbler was a rare songbird species in the study area. In total, 92 individuals of Barred Warbler were ringed between 1998 and 2016. The most birds (16 indiv.) were captured in 2013. There were no captures in 1999, 2000 or 2001. The date of the latest capture was 27 Sep (2007).

Lesser Whitethroat (Sylvia curruca). Appendix I., Appendix II.D, Appendix III.D, Table 2, Fig. 5

The Lesser Whitethroat was a dominant songbird species in the study area. In total, 2,097 individuals of Lesser Whitethroat were ringed between 1998 and 2016. The most birds (163 indiv.) were captured in 2005 and the fewest (65 indiv.) in 1998. The annual captures showed no significant trend during the years 2001-2016. The Lesser Whitethroat migration started in early August, followed by one relatively high wave until mid-September. The median date of the passage was 28 Aug. The species finished its passage in mid-October. The date of the latest capture was 12 Oct. (2004). Four birds ringed in Tömörd were recovered abroad - one each in Finland, Germany, Israel and Serbia. One individual ringed in Germany was recovered in Tömörd.

Common Whitethroat (Sylvia communis). Appendix I., Appendix II.D, Appendix III.D, Table 2, Fig. 5.

The Common Whitethroat was a subdominant songbird species in the study area. In total, 1,870 individuals of Common Whitethroat were ringed between 1998 and 2016. The most birds (184 indiv.) were captured in 2005 and the fewest (30 indiv.) in 2000. The annual captures showed a significant strong decreasing trend during the years 2001-2016. The Common Whitethroat migration started in early August, followed by one relatively high wave to the end of August. The median date of the passage was 22 Aug. The species finished the passage in early October. The date of the latest capture was 4 Oct. (2010). One bird ringed in Tömörd was recovered in Italy and one bird ringed in the Czech Republic was recovered in Tömörd.

Pallas's Leaf Warbler (Phylloscopus proregulus). Appendix I.

The Pallas's Leaf Warbler was a very rare songbird species in the study area. In total, 2 individuals of Pallas's Leaf Warbler were ringed between 1998 and 2016. The dates of the captures were 23 Oct. 2003 and 4 Nov. 2004.

Yellow-browed Warbler (Phylloscopus inornatus). Appendix I.

The Yellow-browed Warbler was a very rare songbird species in the study area. In total, 6 individuals of Yellow-browed Warbler were ringed between 1998 and 2016. The date of the earliest capture was 25 Sep. (2007) and the latest was on 3 Nov. (2008).

Wood Warbler (Phylloscopus sibilatrix). Appendix I., Appendix II.D, Appendix III.D, Table 2, Fig. 5.

The Wood Warbler was an accessory songbird in the study area. In total, 487 individuals of Wood Warbler were ringed between 1998 and 2016. The most birds (97 in- 
div.) were captured in 2012 and the fewest (3 indiv.) in 1998. The annual captures showed no significant trend in 2001-2016. The Wood Warbler migration began in early August, with a relatively high wave lasting from 7 Aug. to 20 Aug., followed by some smaller waves from the end of August to mid-September. The median date of the passage was 20 Aug. The species finished its passage at the end of September. The date of the latest capture was 24 Sep. (2012).

Common Chiffchaff (Phylloscopus collybita). Appendix I., Appendix II.D, Appendix III.D, Table 2, Fig. 5.

The Common Chiffchaff was a dominant songbird species in the study area. In total, 7,403 individuals of Common Chiffchaff were ringed between 1998 and 2016. The most birds (556 indiv.) were captured in 2004 and the fewest (100 indiv.) in 1998. The annual captures showed a significant strong increasing trend over the years 2001-2016. Migration of this species started at the beginning of September, followed by one long wave with a high peak from 28 Sep to 8 Oct. The median date of the passage was 1 Oct. The species finished its passage in early November. The date of the latest capture was 11 Nov. (2000). Two individuals ringed in Tömörd were recovered abroad: one in the Czech Republic and another in Italy. Four birds ringed abroad one each in Austria, Malta, Norway and Slovenia - were recovered in Tömörd.

Willow Warbler (Phylloscopus trochilus). Appendix I., Appendix II.D, Appendix III.D, Table 2, Fig. 5.

The Willow Warbler was a subdominant songbird species in the study area. In total, 1,370 individuals of Willow Warbler were ringed between 1998 and 2016. The most birds (233 indiv.) were captured in 2005 and the fewest (33 and 33 indiv.) in 1999 and 2016. The annual captures showed no significant trend during 2001-2016. The Willow Warbler migration started at the end of August, with a relatively high wave lasting from 24 Aug. to $11 \mathrm{Sep}$. followed by another smaller wave from 18 to $28 \mathrm{Sep}$. The median date of the passage was 9 Sep. The species finished the passage in midOctober. The date of the latest capture was 29 Oct. (2016). One individual ringed in Slovakia was recovered in Tömörd and one bird ringed in Tömörd was recovered in Poland.

Goldcrest (Regulus regulus). Appendix I., Appendix II.D, Appendix III.D, Table 2, Fig. 5. The Goldcrest was a dominant songbird species in the study area. In total, 3,812 Goldcrest individuals were ringed between 1998 and 2016. The most birds (521 indiv.) were captured in 2000 and the fewest (42 indiv.) in 2002. The annual captures showed no significant trend in 2001-2016. The species migrated from the end of September, with one obvious peak at the end of October. The median date of the passage was 25 Oct. The species probably completed its passage in mid-November. The date of the latest capture was 18 Nov. (1998 and 1999). One individual ringed in Tömörd was recovered in Italy. Two birds ringed in Russia were recovered in Tömörd.

Firecrest (Regulus ignicapillus). Appendix I., Appendix II.D, Appendix III.D, Table 2, Fig. 5.

The Firecrest was an accessory songbird in the study area. In total, 588 Firecrest individuals were ringed between 1998 and 2016. The most birds (48 indiv.) were captured in 1998 and the fewest (15 indiv.) in 2002. The annual captures showed no significant 
trend in 2001-2016. The species migrated from the end of August, with several distinct peaks from $10 \mathrm{Sep}$. to $3 \mathrm{Nov}$. The median date of the passage was 3 Oct. The species probably finished the passage in mid-Nov. The date of the latest capture was 7 Nov. (1998).

Spotted Flycatcher (Muscicapa striata). Appendix I., Appendix II.D, Appendix III.D, Table 2, Fig. 5.

The Spotted Flycatcher was an accessory songbird in the study area. In total, 630 individuals of Spotted Flycatcher were ringed between 1998 and 2016. The most birds (63 indiv.) were captured in 2012 and the fewest (10 indiv.) in 1998. The annual captures showed no significant trend during the years 2001-2016. The species migrated from the beginning of August, with several distinct peaks from 7 Aug. to 27 Sep. The median date of the passage was $30 \mathrm{Aug}$. The species finished the passage in the early October. The date of the latest capture was 15 Oct. (1998).

Red-breasted Flycatcher (Ficedula parva). Appendix $I$.

The Red-breasted Flycatcher was a rare songbird species in the study area. In total, 27 individuals of Red-breasted Flycatcher were ringed between 1998 and 2016. The most birds (5 indiv.) were captured in 2012. There were no captures in 2004, 2005, 2006 or 2014 . The date of the earliest capture was 16 Aug. (2007) and the date of the latest capture was 7 Oct. (2007).

Collared Flycatcher (Ficedula albicollis). Appendix I.

The Collared Flycatcher was a rare songbird species in the study area. In total, 82 individuals of Collared Flycatcher were ringed between 1998 and 2016. The most birds (13 indiv.) were captured in 2013. There were no captures in 1998, 1999, 2000, 2009 or 2014. The most birds were captured in August, and the date of the latest capture was 17 Sep. (2008).

European Pied Flycatcher (Ficedula hypoleuca). Appendix I., Appendix II.E, Appendix III.E. Table 2, Fig. 5.

The European Pied Flycatcher was a subdominant songbird species in the study area. In total, 1,622 individuals of European Pied Flycatcher were ringed between 1998 and 2016. The most birds (153 indiv.) were captured in 2012 and the fewest (22 indiv.) in 2005. The annual captures showed no significant trend during 2001-2016. The European Pied Flycatcher migration began in early August, with a relatively high wave lasting from 17 Aug. to 28 Aug., followed by a second smaller wave from 1 to 14 Sep. The median date of the passage was $28 \mathrm{Aug}$. The species finished the passage in early October. The date of the latest capture was 7 Oct. (2007). In autumn of the same year (2009), one juvenile male was recovered in Italy.

Bearded Reedling (Panurus biarmicus). Appendix I.

One juvenile female of this species was captured in the marsh on 12 Nov. 2012.

Long-tailed Bushtit (Aegithalos caudatus). Appendix I., Appendix II.E, Appendix III.E, Table 2, Fig. 5.

The Long-tailed Bushtit was a subdominant songbird species in the study area. In total, 1,454 individuals of Long-tailed Bushtit were ringed between 1998 and 2016. The most birds (153 indiv.) were captured in 2010 and the fewest (27 indiv.) in 1998. The annual captures showed no significant trend during 2001-2016. The Long-tailed Bushtit 
migration began in early September, followed by several small waves with a distinct peak at the end of October. The median date of the passage was 14 Oct. The species probably finished its passage in mid-November. The date of the latest capture was 7 Nov (2000).

Marsh Tit (Parus palustris). Appendix I., Appendix II.E, Appendix III.E, Table 2, Fig. 5. The Marsh Tit was an accessory songbird in the study area. In total, 383 individuals of Marsh Tit were ringed between 1998 and 2016. The most birds (50 indiv.) were captured in 2000 and the fewest ( 9 indiv.) in 1999. The annual captures showed no significant trend during the years 2001-2016. The median date of the passage was 15 Sep. The date of the latest capture was 7 Nov. (2010).

Willow Tit (Parus montanus). Appendix I.

The Willow Tit was a very rare songbird species in the study area. In total, 14 individuals of Willow Tit were ringed between 1998 and 2016. The dates or periods of the captures were as follows: 26 Sep. 2000, 2 and 26 Oct. 2004 (1-1-1 indiv.), 3 Oct. 2007 (2 indiv.), from 12 to 24 Oct. 2010 (4 indiv.), and from 3 Sep. to 19 Oct. 2012 (5 indiv.).

European Crested Tit (Parus cristatus). Appendix I.

The European Crested Tit was a very rare songbird species in the study area. In total, 2 individuals of European Crested Tit were ringed between 1998 and 2016. The dates of the captures were 17 Sep. 2007 and 30 Oct. 2011.

Coal Tit (Parus ater). Appendix I., Appendix II.E, Appendix III.E, Table 2, Fig. 5 and 6. The Coal Tit was an accessory songbird in the study area. In total, 881 individuals of Coal Tit were ringed between 1998 and 2016. The most birds (379 indiv.) were captured in 2012. There were no captures in 1998, 2003, 2011, 2013 or 2015. The annual captures showed no significant trend in the years 2001-2016. The Coal Tit migration began at the beginning of September, with a distinct wave lasting from 3 to 12 Sep., followed by another smaller wave from 23 Sep to 1 Oct. The median date of the passage was 12 Sep. The species finished the passage in mid-October. The date of the earliest capture was 9 Aug. (2012) and the date of the latest capture was 9 Nov. (2000). One bird ringed in Slovenia was recovered in Tömörd on 1 Oct. 2005.

Blue Tit (Parus caeruleus). Appendix I., Appendix II.E, Appendix III.E, Table 2, Fig. 5. The Blue Tit was a dominant songbird species in the study area. In total, 7,097 individuals of Blue Tit were ringed between 1998 and 2016. The most birds (1045 indiv.) were captured in 2004 and the fewest (69 indiv.) in 1998. The annual captures showed no significant trend in 2001-2016. The Blue Tit migration started at the end of August, with several relatively small waves from 30 Aug. to 20 Sep., followed by four stronger waves with only one distinct peak on 19 and 20 Oct. This relatively high peak was observed only in 2004 and 2008. The median date of the passage was 10 Oct. The species probably finished the passage in mid-November. The date of the latest capture was 11 Nov. (2000). Five individuals ringed in Tömörd were recovered abroad: 2 in Croatia, 2 in Serbia and 1 in Italy. One bird ringed in the Czech Republic and one bird ringed in Italy were recovered in Tömörd.

Great Tit (Parus major). Appendix I., Appendix II.E, Appendix III.E, Table 2, Fig. 5. The Great Tit was a dominant songbird species in the study area. In total, 5,755 individuals of Great Tit were ringed between 1998 and 2016. The most birds (950 indiv.) 
were captured in 2010 and the fewest (98 indiv.) in 1998. The annual captures showed no significant trend in 2001-2016. The Great Tit migration began at the beginning of September, followed by one distinct wave in October, with relatively high migration peaks from 5 to 19 Oct. The median date of the passage was 10 Oct. The species probably finished the passage in mid-November. The date of the latest capture was 16 Nov. (2000). Of the birds ringed in Tömörd, 4 individuals were recovered abroad: one each in Austria, Croatia, Serbia and Slovenia.

Eurasian Nuthatch (Sitta europaea). Appendix I., Appendix II.E, Appendix III.E, Table 2, Fig. 5.

The Eurasian Nuthatch was an accessory songbird in the study area. In total, 242 individuals of Eurasian Nuthatch were ringed between 1998 and 2016. The most birds (37 indiv.) were captured in 2012 and the fewest (2 indiv.) in 2011. The annual captures showed no significant trend in the years 2001-2016. According to the distribution of daily captures and recaptures, there were no migratory birds from other areas and the local birds remained at the study site from August to November. The daily captures were evenly distributed from August to November. The median date of the passage was 7 Sep. The date of the latest capture was 15 Nov. (2000).

Eurasian Treecreeper (Certhia familiaris). Appendix I., Appendix II.E, Appendix III.E, Table 2, Fig. 5.

The Eurasian Treecreeper was an accessory songbird in the study area. In total, 219 individuals of Eurasian Treecreeper were ringed between 1998 and 2016. The most birds (31 indiv.) were captured in 2000 and the fewest (1 indiv.) in 2011. The annual captures showed no significant trend from 2001 to 2016. The few daily captures were evenly distributed from August to mid-October. There were more captures at the end of October and in early November. The median date of the passage was 1 Oct. The date of the latest capture was 6 Nov. (2014).

Short-toed Treecreeper (Certhia brachydactyla). Appendix I, Appendix III.F

The Short-toed Treecreeper was an accessory songbird in the study area. In total, 193 individuals of Short-toed Treecreeper were ringed between 1998 and 2016. The most birds (20 indiv.) were captured in 2007 and the fewest (2 indiv.) in 2013. Daily captures were relatively high at the beginning of August and from 30 Aug to 1 Oct. The median date of the passage was $17 \mathrm{Sep}$. The date of the latest capture was 10 Nov. (2007).

Eurasian Penduline Tit (Remiz pendulinus). Appendix I.

The Eurasian Penduline Tit was a rare songbird species in the study area. In total, 60 individuals of Eurasian Penduline Tit were ringed between 1998 and 2016. The most birds (11-11 indiv.) were captured in 2000 and 2011. There were no captures in 1998, between 2002 and 2006, in 2013 or in 2015. The date of the earliest capture was 2 Aug. (2007 and 2011). The date of the latest capture was 11 Nov. (2000). One individual ringed in Tömörd was recovered in Latvia. One bird ringed in Austria was recovered in Tömörd.

Eurasian Golden Oriole (Oriolus oriolus). Appendix I.

The Eurasian Golden Oriole was a rare songbird among the captured species but was not rare in the study area. In total, 6 individuals of Eurasian Golden Oriole were 
ringed between 1998 and 2016. The date of the earliest capture was 23 Aug. (2009). The date of the latest capture was 11 Sep. (2013).

Red-backed Shrike (Lanius collurio). Appendix I., Appendix II.F, Appendix III.F, Table 2, Fig. 5.

The Red-backed Shrike was a subdominant songbird species in the study area. In total, 1,162 individuals of Red-backed Shrike were ringed between 1998 and 2016. The most birds (110 indiv.) were captured in 2004. The annual captures showed a significant moderate decreasing trend in 2001-2016. The Red-backed Shrike migration began at the beginning of August, with a relatively high peak in mid-August followed by a smaller wave in September. The median date of the passage was 19 Aug. The date of the latest capture was 11 Oct. (2008).

Great Grey Shrike (Lanius excubitor). Appendix I.

The Great Grey Shrike was a rare songbird species in the study area. In total, 31 individuals of Great Grey Shrike were ringed between 1998 and 2016. The most birds (4 indiv.) were captured in 2004. The most captures took place in October. The date of the earliest capture was 20 Sep. (2006). The date of the latest capture was 3 Nov. (2011).

Eurasian Jay (Garrulus glandarius). Appendix I., Appendix II.F, Appendix III.F, Table 2, Fig. 5.

The Eurasian Jay was an accessory songbird in the study area. In total, 250 individuals of Eurasian Jay were ringed between 1998 and 2016. The most birds (35 indiv.) were captured in 2014 and there was no capture in 1998. The annual captures showed no significant trend in 2001-2016. The peak migration period was at the end of September in 1998-2016. The most captures occurred in September.

Common Starling (Sturnus vulgaris). Appendix I., Appendix II.F, Table 2, Fig. 5.

The Common Starling was an accessory songbird among the captured species but was common in the study area. In total, 583 individuals of Common Starling were ringed between 1998 and 2016. The most birds (188 indiv.) were captured in 2016. The annual captures showed no significant trend in the years 2001-2016. The most birds were captured at the end of July and in early August. One Starling was recovered in Italy.

\section{House Sparrow (Passer domesticus). Appendix I.}

The House Sparrow was a rare songbird species in the study area. In total, 18 individuals of House Sparrow were ringed between 1998 and 2016. The most birds (8 indiv.) were captured in 2003.

Eurasian Tree Sparrow (Passer montanus). Appendix I., Appendix II.F, Appendix III.F, Table 2, Fig. 5.

The Eurasian Tree Sparrow was a dominant songbird species in the study area. In total, 4,247 individuals of Eurasian Tree Sparrow were ringed between 1998 and 2016. The most birds (784 indiv.) were captured in 2003 and the fewest (23 indiv.) in 2014. The annual captures showed a significant strong decreasing trend in 2001-2016. The most daily captures took place in the post-breeding dispersal period. The most sparrows were captured in August. In the autumn season of the same year (2002), one juvenile bird ringed in Austria was recovered in Tömörd. 
Common Chaffinch (Fringilla coelebs). Appendix I, Appendix II.F, Appendix III.F, Table 2, Fig. 5.

The Common Chaffinch was a subdominant songbird species in the study area. In total, 1,938 individuals of Common Chaffinch were ringed between 1998 and 2016. The most birds (767 indiv.) were captured in 2005 and the fewest (12 indiv.) in 1998. The annual captures showed no significant trend in 2001-2016. The Chaffinch migration started in mid-September with a distinct wave from 30 Sep. to 15 Oct., followed by three smaller waves until early November. The median date of the passage was 8 Oct. The date of the latest capture was 18 Nov. (2000). Six individuals ringed in Tömörd were recovered abroad: 5 in Italy and 1 in Croatia.

Brambling (Fringilla montifringilla). Appendix I, Appendix II.F, Appendix III.F, Table 2, Fig. 5.

The Brambling was a subdominant and irruptive songbird species in the study area. In total, 1,282 Brambling individuals were ringed between 1998 and 2016. The most birds (708 indiv.) were captured in 2005. There was no capture in 2003 or 2011 . The annual captures showed no significant trend in 2001-2016. The migration of the Brambling began in early October, with one distinct wave and two relatively high peaks between 20 and 30 Oct. The median date of the passage was 26 Oct. The date of the earliest capture was 25 Sep. (2005). One juvenile male was recovered in Poland and one in Slovakia.

\section{European Serin (Serinus serinus). Appendix I.}

The European Serin was a rare songbird species in the study area. In total, 83 individuals of European Serin were ringed between 1998 and 2016. The most birds (13 indiv.) were captured in 2005. There were no captures in 2000 or 2014. The date of the latest capture was 31 Oct (2004).

European Greenfinch (Carduelis chloris). Appendix I, Appendix II.F, Appendix III.F, Table 2, Fig. 5.

The European Greenfinch was a dominant songbird species in the study area. In total, 4,059 individuals of European Greenfinch were ringed between 1998 and 2016. The most birds (834 indiv.) were captured in 2005 and the fewest (18 indiv.) in 1998. The annual captures showed no significant trend in 2001-2016. The species migrated from early August to early November, showing frequent fluctuations in daily captures without distinct peaks. The median date of the passage was $21 \mathrm{Sep}$. The date of the latest capture was 19 Nov. (2000). Four individuals were recovered abroad - one each in Croatia, the Czech Republic, Italy and Slovenia.

European Goldfinch (Carduelis carduelis). Appendix I, Appendix II.F, Appendix III.F, Table 2, Fig. 5.

The European Goldfinch was an accessory songbird in the study area. In total, 215 individuals of European Goldfinch were ringed between 1998 and 2016. The most birds (68 indiv.) were captured in 2009. There were no captures in 1999 or 2012. The Goldfinch migration began in mid-September, with a distinct wave from 15 Oct. to 14 Nov. The median date of the passage was 21 Oct. The date of the latest capture was 16 Nov. (2000). 
Eurasian Siskin (Carduelis spinus). Appendix I.

The Eurasian Siskin was an accessory songbird in the study area. In total, 181 individuals of Eurasian Siskin were ringed between 1998 and 2016. The most birds (52 indiv.) were captured in 2010. There were no captures in 1998, 1999, 2001, 2003 2006 or 2014. The most birds were captured in the second half of October and in early November. The date of the earliest capture was 15 Sep. (2012).

Common Linnet (Carduelis cannabina). Appendix I.

The Common Linnet was an accessory songbird in the study area. In total, 168 individuals of Common Linnet were ringed between 1998 and 2016. The most birds (53 indiv.) were captured in 2002. One bird was captured each year in 1998, 1999, 2000, 2015 and 2016. The most birds were captured at the end of July and in early August. The date of the earliest capture was 28 Jul. (2002). The date of the latest capture was 5 Nov. (2005).

Common Redpoll (Carduelis flammea). Appendix I.

One juvenile bird of this species was captured in the grassland on 20 Sep. 2000.

Red Crossbill (Loxia curvirostra). Appendix I.

The Red Crossbill was a rare songbird species in the study area. In total, 8 individuals of Red Crossbill were ringed between 1998 and 2016. The date of the earliest capture was 4 Aug. (2008). The date of the latest capture was 6 Oct. (2012).

Common Rosefinch (Carpodacus erythrinus). Appendix I.

One juvenile bird of this species was captured in the grassland on 17 Aug. 2003.

Eurasian Bullfinch (Pyrrhula pyrrhula). Appendix I, Appendix II.G, Appendix III.G, Table 2, Fig. 5.

The Eurasian Bullfinch was an accessory songbird in the study area. In total, 456 individuals of Eurasian Bullfinch were ringed between 1998 and 2016. The most birds (71 indiv.) were captured in 2004, and there were no birds captured in 1998. The annual captures showed no significant trend in 2001-2016. The first birds usually arrived in the second half of October and the daily captures increased until midNovember. The date of the earliest capture was 4 Oct. (2002). The date of the latest capture was 19 Nov. (2000).

Hawfinch (Coccothrausthes coccothrausthes). Appendix I, Appendix II.G, Appendix III.G, Table 2, Fig. 5.

The Hawfinch was an accessory songbird in the study area. In total, 766 Hawfinch individuals were ringed between 1998 and 2016. The most birds (262 indiv.) were captured in 2004, and there were no captures in 1998. The annual captures showed no significant trend in the years 2001-2016. The Hawfinch migration started at the beginning of September, with one small wave until 20 Sep. followed by one strong wave with two distinct peaks from 12 to 16 Oct. and from 27 Oct to 3 Nov. The median date of the passage was 12 Oct. The date of the latest capture was 16 Nov. (2000). One female was recovered in Poland.

Yellowhammer (Emberiza citrinella). Appendix I., AppendixII.J, App III.I, Table 2, Fig. 5. The Yellowhammer was a dominant songbird species in the study area. In total, 3,267 Yellowhammer individuals were ringed between 1998 and 2016. The most birds (382 indiv.) were captured in 2003 and the fewest (8 indiv.) in 1998. The annual cap- 
tures showed no significant trend in 2001-2016. The Yellowhammer migration began at the beginning of September, followed by one strong wave until 7 Oct. with a high peak from 14 to 19 Sep. There was another smaller wave between 10 Oct. and 1 Nov. The median date of the passage was 17 Sep. The date of the latest capture was 19 Nov. (2000).

Ortolan Bunting (Emberiza hortulana). Appendix I.

One adult male of this species was captured on 22 Aug. 1998 and one juvenile bird was captured on 4 Sep. 2002.

Common Reed Bunting (Emberiza schoeniclus). Appendix I, Appendix II.G, Appendix III.G, Table 2, Fig. 5.

The Common Reed Bunting was a subdominant songbird species in the study area. In total, 1,748 individuals of Common Reed Bunting were ringed between 1998 and 2016. The most birds (209 indiv.) were captured in 2012 and the fewest (26 indiv.) in 2002. The annual captures showed no significant trend in 2001-2016. The Common Reed Bunting migration started at the end of September, followed by one strong wave until early November with a high peak from 21 to 25 Oct. The median date of the passage was 21 Oct. The date of the latest capture was 18 Nov. (2000). Four individuals ringed in Tömörd were recovered abroad: 2 in the Czech Republic and 1 each in Slovakia and Sweden. Three birds ringed in Italy, one bird ringed in Croatia, and one in the Czech Republic were recovered in Tömörd.

Corn Bunting (Emberiza calandra). Appendix I.

The Corn Bunting was an accessory songbird in the study area. In total, 118 individuals of Corn Bunting were ringed between 1998 and 2016. The most birds (51 indiv.) were captured in 2003. There were no birds captured in 2005, 2007, 2008, 2013 or 2014. The most captures (31 indiv.) took place in August 2003. The date of the latest capture was 3 Oct. (2003).

\section{DISCUSSION AND SUMMARY}

\section{Species composition and dominance}

During the period between 1998 and 2016, two of the 132 species captured were superdominant. The European Robin and the Eurasian Blackcap, with 14,377 and 13,926 captured individuals, accounted for $27 \%$ of all ringed birds. These two species were also the two most abundant species during autumn migration at the Bódva Valley Bird Ringing Station in north-eastern Hungary between 1986 and 2012, accounting for $48 \%$ of all ringed birds (Farkas et al. 2014). The heterogeneous habitats of the two study sites were similar. In Tömörd, the ten dominant species with total captures between 2,000 and 8,000, listed in order of decreasing occurrence, were Common Chiffchaff, Blue Tit, Common Blackbird, Great Tit, Eurasian Tree Sparrow, European Greenfinch, Yellowhammer, Goldcrest, Song Thrush and Lesser Whitethroat. Only the last species migrates over the Sahara (Cramp 1998). The dominant species represented 43\%. Twelve species with total captures between 1,000 and 2,000 were subdominant species, making up $17 \%$ of all ringed individuals. The three most frequent 
subdominant species were the Common Chaffinch, Dunnock and Common Whitethroat. Twenty-six species with total captures between 200 and 1,000 were accessory species, accounting for $11 \%$ of all ringed individuals. Among these, the Tree Pipit, Coal Tit and Hawfinch were the three most common species, but the Coal Tits were not caught every year in Tömörd. Two Picidae species, Eurasian Wryneck and Great Spotted Woodpecker were among the accessory species. The 29 species with total captures between 20 and 200 were the rare species, making up $1.8 \%$ of all ringed individuals. The three most frequent rare species were the Short-toed Treecreeper, Eurasian Siskin and Common Nightingale.

The 53 species with less than 20 captured individuals were very rare bird species, accounting for $0.2 \%$ of all ringed individuals. The three most common very rare species were the House Sparrow, Black Woodpecker and Long-eared Owl. The first Hungarian Eurasian Pygmy Owl to be ringed was captured in Tömörd (Bánhidi and Gyurácz 2012). The breeding area of this sedentary owl species covers the boreal forests from Northern and Central Europe to Siberia. Among the very rare bird species captured in Tömörd, two new passerines were documented in the Hungarian avifauna in 2010 and 2014. One juvenile specimen of the Red-flanked Bluetail was ringed on 12 October 2010. The breeding area of the Red-flanked Bluetail extends from Finland eastward across Siberia to Kamchatka and southward to Japan. Its breeding range is slowly expanding westwards through Finland. It occurs as a rare vagrant in several European countries outside the breeding area, e.g. in Poland, Slovakia, Italy and Cyprus. Since its wintering grounds are in the subtropical area of south-eastern Asia, its migration routes mostly avoid Central Europe. The specimens occurring during the migration period in Central and Southern Europe raise the question of whether they come from north-eastern Europe or from Siberia (Lukács and Gyurácz 2010). The Blyth's Reed Warbler was trapped and ringed on 15 August 2014. Most European vagrants of this species occur from the end of August to midNovember, when typically young birds are most likely to be recorded due to reverse migration. However, the individual captured in Tömörd was an adult bird, as identified by its plumage wear (Illés 2014). The age of this individual and its relatively early capture date suggest that this specimen probably did not arrive at the study area from the more eastern part of the breeding site but rather might belong to the northeastern European breeding population. Scarce records of vagrants may also be expected in the future, since its north-eastern European breeding population is growing (Hadarics 2015). Another avifaunistic rarity was captured in Tömörd in the spring migration period. An adult male Sardinian Warbler (Sylvia melanocephala) was captured on 5 April 1998. This was the second accepted record of this species in Hungary (Bánhidi and Gyurácz 1999).

\section{Population trends, fluctuations, migration strategies and habitat occupancy}

The number of birds ringed in the post-breeding dispersal and migration seasons in the study area around Tömörd showed considerable yearly fluctuations between 2001 and 2016. Among the fifty species analysed, ten species showed a decreasing trend, five species an increasing trend and 35 species a stable (or uncertain) trend in 
their number $\left(\chi^{2}=12.53, p=0.007\right.$. Fisher's exact test). The population index of change in captures showed a decreasing trend for the Barn Swallow, Common House Martin, Tree Pipit, Black Redstart, Whinchat, Eurasian Stonechat, Common Grasshopper Warbler, Common Whitethroat, Red-backed Shrike and Eurasian Tree Sparrow during the study period of 2001-2016. An increasing trend in the population index of change was observed for the European Robin, Eurasian Blackcap, Common Blackbird, Song Thrush and Common Chiffchaff during the study period. There was a significant difference in the population trends (decreasing, stable and increasing) regarding migration strategies (resident, short- and long-distance migrant). In the case of long-distance migrant species, the proportion of species with a decreasing population trend was $40 \%$, while among the long-distance migrants no species showed an increasing population trend. There was no difference in the population trend between resident and short-distance migrant species. The number of species with a stable population trend was higher (77\% of residents and $75 \%$ of shortdistance migrants) than the number of species with a decreasing or increasing trend. Among the resident and short-distance partial migrants there were only two species (Eurasian Tree Sparrow and Black Redstart) with a decreasing population trend. Our results are in accordance with several studies which showed trans-Saharan migrant species to have the most threatened status as compared with species with different migration strategies (Sanderson et al. 2006, Zaniewicz and Busse 2010, Szép et al. 2012). The decline of the-long distance migrants is a general ecological phenomenon in the Western Palearctic, and global climate change presumably has an important role, among other factors such as habitat change and agricultural intensification (Both and Visser 2005, Pearce-Higgins and Green 2014). The opposite trends of resident and short-distance migrant species in Tömörd are also indicative of the importance of climate change in these processes. Population dynamics are usually associated with the effects of the breeding, stopover and wintering grounds, which are affected by climate change (Morrison et al. 2013). Temperature and rainfall may affect the survival and reproduction of birds, as well as other demographic trends of the species (Rodriguez and Bustamante 2003), and climate change is a particularly important driver of bird population trends (Reif 2013). The results of our earlier study showed low temperature and rainfall levels in April, May and June to be the key determinants of reduced annual capture of first-year birds (productivity) of some shortdistance migrant (mainly intra-continental) passerines (e.g. Common Blackbird and Eurasian Blackcap), while the temperature in July was the most important climate factor for the breeding success of the long-distance migrant (Afrotropical) species, e.g. the European Pied Flycatcher in Tömörd (Gyurácz et al. 2016, Kiss et al. 2016, 2017).

The population trends showed a different pattern among species using different habitats classified according to habitat occupancy (farmland, forest and mixed, $\chi^{2}=14.01, p=0.001$. Fisher's exact test). There was a significant difference in the trends between the number of species using mainly farmland habitat and the number of species using mainly forest habitat. A decreasing population trend was noted for $42 \%$ of the species occurring in farmland habitat, while no species had an increasing trend. In the case of species which mainly occurred in forest habitats, increasing population trends were found in $22 \%$ of the species, while there was none with a de- 
creasing trend. According to the investigation based on the Hungarian common bird monitoring scheme (MMM), significant declining population trends were more common among breeding species which predominantly use farmland habitat in Hungary (Szép et al. 2012). Our annual captures and the results of MMM are similar and resemble those reported from all of Europe (BirdLife International 2017). In Hungary, the declining population trend of farmland bird species began after Hungary joined the EU in 2004. The negative changes in farmland habitats could influence birds' breeding/foraging in this type of habitat independently of their migration strategies. The increasing and stable populations of forest bird species, indicated by large number of these species showing an increasing trend or a stable number of annual captures, most likely indicates the extension of the area of Hungarian forests. Forested area increased by 7.6\% in Hungary in the years 2000-2015 (www.ksh.hu), mainly due to acacia and poplar afforestation in areas previously used for farming.

Fluctuations in the water level and water surface area are important factors determining abundance of bird populations and the structure of bird assemblages in wetland habitats (Wolters et al. 2005, Ma et al. 2010.) The water level and water surface area of the Tömörrd Marsh changed drastically between 1998 and 2008, and the marsh dried out due to scarce rainfall in 2000 and 2001. Habitat restoration in the winter of 2001 improved the water-holding capacity of the marsh. We analysed changes in the parameters of bird assemblages in this wetland area in relation to environmental factors. The number of migratory birds captured per year and the species richness, diversity and evenness of bird assemblages were correlated with the water level, water surface area and vegetation core (Gyurácz et al. 2011a). Some species, such as the Water Rail, Common Snipe, River Warbler, Savi's Warbler, Great Reed Warbler, Eurasian Reed Warbler, Marsh Warbler, Sedge Warbler and Common Reed Bunting, showed high, positive linear correlations with the water level and water surface area in the post-breeding period. Some wetland species, the Sedge Warbler, Savi's Warbler and Common Reed Bunting, as well as the total number of captured birds per year and total number of species captured per year, were clearly associated with thick marsh vegetation. More shorebirds foraged on the mudflats following the habitat restoration, especially the Jack Snipe, Common Snipe, Eurasian Woodcock, Green Sandpiper and Wood Sandpiper. During migration these species typically feed on mud- or sand-flats (Cramp 1998). According to our results, the bird species composition in the wetland habitat may have returned to pre-restoration levels and surface areas.

The Blue Tit was a dominant songbird in Tömörd and in the north-eastern Hungarian (Szalonna) study area, but we found strikingly different population dynamics patterns of Blue Tits migrating through the two study sites (Gyurácz et al. 2011b, Lukács et al. 2015). According to the population index of change in captures, there were two Blue Tit invasions in 2004 and 2008 in Tömörd. These intensive migrations could have resulted either from the reduced beech crop or the greater success of Blue Tit breeding in the Alps and Carpathians, as well as in northern areas, e.g. Poland and the Baltic region (Nilsson et al. 2006). The various species that depend heavily on the same seeds tend to irrupt in the same years; examples include Blue Tits or Great Tits, which feed heavily on beech crop (Newton 2011). Based on Helbig (2003), as well as 
Pulido and Berthold (2003), we predict that the migratory part of the partially migratory populations of the Blue Tit will decline and irruptive years in Tömörd will become rarer in response to global warming. There were also two Coal Tit invasions in Tömörd in 2010 and 2012. The majority of captured Coal Tits were immature individuals which probably originated in the Eastern Alps (Lukács and Gyurácz 2013). The number of Chaffinches, Bramblings, Hawfinches and Greenfinches ringed was highest in 2005 due to the large quantity of helianthus growing in the fields around the study area that year. The number of Eurasian Tree Sparrows ringed was highest in 2003 due to the abundance of wheat grain around Tömörd in that period.

\section{Timing of migration and habitat selection}

Capture dynamics offers a good reflection of the real intensity of daily migration dynamics (Zehnder and Karlsson 2001, Nowakowski et al. 2005). The migration curves based on the average number of individual species ringed daily between 2001 and 2016 showed that the temporal pattern of the migration of long-distance migratory species was different from that of the median- and short-distance migratory species. Birds could be classified into three distinct groups based on the migration dynamics in the study area. The first group began autumn migration from the end of July to early August and terminated it in early October. On average, the Barn Swallow, Sedge Warbler, Marsh Warbler, Common Whitethroat, Lesser Whitethroat, Thrush Nightingale, Red-backed Shrike and other long-distance migrants started their migration at the end of July or in the first half of August. Most trans-Sahara migratory birds left the study area by October. The migration of the second group commenced from the last part of August to mid-September and lasted until the end of October or early November (e.g. Winter Wren, Dunnock, European Robin, Black Redstart, Common Blackbird, Eurasian Blackcap, Common Chiffchaff and Great Tit). The third group included the short-distance or vagrant species. Their migration began at the end of September or in early October and stopped by the end of October or early November (e.g. Goldcrest and Common Reed Bunting). In the case of the longdistance migrants, earlier and more intensive migration was not only an adaptive migration strategy but also resulted from the avoidance of competition with shortdistance migrant species (Berthold et al. 2003). The dynamics of autumn migration differ considerably between adults and juveniles of some long-distance migrants. Adult warbler species representing the genus Acrocephalus and Garden Warblers migrate one week or sometimes up to three weeks earlier than young ones, and their migration is more synchronized and takes less time than that of the juveniles (Gyurácz et al. 2004, Kovács et al. 2011). The age-dependency of migration phenology is due to structural, physiological and natural selection factors (Newton 2011).

Based on the monthly data, September was the migration peak period for the Eurasian Blackcap in Tömörd. The Hungarian populations are migratory and the wintering areas are in the eastern and central Mediterranean territories. Recaptures from all over Scandinavia and Poland showed that some passing Eurasian Blackcaps migrate through the Carpathian Basin (Csörgő and Gyurácz 2009a). The timing of their autumn migration in Hungary has shifted to about two weeks later over the last 
twenty-five years (Kovács et al. 2010). October was the period peak migration for five dominant and short-distance migratory species in Tömörd: the Common Blackbird, Song Thrush, European Robin, Common Chiffchaff and Blue Tit. Despite intensive ringing activity, very few recoveries of the Common Blackbird and Song Thrush occur from north of the Carpathians; only one Polish bird was recaptured in Tömörd, suggesting that northern birds avoid the high mountains forming a barrier for them, and only a few individuals drift through. According to the recoveries of birds ringed in Tömörd and other Hungarian sites, the Hungarian Common Blackbird and Song Thrush populations winter mostly on the Apennine Peninsula (Csörgő and Gyurácz $2009 b, c)$. The autumn migration dynamics of European Robins in Tömörd and four other Hungarian ringing sites did not differ significantly from each other (Gyimóthy et al. 2011). Based on the estimated time of $10 \%$ capture, it may be concluded that juvenile birds started their migration as early as the end of August or the beginning of September, while the migration of adults began later, in mid-September or early October, at the ringing stations in Hungary. The migration dynamics of juveniles and adults did not differ significantly in the migration peak period, which lasted from the end of September to the first half of October (Gyurácz et al. 2008). On the basis of Hungarian recapture data and orientation studies in Tömörd, it may be concluded that European Robins passing through in September were primarily from Poland and Slovakia and migrated in the SSW direction. Robins breeding in north-eastern Sweden, Finland and north-western Russia passed through the study site mainly in October (Gyurácz and Csörgő 2009a). The autumn migration dynamics of Common Chiffchaffs with migration peaks at the end of September and early October in Tömörd and Ócsa (Central Hungary) were very similar. The warmer weather caused a delay in male departure dates, while it did not influence female autumn migration timing in Ócsa. Chiffchaffs show sex-dependent migration strategies with considerable protogyny in autumn (Csörgő and Harnos 2011). Common Chiffchaffs from territories to the north of the Pannonia region almost never pass through Hungary (Gyurácz and Csörgő 2009b), but a bird ringed in Norway was recaptured in Tömörd.

Our observations showed that the area around Tömörd is an important stopover site for Goldcrests migrating through our country during the autumn season. This was proved by the relatively large number of captured birds. In the Baltic region, the migration of Goldcrests lasts from early September until late October (Remisiewicz and Baumanis 1996), while the peak season in Poland is in early October. In Scandinavia, the migration of Goldcrests starts in late August and lasts into early November, with the peak period from late September to mid-October (Cramp 1998). In Hungary, its migration is significantly shorter, and lasts from late September until the first days of November. The peak migration period was in the last days of October and the first days of November at two Hungarian study sites, Tömörd and Ócsa (Gyurácz et al. 2003a). This is because Scandinavian and Baltic Goldcrests arrive in great numbers at that time (Gyurácz and Csörgő 2009c).

The autumn migration of Blue Tits in Tömörd was more similar to that of irruptive migrants (e.g. Brambling), while its migration at an East-Hungarian bird ringing site (Szalonna) was closer to the migration of obligatory migrants (e.g. Common Whitethroat). The proportions of Blue Tit juveniles were similar in Tömörd (88\%) and 
Szalonna (87\%), but there were significant differences in the fat reserves and stopover durations of birds between the two sites. More precisely, birds in Tömörd were in better condition than the birds ringed in Szalonna, since migration was more intensive in the second half of October (Lukács et al. 2015). A Polish analysis (Chruściel 2006) showed that Blue Tit migration on the southern coast of the Baltic Sea began in mid-September and lasted until the end of October. The starting date of the migration was not constant, changing from year to year in Poland and in western and northeastern Hungary, but it was usually at the beginning of the second half of August. The juveniles migrated significantly earlier than the adults. In contrast, the end of migration was relatively stable - it was most often in the last days of October, or exceptionally in the first days of November in both countries. The median passage date was at the beginning of October in Poland and Sweden, and in the first half of October or mid-October in western Hungary.

The temporal evolution of bird migration is largely influenced by temperature, air pressure, wind, precipitation and cloud formation (Newton 2011). Sedge and Reed Warblers and other long-distance migrants migrated over Hungary in August and September, taking advantage of the anticyclones which occur most intensively to the west of the Carpathian Basin or over the Carpathian Basin. The majority of migration peak days of those species were recorded during anticyclones. These weather situations ensured good conditions, with only a few clouds and a light northern wind, which facilitated the orientation and movement of these birds. The cold front of the cyclones which appeared in the Baltic region or over Ukraine also had a substantial effect on the autumn migration of some short-distance migrants, e.g. the European Robin, Eurasian Blackcap, Common Chiffchaff, Goldcrest and Blue Tit (Gyurácz et al. 2003b). One day after the cold front, large numbers of individuals were captured in Tömörd. During the cold front, a strong wind was favourable only when its direction was suitable for migration (back wind), as in that case flight did not require much energy. Moreover, birds could reach a higher migration speed and minimize migration time. The long-distance and short-distance partial migrants preferred anticyclones during their autumn migration, but there were some smaller differences in their migration patterns caused by the different behaviour of the birds, as they followed different migration strategies to minimize the time and energy of the migration (Berthold 1993). There were some records of Pallas's Leaf Warbler and Yellowbrowed Warbler in Tömörd. It is likely that most individuals of these Siberian passerines reach Europe due to the effect of Siberian cyclones. In the case of Yellow-browed Warblers, other factors (reverse migration, weather conditions, or dispersal movements) may also play an important role (Bozó et al. 2016).

During migration, the habitat selection of birds had two main goals: to ensure the energy resources required to continue the migration and to avoid predators. Both goals are fulfilled by the strategy to reach the next stopover site as well as the wintering grounds as soon as possible. The most suitable stopover site was selected by a third-level decision process including inherited and learned elements. The most important key stimuli were the vegetation structure of the site and the quality and density of the nutrient resources (Cody 1985, Fuller 2012). Among the four habitats of the study site, the marsh habitat held species such as the Barn Swallow, Sedge Warbler, 
Marsh Warbler and Eurasian Reed Warbler. The other species were located along a gradient from the forest to the grassland, in accordance with changes in habitat characteristics, as the denseness and height of the vegetation decreased. At one end of the gradient we could find the species aggregating in dense, high trees and bushes, e.g. the Redwing, Nuthatch, Treecreeper, Chaffinch, and Brambling, and at the other end were the species grouped in the heterogeneous, bushy grassland, e.g. the Whinchat, Common Whitethroat, Lesser Whitethroat, Willow Warbler, and Red-backed Shrike. The species situated between the two ends of the gradient were distributed relatively evenly, such as the Winter Wren, Common Chiffchaff, Garden Warbler and Eurasian Blackcap (Gyurácz et al. 2002, Gyurácz and Bánhidi 2008).

During their stopover, some insectivorous species, e.g. the Whitethroat and Lesser Whitethroat, chose scrubs with high sugar content for rest and feeding. Therefore, these species were grouped predominantly on more open, shrubby, grasslands that resembled the savannah wintering areas. Other insectivorous species, e.g. the Sedge Warbler and Eurasian Reed Warbler, which fed on insects and spiders, settled on plants standing in water. Therefore, these birds accumulated in watery, swampy habitats during their migration period. Among the short-distance migrant species, those wintering in the Mediterranean region (e.g. European Robin) as well as those wintering in Hungary (e.g. Brambling) were continuously present in the study area. The majority of the individuals stayed in more closed, bushy habitats. Their migration was slower and they spent more time in the area than the trans-Sahara migrants (e.g. Willow Warbler), so avoidance of predators may have played a greater role in the selection of resting and feeding sites. The forest and bushy habitats, having a denser, closed vegetation structure, provided greater safety from raptors. The Bramblings, for example, chose feeding sites (fields) with bushy surroundings over open spaces because they offered more safety against the Sparrowhawk. According to our earlier study, the migration dynamics and habitat selection of long-distance migrant species exhibited essential differences compared to the short-distance migrant species. These differences were part of an adaptive strategy which was preserved from evolutionary changes. Habitat selection during the post-breeding period varies among species, and habitat change after breeding and dispersion is a frequent phenomenon for migrating birds (Gyurácz et al. 2012). Migratory passerines usually seem to use a wider range of habitats during stopovers than in the breeding period, behaving as generalists in their habitat selection (Fuller 2012).

The results of the bird ringing project of the Tömörd Bird Ringing Station brought new information on the population dynamics, migration routes and habitat preferences of some bird species migrating over Hungary. Information on the connectivity of breeding, resting and wintering areas as well as yearly and daily numbers of populations is crucial for economic (e.g. wind farm planning), conservation (e.g. biotope survey), or epidemiological measures (e.g. control of avian influenza). As migration patterns change over time, particularly in association with factors such as climate change, continued bird ringing is important even for common species. For this reason it is crucial to discover further details about the migration strategy of birds and to learn the breeding and wintering sites of birds migrating over Tömörd. Hence, we would like to continue our research. 


\section{ACKNOWLEDGEMENTS}

We wish to express our gratitude to all those members of BirdLife Hungary who helped us in our fieldwork. Staff: Szilárd Somlai (1998-1999), János Eichardt (2000-2001), Huba Huszár (2002-2003), Alex Szabolcs (2004, 2008), Norbert Mátrai (2005), Henrietta Gabnai (2006), Éva Tarr (2007), Márton Bánhidi (2008), Zoltán Lukács (2009-2012, 2014-2016), Martin Biró (2010-2011), Péter Bánhidi (2012), Richárd Kiss (2013), Lili Orbán (2014) and Norbert Vörös (2014). Ringers: Ádám Faragó, Csaba Németh, Éva Góczán, Ferenc Magai, Gellért Bátky, Gergely Király, Géza Szentendrey, János Kiss, János Wisztercill, József Góczán, József Gyurácz, László Jánosa, László Varga, Márta Ferenczi, Mihály Lenczl, Péter Bánhidi, Péter Illés, Péter Koszorús, Péter Polovitzer, Sándor Kalmár, Sándor Tatai, Zoltán Lukács and Zsuzsanna Gyimóthy. Helpers: Adrienn, Horváth, Anna Hittaller, Anna Vartapetján, András Csuka, András Kóta, Andrea Frühwirth, Andrea Haffner, Andrea Kóródi, Andrea Ruff, Anett Krisztbaum, Ádám Tomor, Ágnes Lepold, Ágoston Cs. Tóth, Balázs Bognár, Balázs Halgas, Balázs Kovács, Bence Tóth, Bernadett Csiszár, Brigitta Keresztes, Csaba Majer, Csaba Radasics, Csaba Somogyi, Csilla Kiss, Csilla Lórincz, Dorottya Illés, Éva Mihácsy, Gábor Bedenek, Gábor Klafszky, Gábor Koszorús, Gréta Janzsó, Gréta Keresztes, Gyöngyi Tóth, Gyula Tóth, Hanna Böröcz, Imre Lendvai, Katalin Böcskör, Krisztián Szegvári, Kornél Tóth, Lídia Molnár, Lilla Lovász, Lóránt Horányi, József Haffner, Máté Bánhidi, Nándor Teket, Orsolya Horváth, Renáta Horváth, Sándor Bedenek, Sándor Gergelics, Tibor Baumgartner, Tibor Kelemen, Tibor Vizslán, Tímea Németh, Veronika Kiss, Veronika Koszorús, Virág Bódis, Zoltán Lepold and Zoltán Somogyi. We would also like to thank Zsolt Karcza for making Figure 4. The ringing work was supported by the Environmental Ministry (KAC, KÖVICE), the Scientific Board of the Savaria Campus of the University of West Hungary and the National Civil Foundation of Hungary. J. Gyurácz was supported by the Békésy Fellowship and the Hungarian Academy of Science (Regional Committee in Veszprém, MTA-VEAB). The study was partially supported by the University of West Hungary (TÁMOP 4.22-08/1-2008-0020, TÁMOP 4.2.1/B-09/1/ KONV-2010-0006, TÁMOP-4.2.2.D-15/1/KONV-2015-0023 "Climate effect"). This paper is part of the South-East European Bird Migration Network and Actio Hungarica publications.

\section{REFERENCES}

Alerstam T. 1990. Bird Migration. Cambridge University Press. Cambridge.

Bairlein F. 1997. The European-African songbird migration network: new challenges for largescale study of bird migration. The $1^{\text {st }}$ Conference of EOU, Bologna. Abstracts: 1.

Bánhidi P., Gyurácz J. 1999. A kuscmás poszáta (Sylvia melanocephala) második bizonyított elöfordulása Magyarországon. [Second record of Sardinian Warbler in Hungary]. Túzok 4 (1-2): 7-8. (in Hungarian with English Summary).

Bánhidi P., Gyurácz J. 2012. A törpekuvik (Glaucidium passerinum) első gyürüzött példánya Magyarországon. [The first ringed Pygmy Owl in Hungary]. Cinege 17: 18. (in Hungarian with English Summary).

Berthold P. 1993. Bird Migration. A general survey. Oxford University Press, Oxford. 
Berthold P. Gwinner, E., Sonnenschein, E. (Eds.). 2003. Avian Migration. Springer-Verlag, Berlin.

BirdLife International. 2017. IUCN Red List for birds. Downloaded from http://www.birdlife. org on 22/06/2017.

Both C., Visser M.E. 2005. The effect of climate change on the correlation between avian lifehistory traits. Global Change Biology 11: 1606-1613.

Bozó L., Heim W., Harnos A., Csörgő T. 2016. Can we explain vagrancy in Europe with the autumn migration phenology of Siberian warbler species in East Russia? Ornis Hungarica 24 (1): 150-171.

Busse P., Meissner W. 2015. Bird Station Manual. SE European Bird Migration Network, Bird Migration Research Station, University of Gdansk, Gdansk.

Cody L. M. (Ed.). 1985. Habitat Selection in Birds. Academic Press. London.

Chruściel J. 2006. Passage timing of the blue tits (Parus caeruleus) migrating along the southern Baltic coast. SEEN Workshop, Praha. http://www.seennet.eu/index.php?id=122 (accessed on 23.09.2014).

Cramp P. 1998. The Birds of the Western Palearctic. Oxford CD-ROM. Oxford University Press, Oxford.

Csörgő T., Gyurácz J. 2009a. Barátposzáta [Eurasian Blackcap]. In: Csörgő T., Karcza Zs., Halmos G., Magyar G., Gyurácz J., Szép T., Bankovics A., Schmidt A., Schmidt E. (Eds.). Hungarian Bird Migration Atlas. Kossuth Kiadó Zrt., Budapest. (in Hungarian with English summary). pp. 504-508.

Csörgő T., Gyurácz J. 2009b. Fekete rigó [Common Blackbird]. In: Csörgő T., Karcza Zs., Halmos G., Magyar G., Gyurácz J., Szép T., Bankovics A., Schmidt A., Schmidt E. (Eds). Hungarian Bird Migration Atlas. Kossuth Kiadó Zrt., Budapest. (in Hungarian with English summary). pp. 459-463.

Csörgő T., Gyurácz J. 2009c. Énekes rigó [Song Thrush]. pp. 504-508. In Csörgő T., Karcza Zs., Halmos G., Magyar G., Gyurácz J., Szép T., Bankovics A., Schmidt A., Schmidt E. (Eds). Hungarian Bird Migration Atlas. Kossuth Kiadó Zrt., Budapest. (in Hungarian with English summary).

Csörgő T., Karcza Zs., Halmos G., Magyar G., Gyurácz J., Szép T., Bankovics A., Schmidt A. \& Schmidt E. (Eds.). 2009. Magyar madárvonulási atlasz. [Hungarian Bird Migration Atlas]. Kossuth Kiadó Zrt., Budapest. (in Hungarian with English Summary).

Csörgő T., Harnos A. 2011. A csilpcsalpfüzike (Phylloscopus collybita) vonulásának változása 23 év alatt. [Change in migration of Common Chiffchaff during 23 years] Ornis Hungarica 19: 53-63. (in Hungarian with English Summary).

Farkas R., Huber A., Gáti E. 2014. Fészkelö és vonuló madárfajok állományainak vizsgálata a Bódvavölgyben. [A study on the populations of breeding and migrating bird species in the Bódva valley]. Directory of National Park of Aggtelek. Jósvafó. (Hungarian with English summary).

Fuller R.J. (Ed.) 2012. Birds and Habitat. Cambridge University Press, Cambridge.

Greenwood J.J.D., Baillie S.R., Crick H.P.Q., Marchant J.H., Peach W.J. 1993. Integrated population monitoring: detecting the effects of diverse changes. In: Furness R.W., Greenwood J.J.D. (Eds.) Birds as monitors of environmental change. Chapman and Hall, London. pp. 267-328.

Gyimóthy Zs., Gyurácz J., Bank L., Bánhidi P., Farkas R., Németh Á., Csörgő T. 2011. Autumn migration of robins (Erithacus rubecula) in Hungary. Biologia Section Zoology 66/3: DOI: 10.2478/s11756-011-0039-9.

Gyurácz J., Bank L., Horváth G. 2004. Studies on the population and migration dynamics of five reed warbler species in a South Hungarian reed bed. Aquila 111: 105-109.

Gyurácz J., Bánhidi P. 2008. Dynamics and spatial distribution of migratory birds. University of West Hungary. István Chernel Ornithological and Nature Conservation Society. Szombathely.

Gyurácz J., Bánhidi P., Csuka A. 2011a. Successful restoration of water level and surface area restored migrant bird populations in a Hungarian wetland. Biologia Section Zoology 66/6: 1177-1182. DOI: 10.2478/s11756-011-0132-0.

Gyurácz J., Bánhidi P., Góczán J., Illés P., Kalmár S., Lukács Z., Németh Cs., Varga L. 2016. Temperature and precipitation effects on breeding productivity of some passerines - a multivariate 
analysis of constant effort mist-netting data. Biologia Section Zoology 71/11: 1298-1303. DOI: 10.1515/biolog-2016-0149.

Gyurácz J., Bánhidi P., Gyimóthy Zs. 2008. Habitat choice and dynamics of migrating populations of the Robin (Erithacus rubecula) during the autumn migration season. Ornis Hungarica 15-16: 25-34.

Gyurácz, J., Bánhidi, P., Kóródi, A. 2011b. Post-breeding movements of Blue Tits (Parus caeruleus) in a West Hungarian stopover site. Ornis Hungarica 19: 21-29.

Gyurácz J., Bánhidi P., Németh T. Vonuló madarak élöhelyválasztása a tömördi Nagy-tavon és környékén. [Habitat selection of migrating birds at the Nagy-Lake at Tömörd and its environs]. Vasi Szemle 56 (1): 52-63. (in Hungarian with English Summary).

Gyurácz J., Csörgő T. 2009a. Vörösbegy. [European Robin]. In: Csörgő T., Karcza Zs., Halmos G., Magyar G., Gyurácz J., Szép T., Bankovics A., Schmidt A., Schmidt E. (Eds). Hungarian Bird Migration Atlas. Kossuth Kiadó Zrt., Budapest. (in Hungarian with English summary). pp. 440-442.

Gyurácz J., Csörgő T. 2009b. Csilpcsalpfüzike. [Common Chiffchaff]. In: Csörgő T., Karcza Zs., Halmos G., Magyar G., Gyurácz J., Szép T., Bankovics A., Schmidt A., Schmidt E. (Eds). Hungarian Bird Migration Atlas. Kossuth Kiadó Zrt., Budapest. (in Hungarian with English summary). pp. 521-524.

Gyurácz J., Csörgő T. 2009c. Sárgafejű királyka. [Goldcrest]. In: Csörgő T., Karcza Zs., Halmos G., Magyar G., Gyurácz J., Szép T., Bankovics A., Schmidt A., Schmidt E. (Eds). Hungarian Bird Migration Atlas. Kossuth Kiadó Zrt., Budapest. (in Hungarian with English summary). pp. 528-529.

Gyurácz J., Góczán J., Bánhidi P., Lepold Á. 2003a. Autumn Migration of the Goldcrest Regulus regulus in western Hungary. The RING 25, 1-2: 38-46.

Gyurácz J., Horváth G., Csörgő T., Bank L., Palkó S. 2003b. Influence of the macrosynoptical weather situations on the autumn migration of birds. The Ring 25 (1-2): 18-36.

Gyurácz J., Kalmár S., Baráth R. 2012. Local abundance and spatial distribution of some migratory birds during post-breeding period. Ornis Hungarica 20 (1): 50-58.

Hammer R., Harper D.A.T., Ryan P. D. 2001. PAST: Paleontological Statistics Software Package for Education and Data Analysis. Palaeontologia Electronica 4(1): 9.

Hadarics T. 2015. New species in the Hungarian avifauna in 2014. Ornis Hungarica 23(2): 156-162. DOI: 10.1515/orhu-2015-0017.

Hadarics T, Zalai T. (Eds.). 2008. Magyarország Madarainak névjegyzéke. Nomenclator Avium Hungariae. [An annotated list of the birds of Hungary]. BirdLife Hungary. Budapest. (in Hungarian with English Summary).

Helbig A. J. 2003. Evolution of bird migration: a phylogenetic and biogeographic perspective. pp. 3-20. In: Berthold, P, Gwinner, E., Sonnenschein, E. (Eds): Avian migration. Springer. Berlin.

Illés P. 2014. Új madárfaj Magyarországon, a berki nádiposzáta (Acrocephalus dumetorum). [The first record and ringed specimen of the Blyth's Reed Warbler in Hungary]. Cinege 19: 37-38. (in Hungarian with English Summary).

Kestenholz M. (Comp.). 2007. Bird ringing in science and conservation. EURING, Heteren.

Kiss Cs., Bánhidi P., Lukács Z., Kalmár S., Winkler D., Gyurácz J. 2016. A csilcsalpfüzike (Phylloscopus collybita Vieillot, 1817) populációdinamikájának vizsgálata a Tömördi Madárvártán a 2000-2014-es idöszakban. [Study of the population dynamics of Common Chiffchaff between 2000-2014 in Tömörd]. Savaria Egyetemi Központ Tudományos Közleményei XXI. Természettudományok 16: 209-220. (in Hungarian with English Summary).

Kiss Cs., Winkler D., Komlós M., Farkas R., Gyurácz J. 2017. Egyes időjárási tényezók hatása a barátposzáta (Sylvia atricapilla) költési sikerére. [Effect of meteorological factors on the breeding success of Blackcap]. Hungarian Small Game Bulletin 13: 255-266. http://dx.doi.org/ 10.17243/mavk.2017.255 (in Hungarian with English Summary).

Kovács Sz., Csörgő T., Harnos A., Fehérvári P., Nagy K. 2010. Change in migration phenology and biometrics of two conspecific species in Hungary. Journal of Ornithology 152 (2): 365-373. 
Kovács Sz., Csörgő T., Harnos A., Nagy K., Reiczigel J. 2011. A kerti poszáta (Sylvia borin) vonulási mintázatának és biometriai tulajdonságainak változása Ócsán 1984-2007 között. [Change in migration phenology and biometrics of Garden Warblers at the Ócsa Bird Ringing Station between 1984-2007]. Ornis Hungarica 19: 64-74. (in Hungarian with English Summary).

Lukács Z., Gyurácz J. 2010. A kékfarkú (Tarsiger cyanurus) elsö bizonyított elöfordulása és elsó gyürüzött példánya Magyarországon. [The first record and ringed specimen of Red-flanked Bluetail in Hungary]. Cinege 15: 13-15. (in Hungarian with English Summary).

Lukács Z., Gyurácz J. 2013. A fenyvescinege (Parus ater) öszi vonulása Tömördön [Autumn migration of Coal Tit in Tömörd]. Cinege 18: 24-27. (in Hungarian with English Summary).

Lukács Z., Farkas R., Frühwirth A., Gyurácz J. 2015. Autumn migration of blue tits (Parus caeruleus) at two Hungarian study sites. North-Western Journal of Zoology 11 (2): 225-233.

Ma Z., Cai Y., Li B., Chen J. 2010. Managing wetland habitats for waterbirds: an international perspective. Wetlands 30 (1): 15-27. DOI: 10.1007/s13157-009-0001-6.

Morrison C. A., Robinson R. A., Clark J. A., Risely K., Gill J. A. 2013. Recent population declines in Afro-Palaearctic migratory birds: the influence of breeding and non-breeding seasons. Diversity and Distributions 19: 1051-1058. doi: 10.1111/ddi.12084.

Nilsson, A.L.K., Lindström, A, Jonzén, N., Nilsson, S.G., Karlsson, L. 2006. The effect of climate change on partial migration - the blue tits paradox. Global Change Biology 12: 2014-2022.

Newton I. 2011. The migration ecology of birds. Academic Press. Elsevier Ltd. Oxford.

Nowakowski J. K., Remisiewicz M., Keller M., Busse P., Rowiński P. 2005. Synchronisation of the autumn mass migration of passerines: a case of Robins Erithacus rubecula. Acta Ornithologica 40: 103-115.

Pearce-Higgins, J.W., Green R.E. (Eds.) 2014. Birds and climate change. Cambridge University Press. Cambridge.

Pulido, F., Berthold, P. 2003. Quantitative genetic analysis of migratory behaviour. pp. 53-77 In: Berthold, P, Gwinner, E. \& Sonnenschein, E. (Eds): Avian migration. Springer. Berlin.

Rappole J. H., Jones P. 2002. Evolution of old and new world migration system. Ardea 90. (3), Special Issue: 525-537.

Rodriguez C., Bustamante J. 2003. The effect of weather on lesser kestrel breeding success: can climate change explain historical population declines? Journal of Animal Ecology 72: 793-810.

Reif J. 2013. Long-term trends in bird populations: a review of patterns and potential drivers in North America and Europe. Acta Ornithologica 48: 1-16. DOI: 10.3161/000164513X669955.

Remisiewicz M., Baumanis J. 1996. Autumn migration of Goldcrest (Regulus regulus) at the eastern and southern Baltic coast. Ring 18, 1-2: 3-36.

Sanderson F.J., Donald P.F., Pain D.J, Burfield I.J., Bommel F.P.J. 2006. Long-term population declines in Afro-Palearctic migrant birds. Biological Conservation 131(1): 93-105 doi:10.1016/j.biocon.2006.02.008.

Svensson L. 1992. Identification Guide to European Passerines. 4th ed. Stockholm.

Szentendrey G., Lövei G., Kállay Gy. 1979. Az "Actio Hungarica" madárgyürüzó tábor mérési módszerei. [Measuring methods in the bird ringing camps of Actio Hungarica] Állattani Közlemények 66:161-166. (in Hungarian).

Szép T., Nagy K., Nagy Zs., Halmos G. 2012. Population trends of common breeding and wintering birds in Hungary, decline of long- distance migrant and farmland birds during 1999-2012. Ornis Hungarica 20(2): 13-63. doi: 10.2478/orhu-2013-0007.

Tieleman I. 2007. Physiological dynamics of birds in desert, tropical and temperate environments. The $6^{\text {th }}$ Conference of EOU, Vienna. Abstract voulme: 9-10.

Wolters M., Garbutt A., Bakker J.P. 2005. Salt-marsh restoration: evaluating the success of deembankments in north-west Europe. Biol. Conserv. 123: 249-268. DOI: 10.1016/j.biocon.

Zaniewicz, G., Busse P. 2010. Like a phoenix from the ashes. The Ring 32 (1-2): 17-30.

Zehnder S., Karlsson L. 2001. Do ringing numbers reflect true migratory activity of nocturnal migrants? Journal of Ornithology 142: 173-183. 


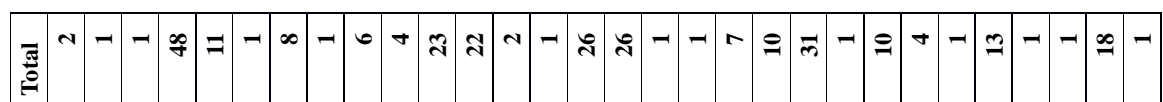

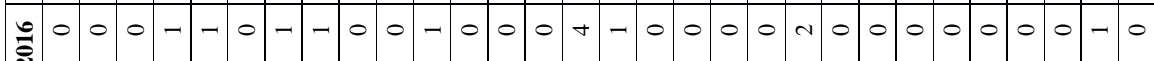

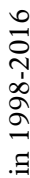

$\begin{array}{lllllllllllllllllllllllllllllll}2 & 0 & 0 & 0 & 0 & - & 0 & 0 & 0 & 0 & 0 & - & 0 & 0 & 0 & 0 & 0 & 0 & - & 0 & 0 & m & 0 & 0 & 0 & 0 & 4 & 0 & 0 & 0 & 0\end{array}$ คे

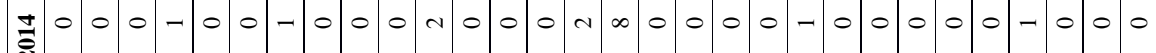

帘

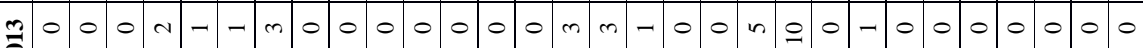

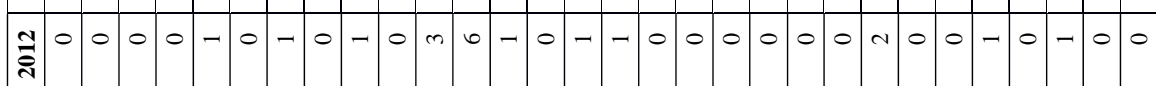

\section{(n)}

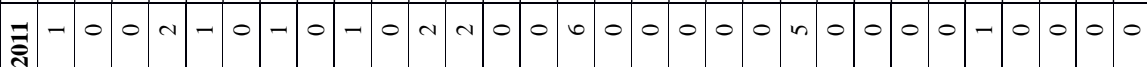

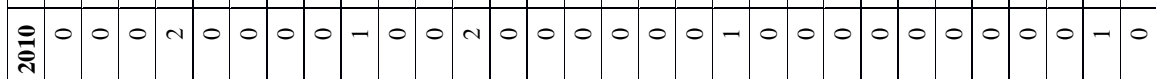

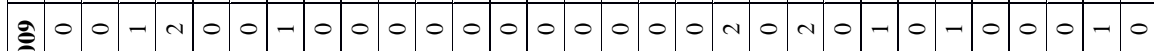
on ำ

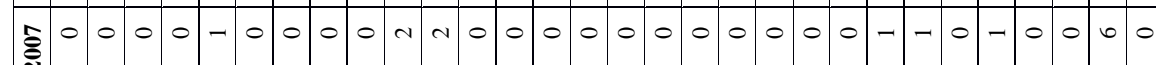

万

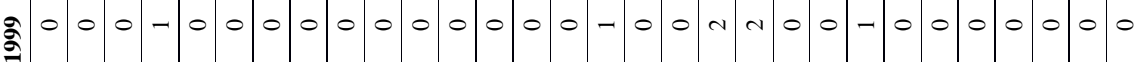

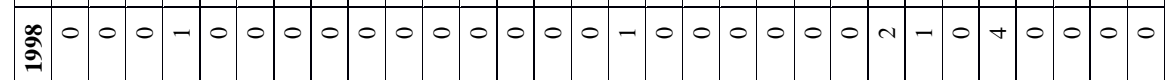




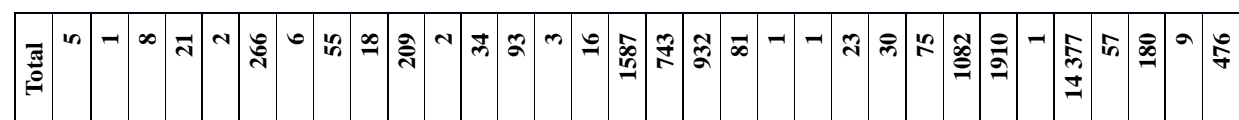

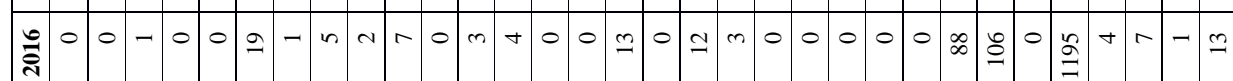

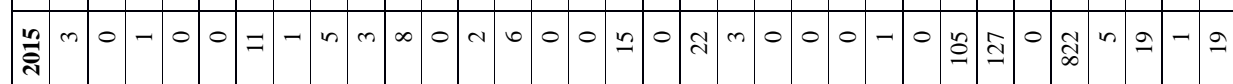

z:

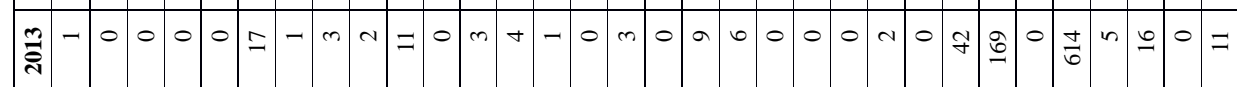



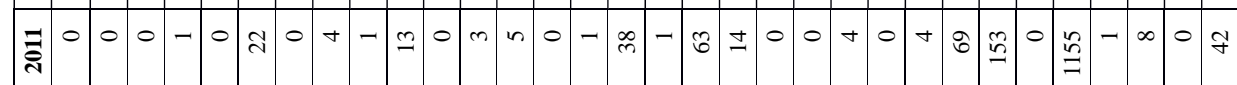

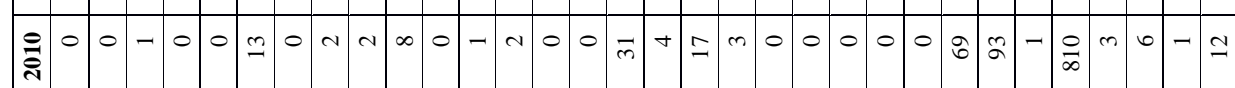



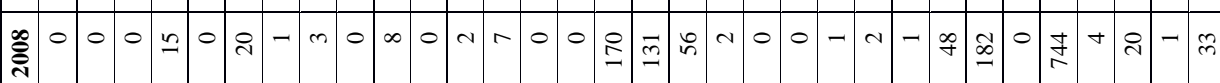

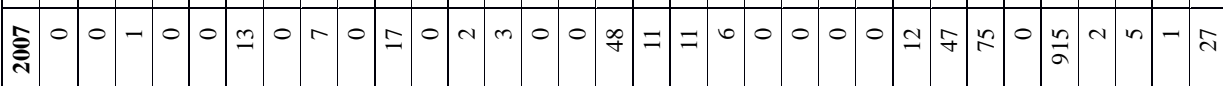

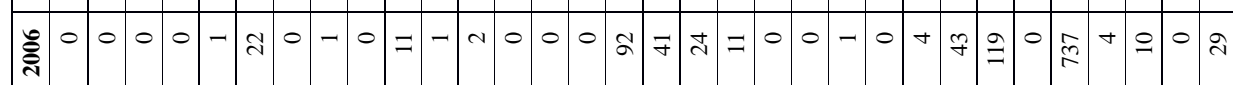

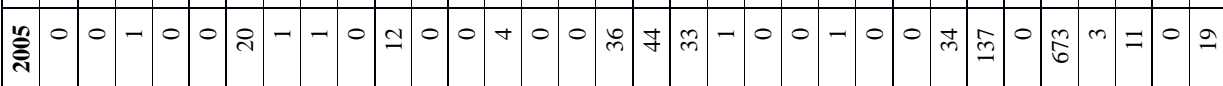

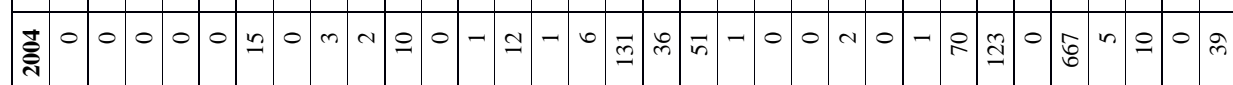

ڤิ)

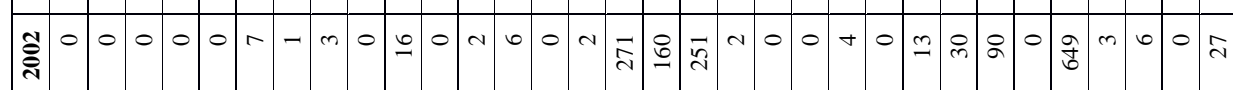

言-

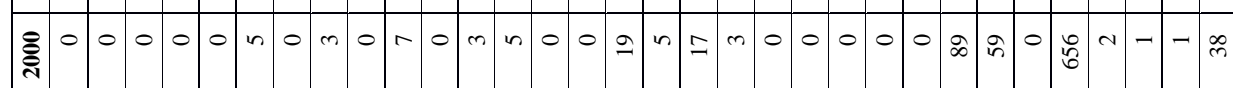

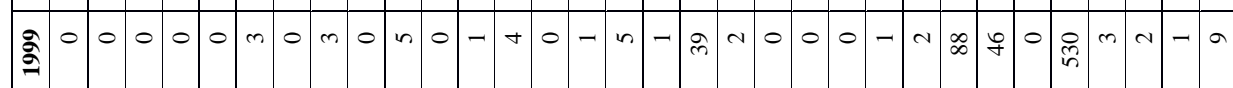

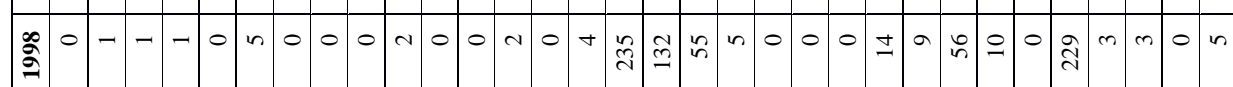

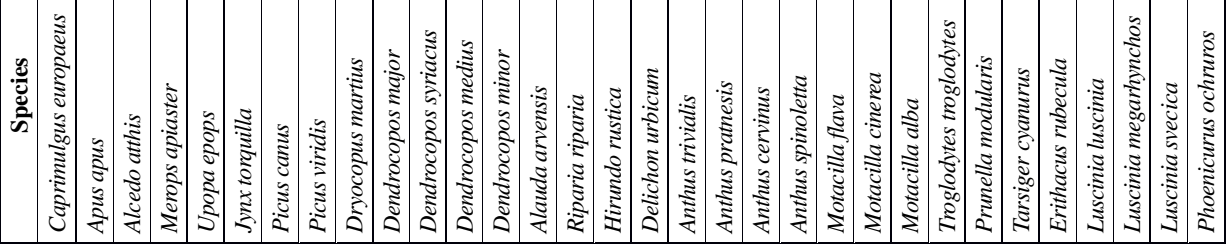




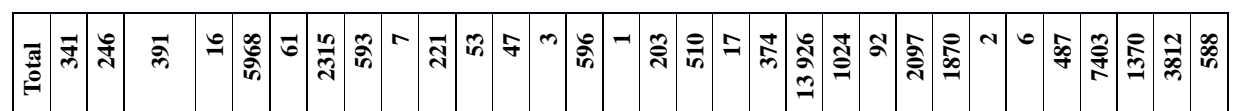

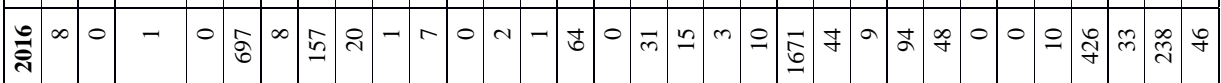

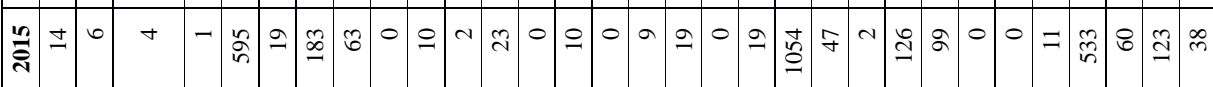

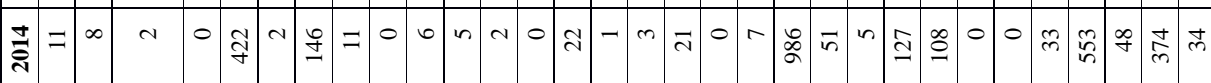

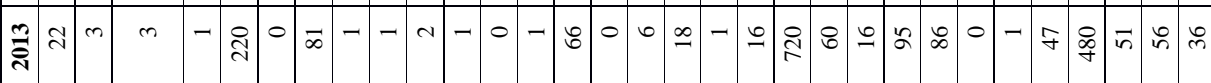

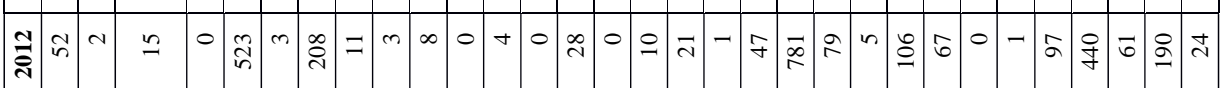

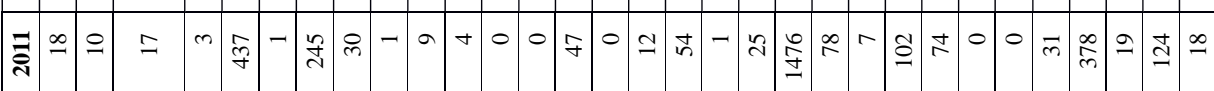

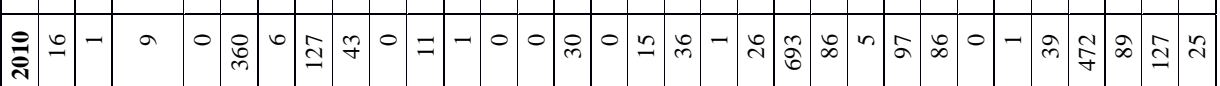

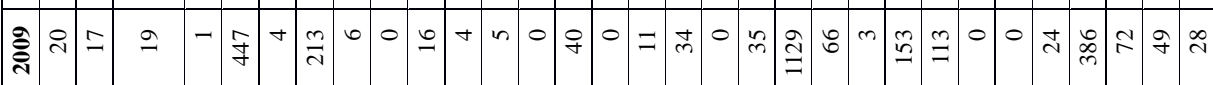

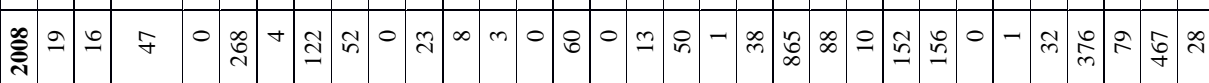

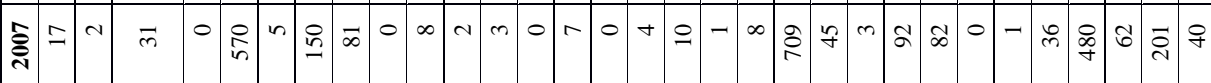

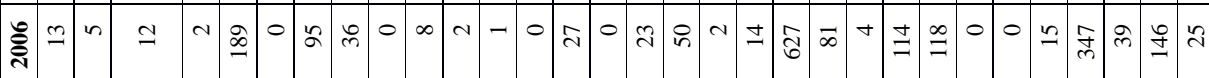

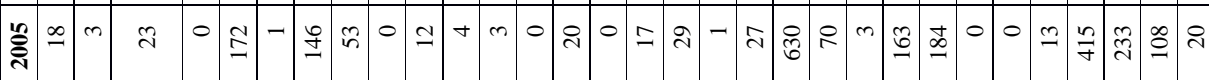

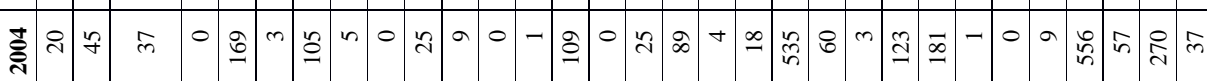

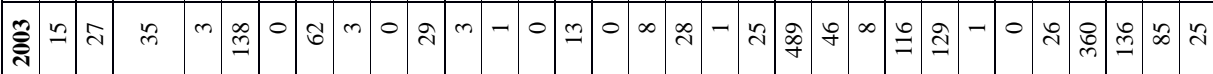

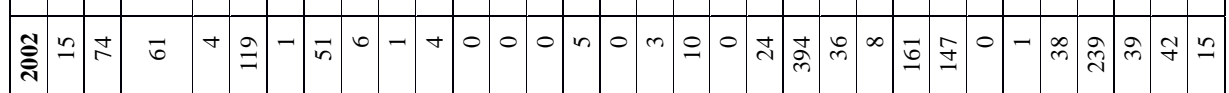

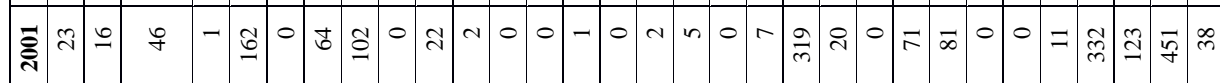

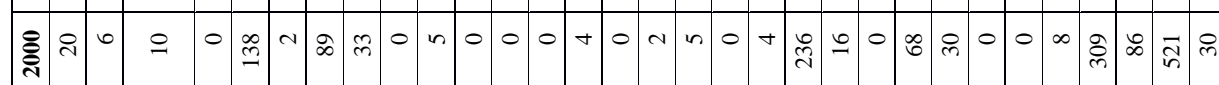

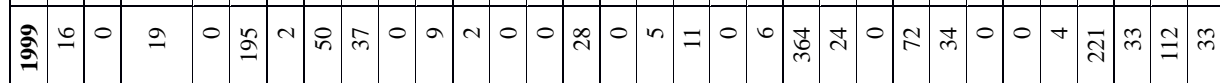

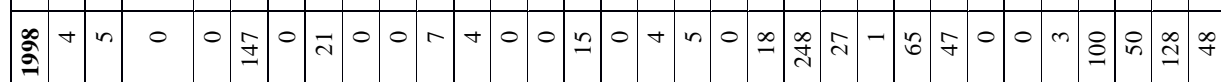

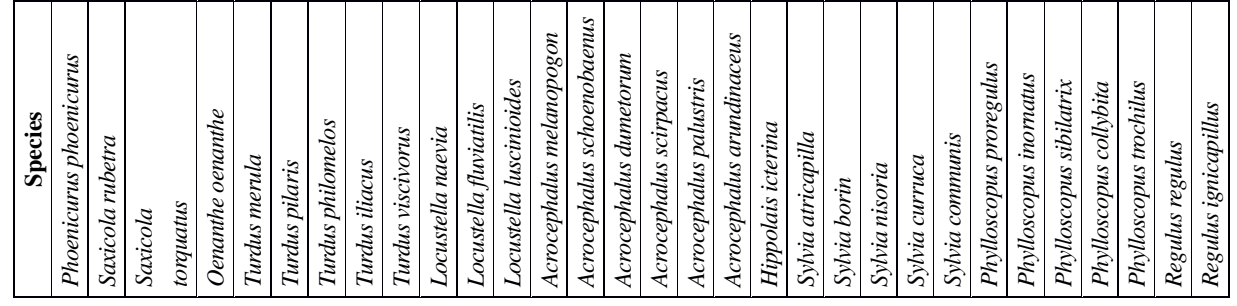




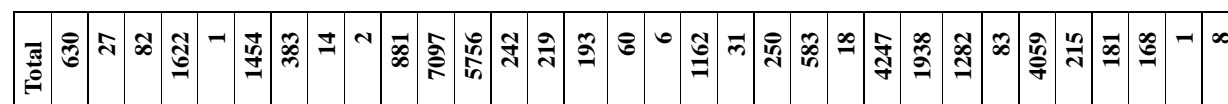

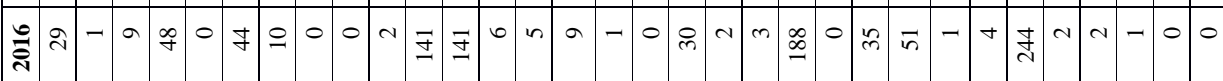

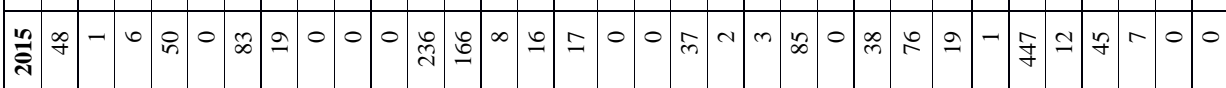

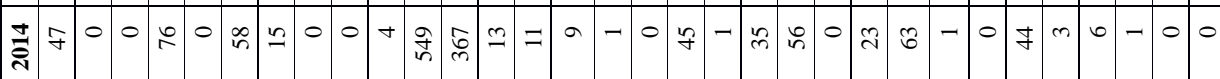

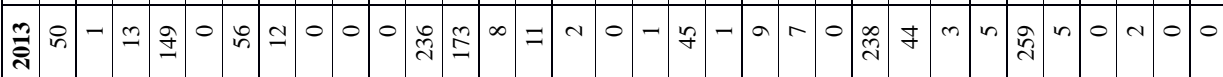

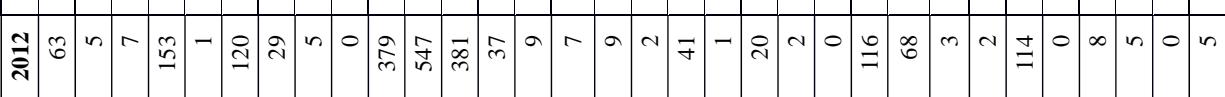

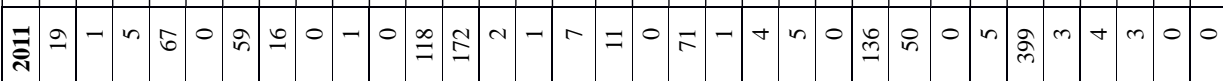

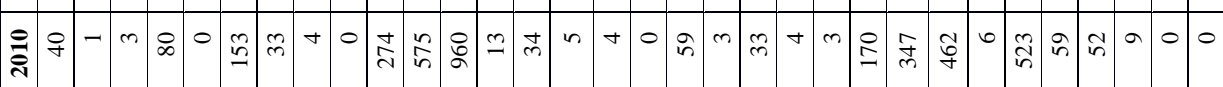

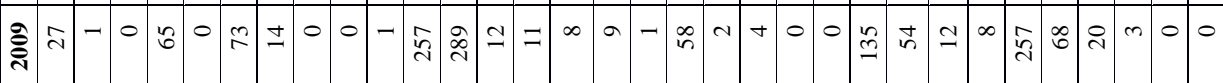
离舟

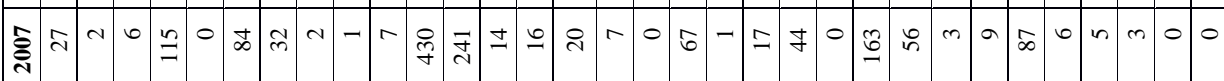

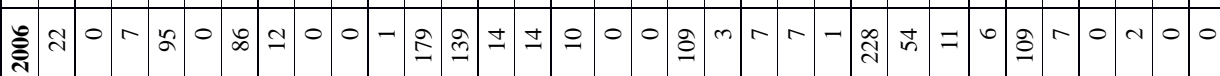

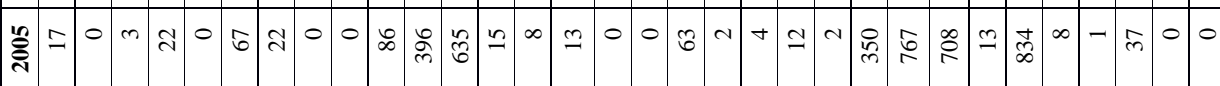

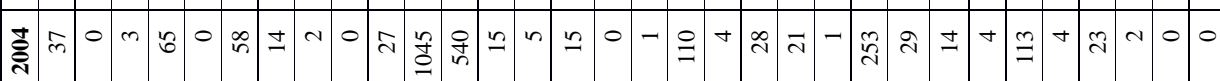
帘

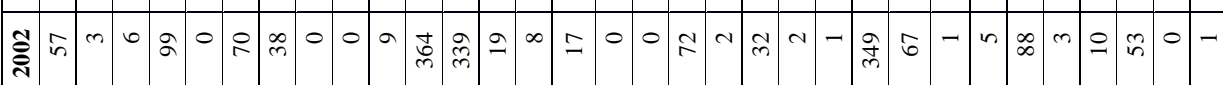
究古m m

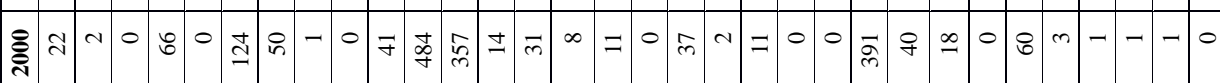

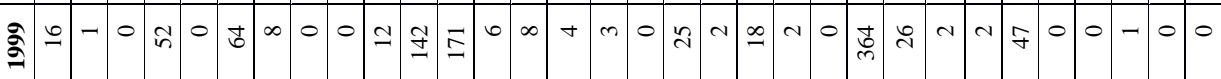

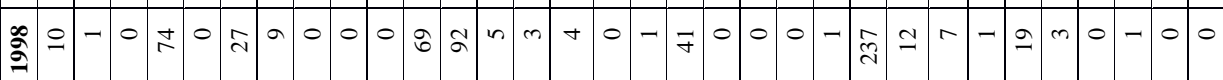

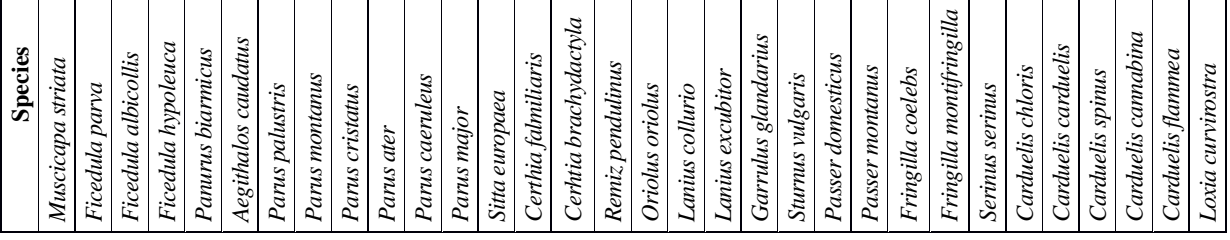




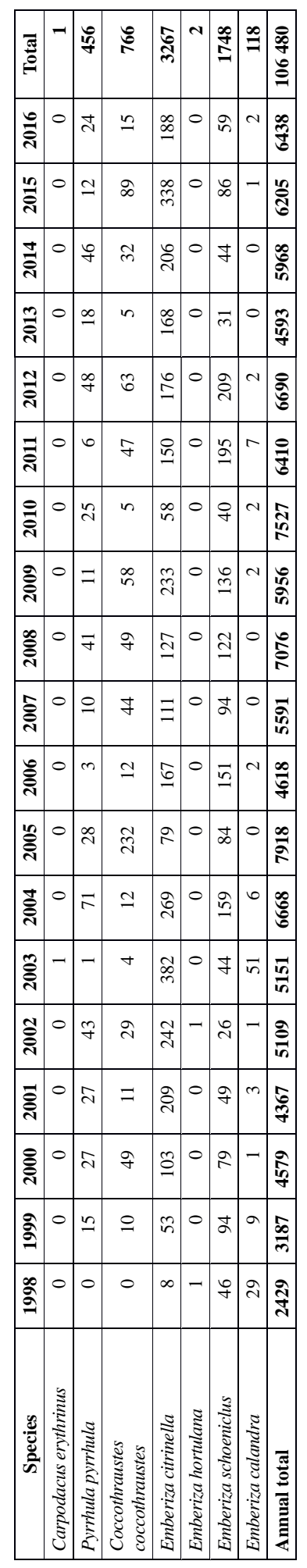


APPENDIX II - Population indices $\left(I_{x}\right)$ at the study site calculated for 2001-2016.

The regression parameters are given in Table 2.

A
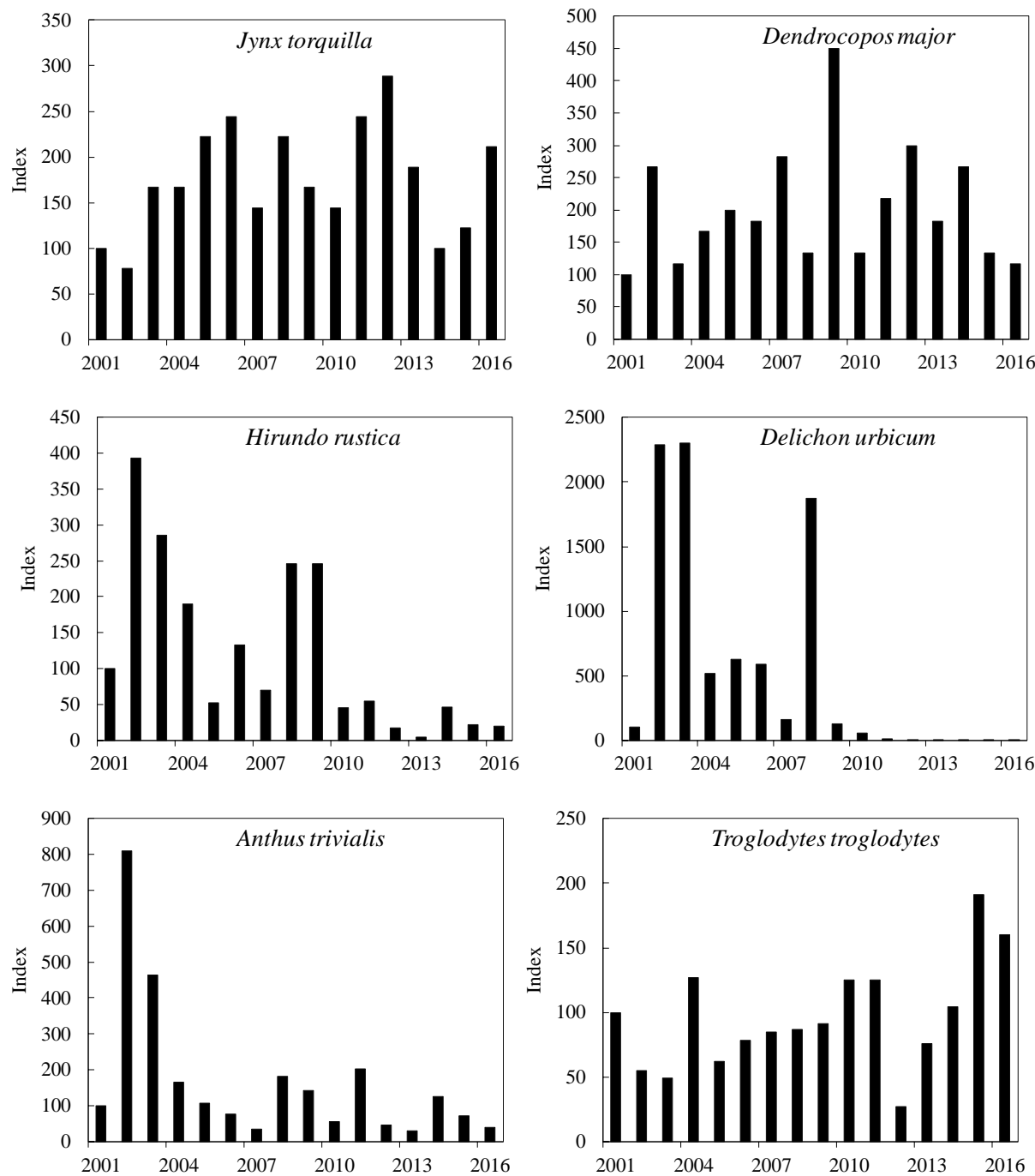

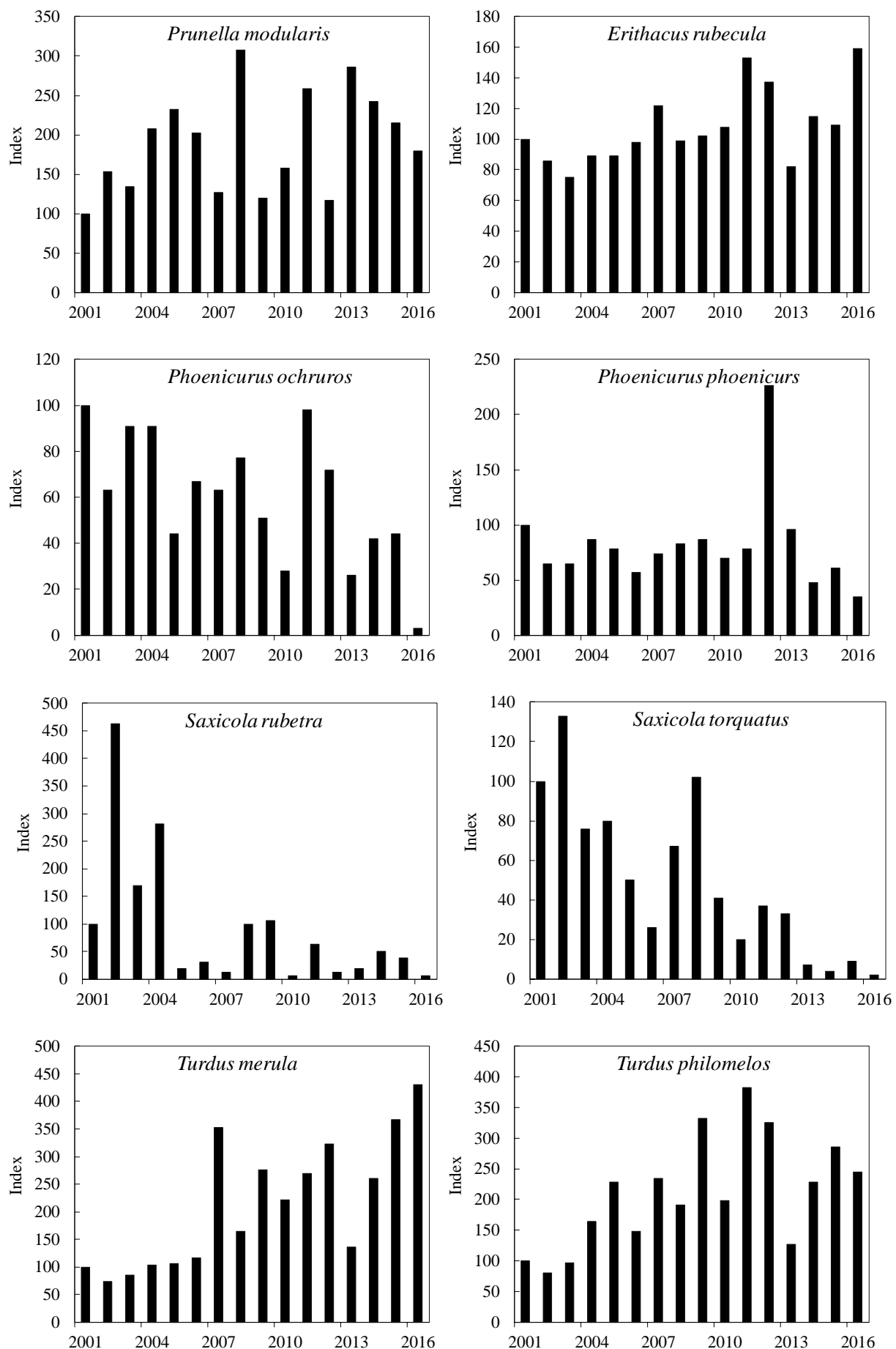
C
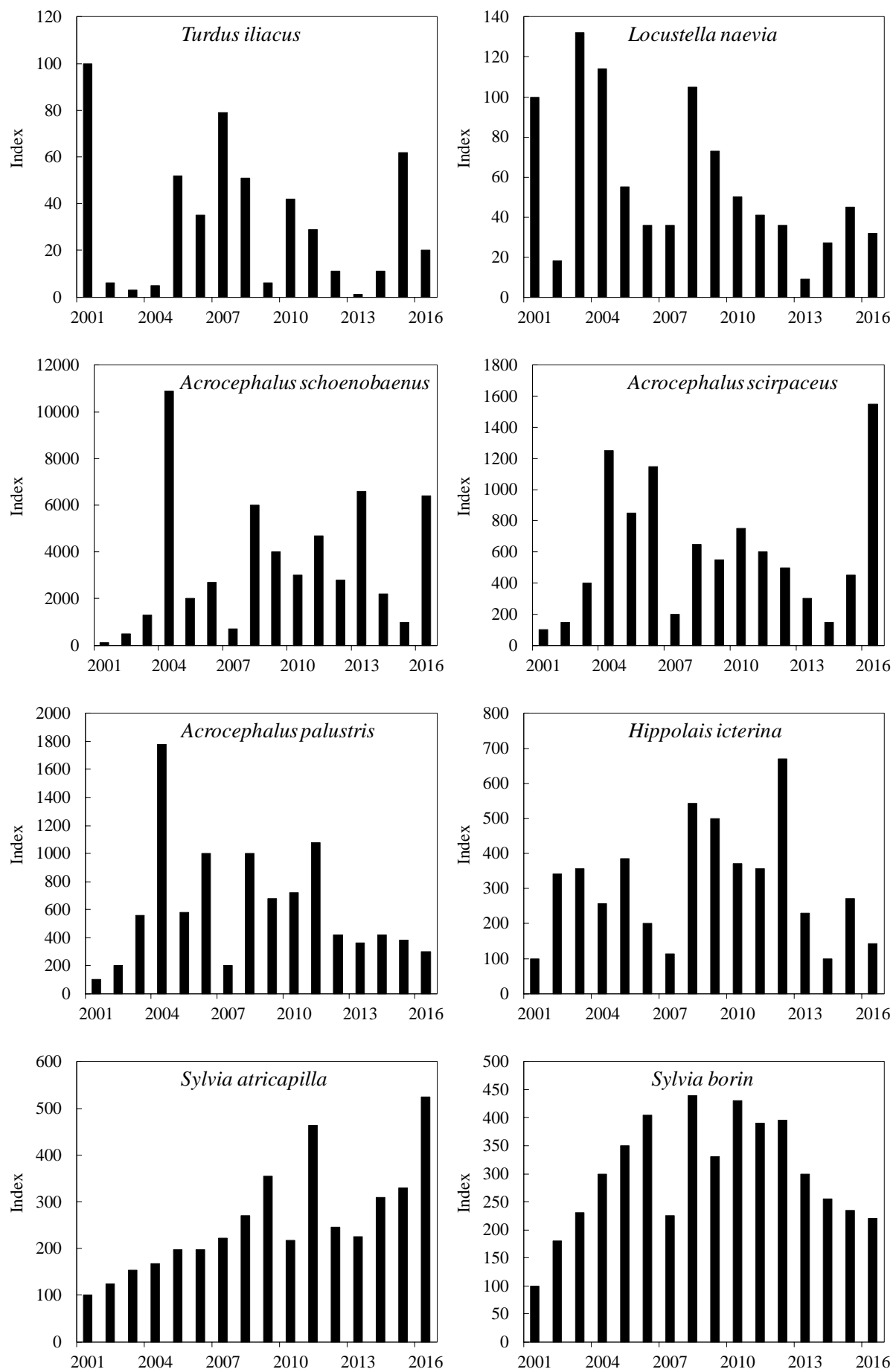
D

E
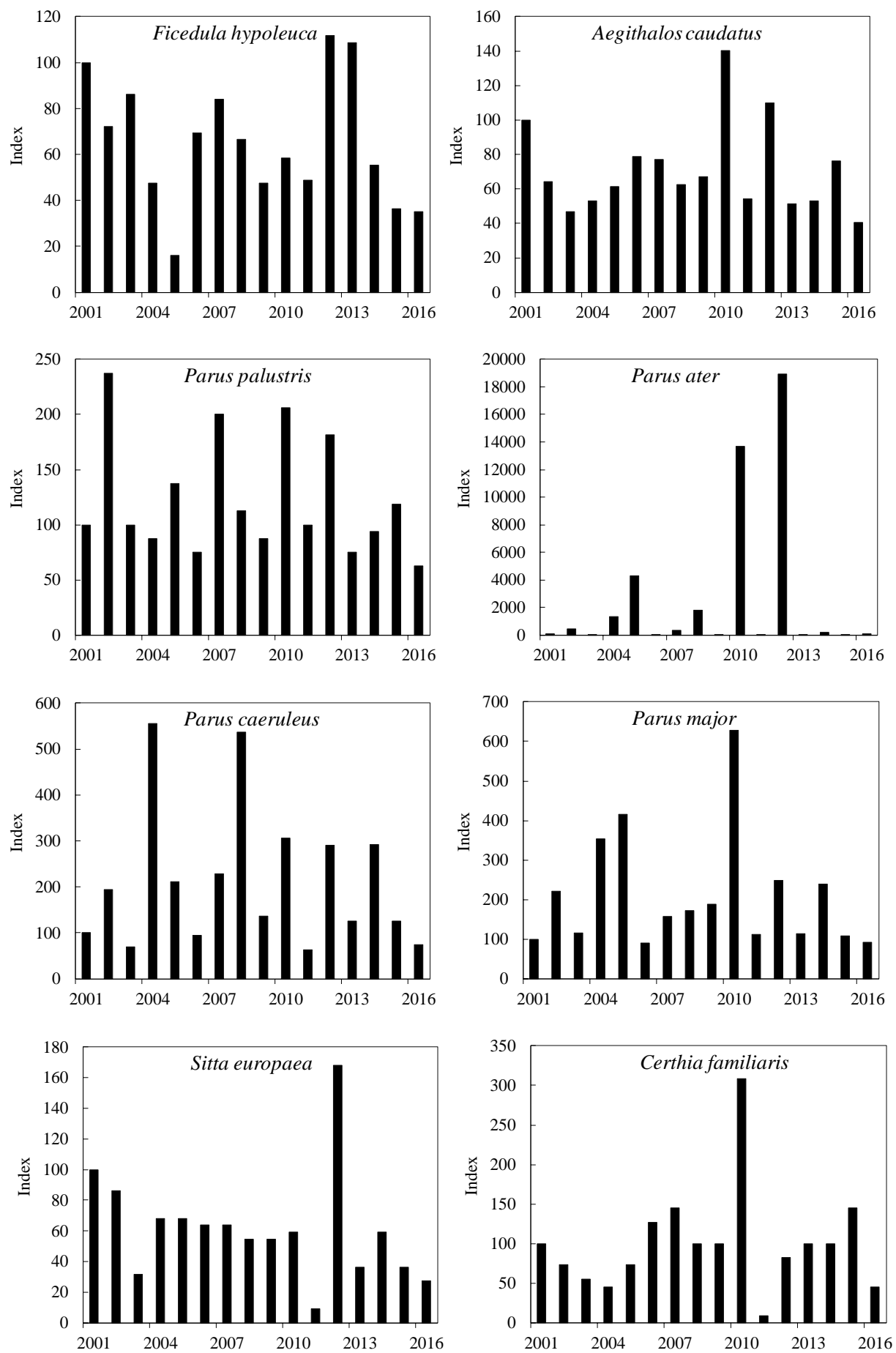

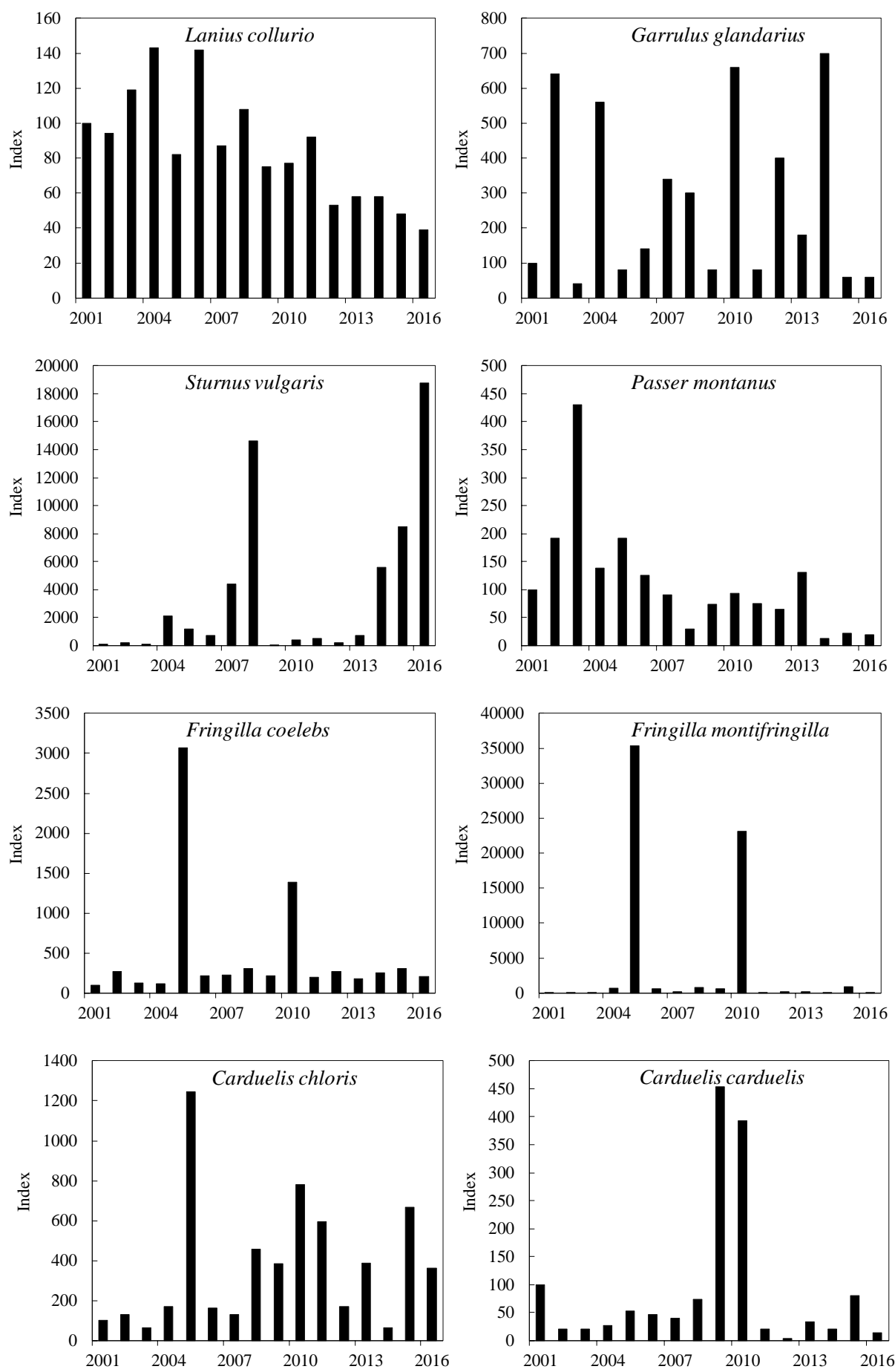
G
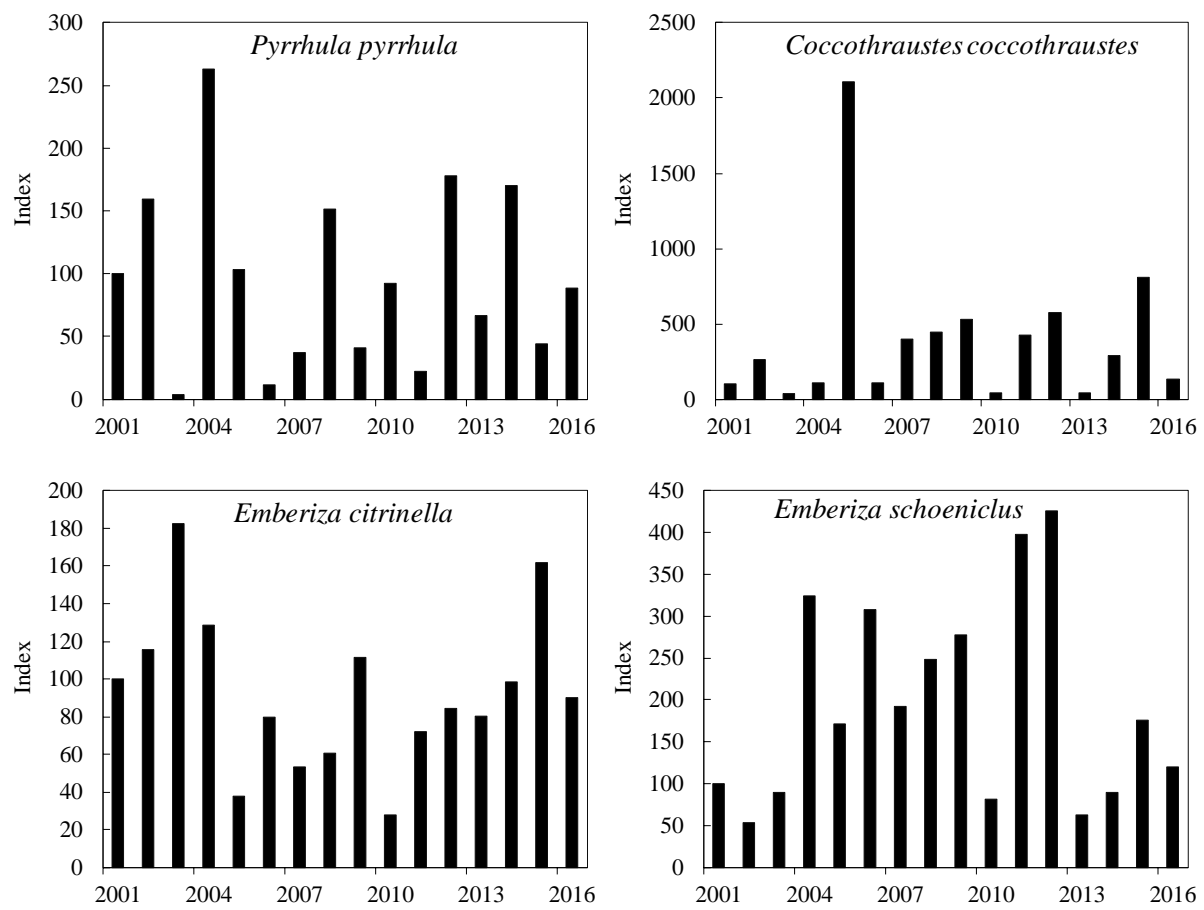
APPENDIX III - Autumn migration dynamics at the study site in 2001-2016.

Dots - total daily captures (all years), line - smoothed five-day moving average

A
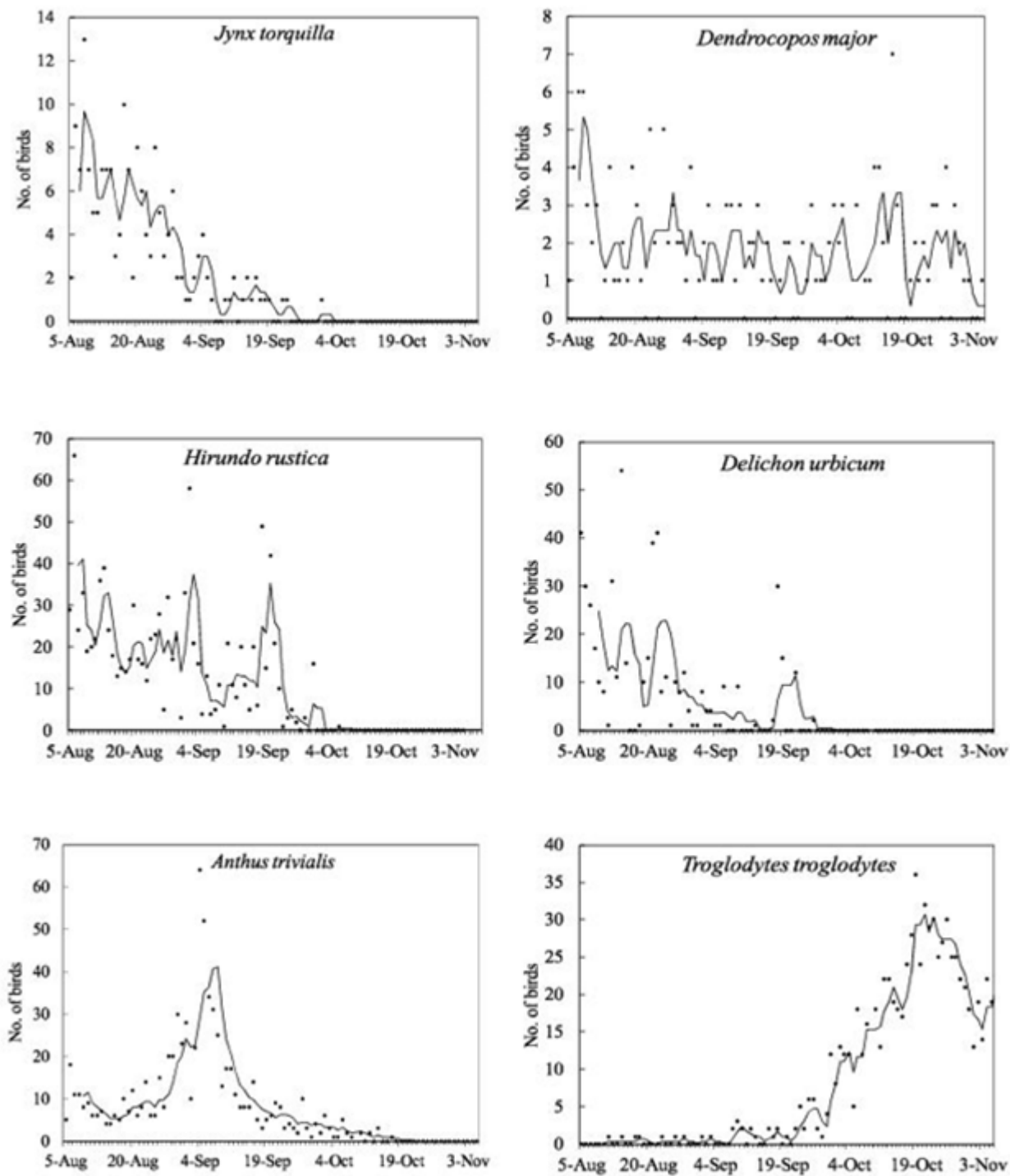
B

C
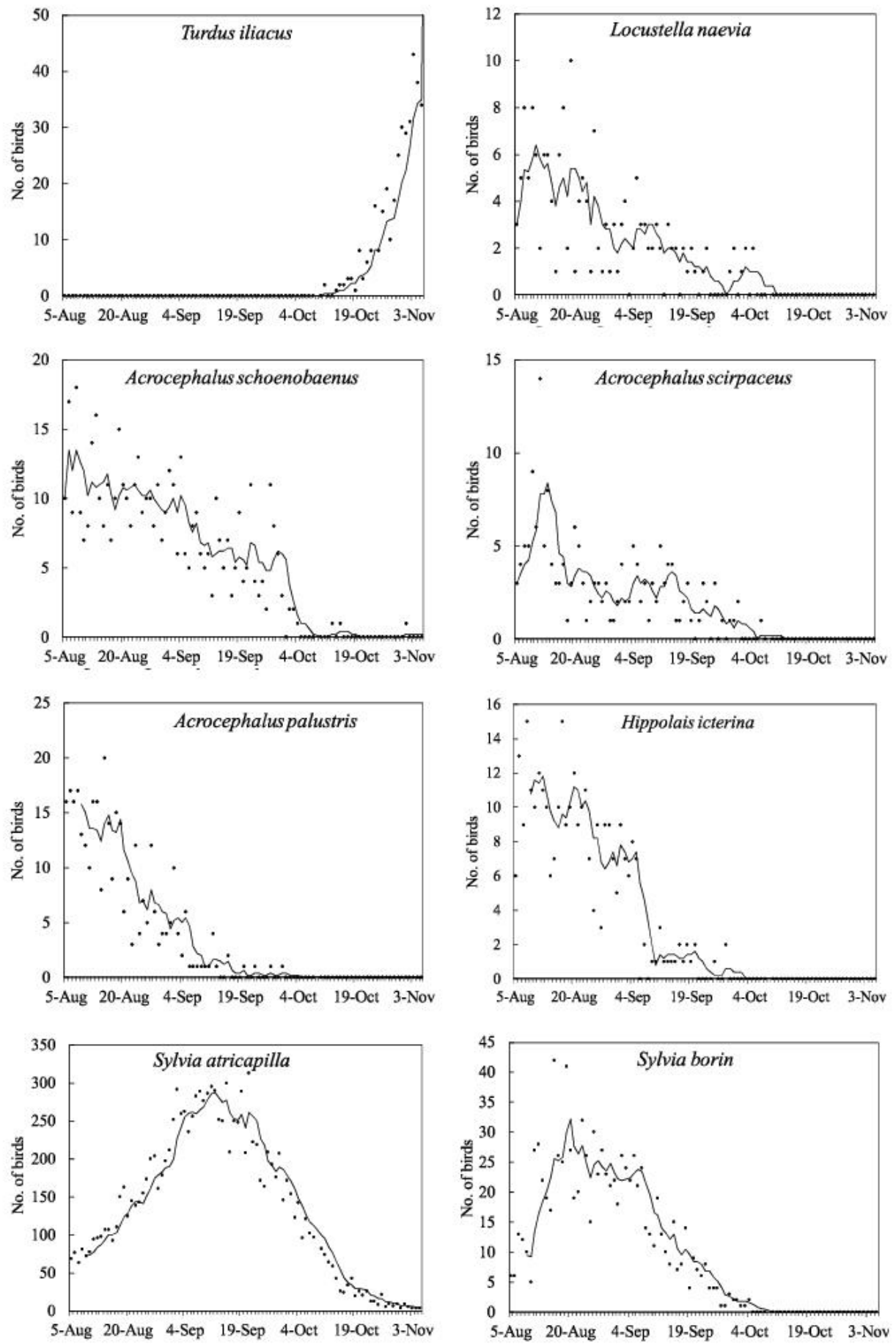
D
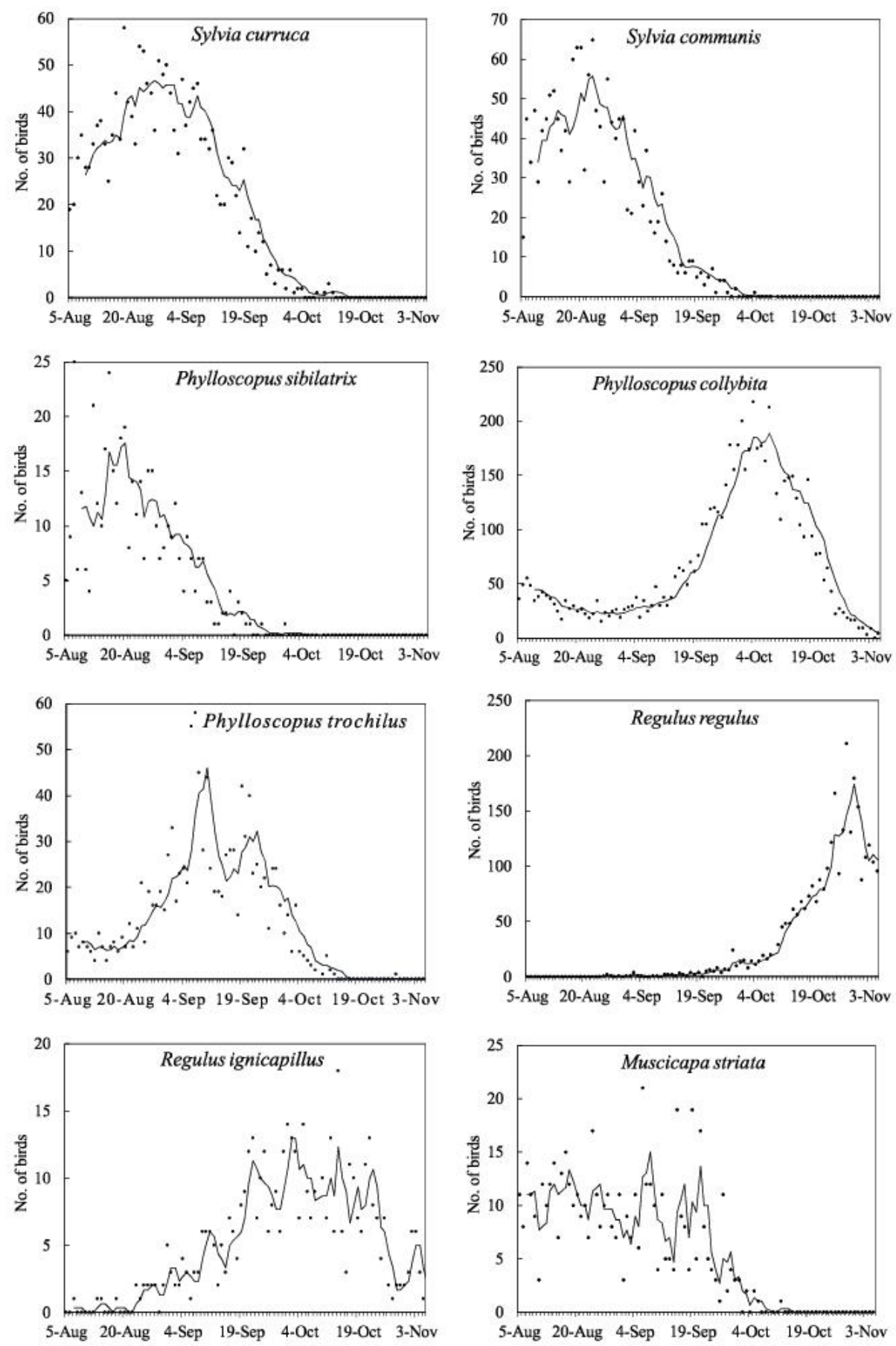
E
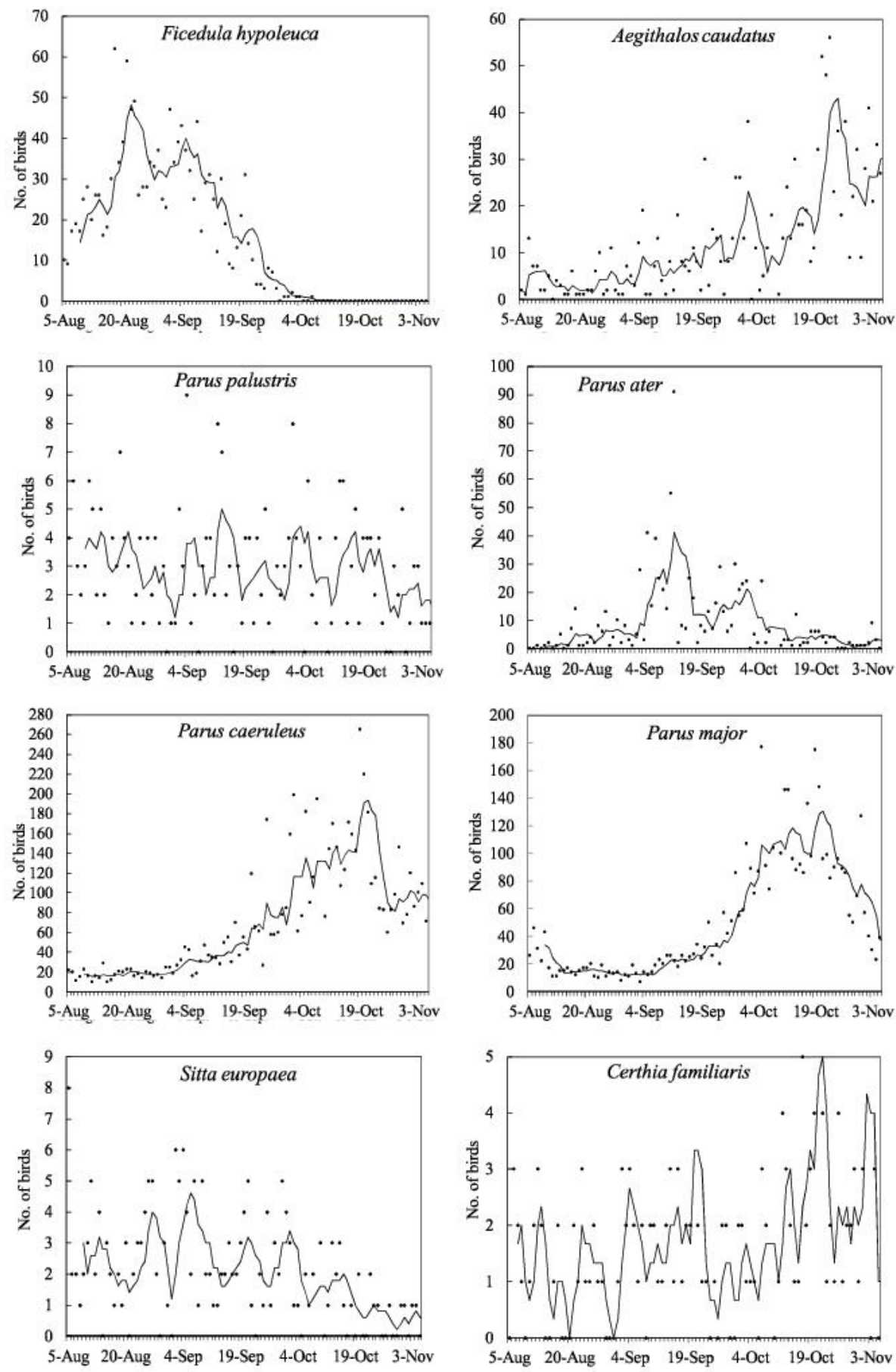


\section{F}
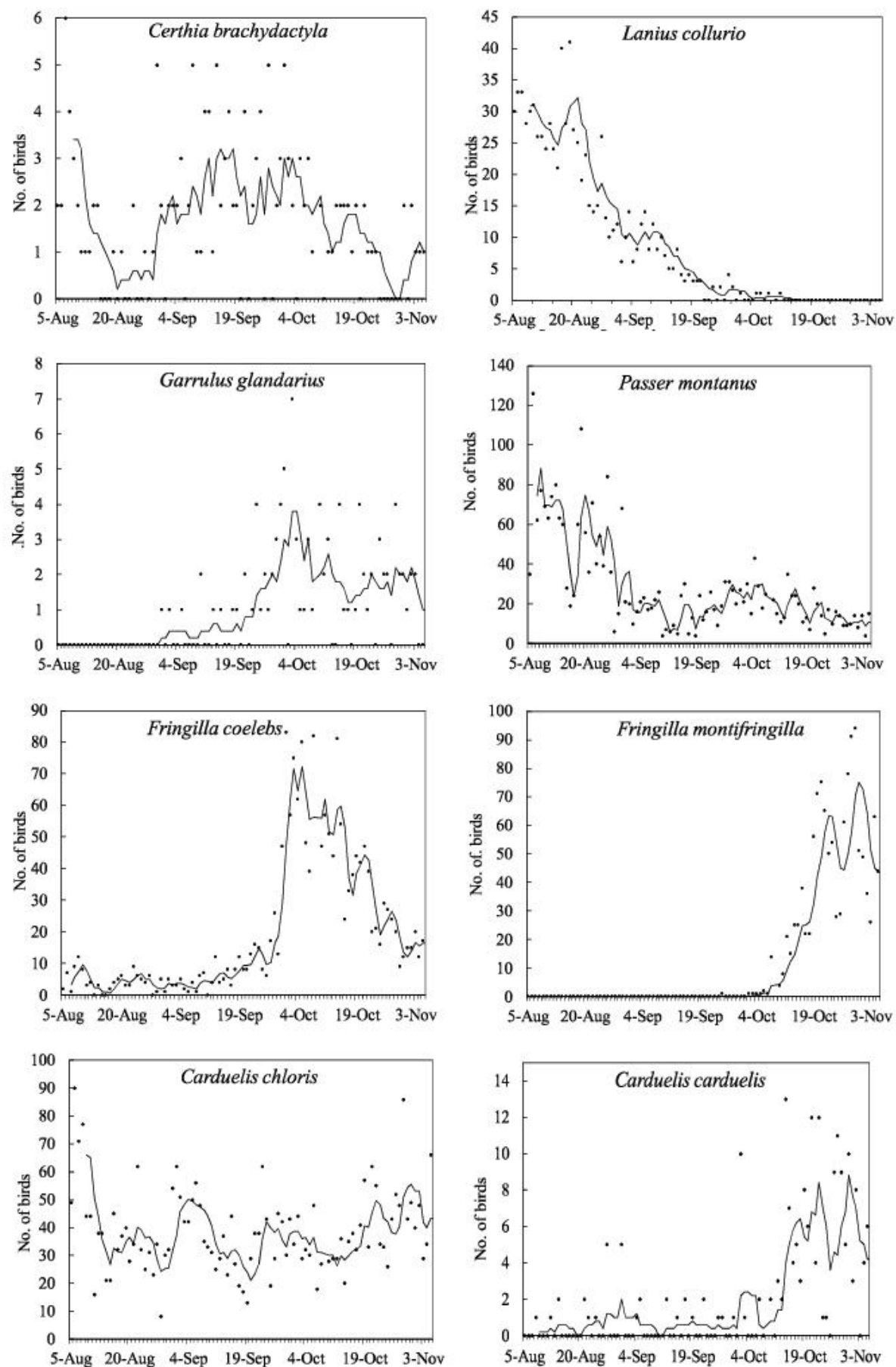
G
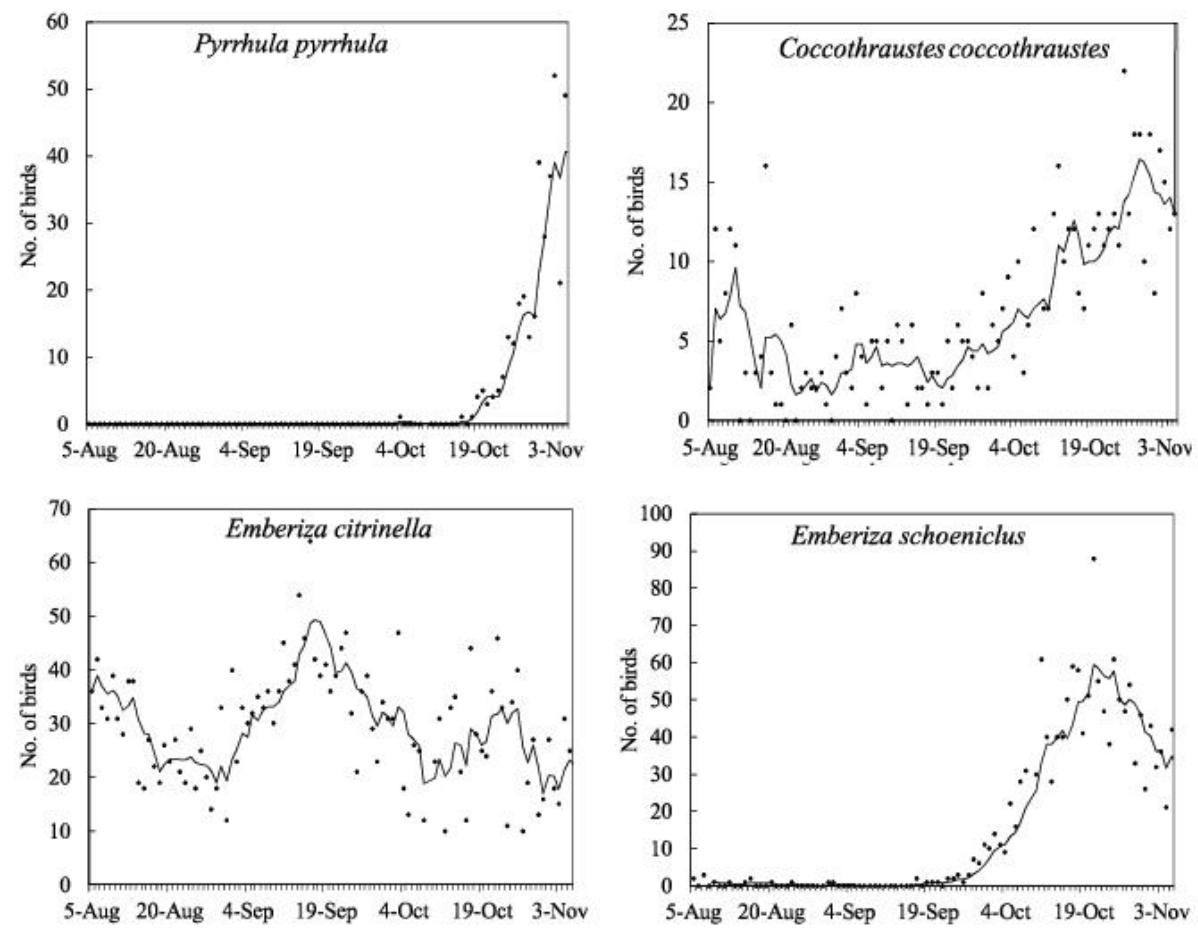